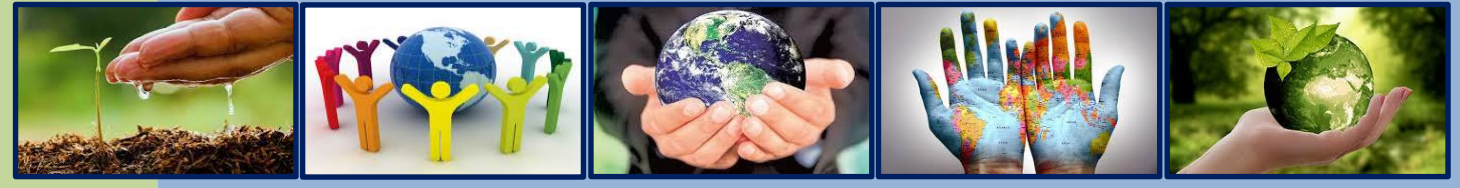

ISSN: 2298-0946, E-ISSN: 1987-6114; DOI PREFIX:10.36962/CESAJSC

JANUARY-FEBRUARY 2021 VOLUME 40 ISSUE 01

C SC SCIENTIFIC JOURNALS

\title{
THE CAUCASUS
}

ECONOMIC \& SOCIAL ANALYSIS JOURNAL OF SOUTHERN CAUCASUS

MULTIDISCIPLINARY JOURNAL

REFEREED \& REVIEWED JOURNAL

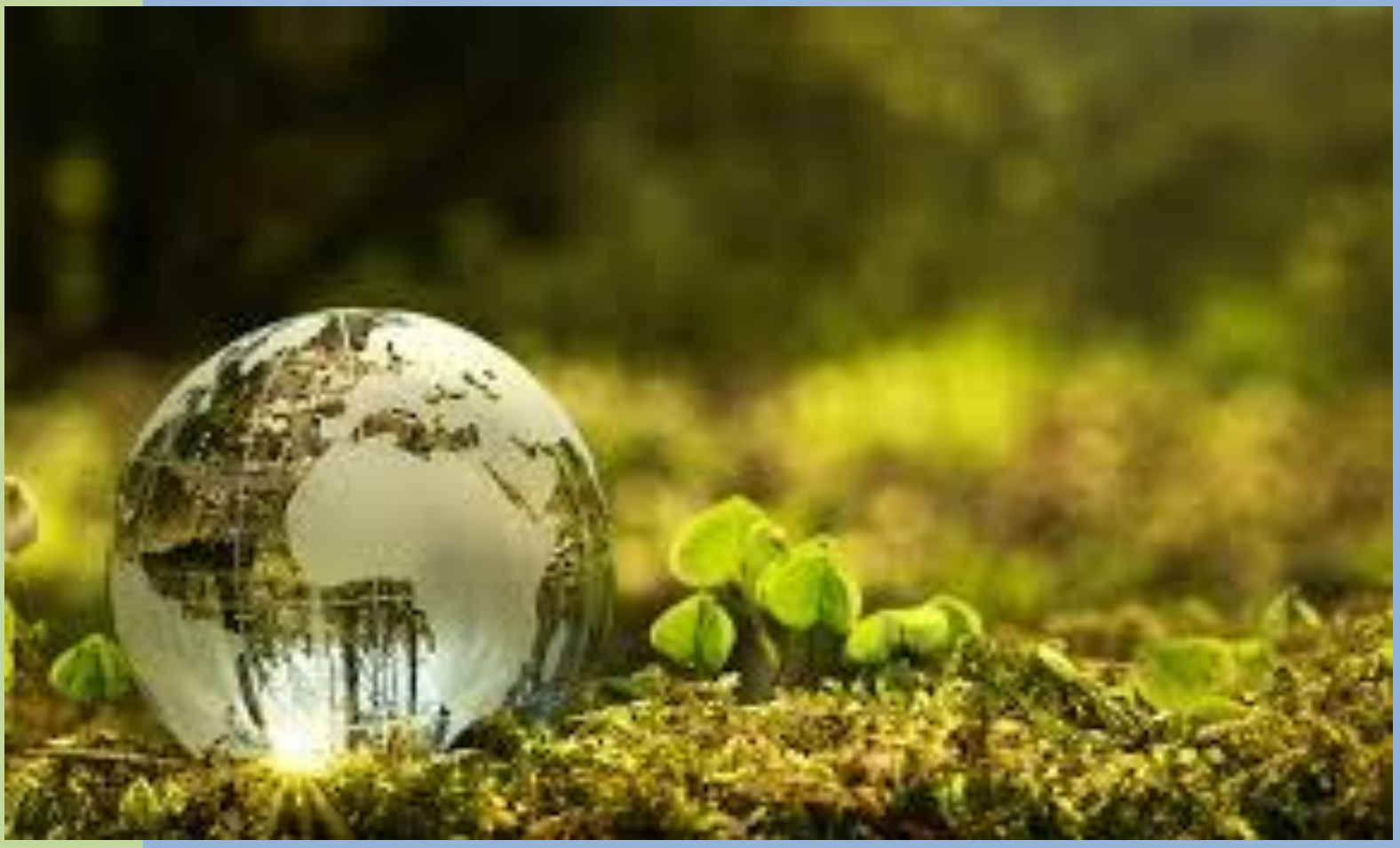

AGRICULTURAL, ENVIRONMENTAL \& NATURAL SCIENCES

SOCIAL, PEDAGOGY SCIENCES \& HUMANITIES

MEDICINE AND BIOLOGY SCIENCES

REGIONAL DEVELOPMENT AND INFRASTRUCTURE

ECONOMIC, MANAGEMENT \& MARKETING SCIENCES

LEGAL, LEGISLATION AND POLITICAL SCIENCES 
"An investment in knowledge always pays the best interest." Benjamin Franklin

JANUARY-FEBRUARY 2021 VOLUME 40 ISSUE 01

(c) SC SCIENTIFIC JOURNALS

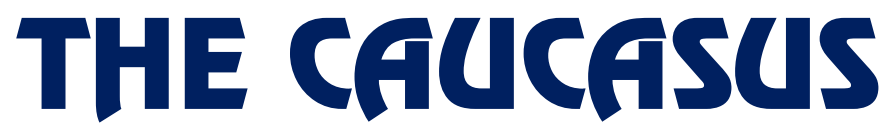

ECONOMIC \& SOCIAL ANALYSIS JOURNAL OF SOUTHERN CAUCASUS

MULTIDISCIPLINARY JOURNAL

REFEREED \& REVIEWED JOURNAL

JOURNAL INDEXING

IMPACT FACTOR OF RUSSIA ISC 2017-0.028 


\section{Editors-in-chief:}

Historical and Natural Sciences

Lienara Adzhyieva

Tubukhanum Gasimzadeh

Social, Pedagogy Sciences \& Humanities

Eka Avaliani

Medicine, Veterinary Medicine, Pharmacy and Biology Sciences

Mariam Kharaishvili

Technical, Engineering \& Applied Sciences

Nikolay Kurguzov

Regional Development and Infrastructure

Lia Eliava

Economic, Management \& Marketing Sciences

Badri Gechbaia

EDITORIAL BOARD LIST SEE PAGE 94

ISSN: 1987-6521; E-ISSN:2346-7541; DOI prefix: 10.36962/CESAJSC

OPublisher: LTD Aspendos International Academy of Medical and Social Sciences. (UK, London).

Director and shareholder: Alexandra Cuco. Lawyer. Portugal.

Deputy and shareholder: Namig Isazade. Full Professor.

(CEditorial office: 71-75 Shelton Street, Covent Garden, London, WC2H 9JQ, UK.

OTypography: LTD Aspendos International Academy of Medical and Social Sciences. (UK, London).

Registered address: 71-75 Shelton Street, Covent Garden, London, WC2H 9JQ, UK.

Telephones: +9945524170 12; +994518648894

Website: http://sc-media.org/

E-mail: gulustanbssjar@gmaill.com, sc.mediagroup2017@gmail.com; caucasusblacksea@gmail.com

CPublisher: Representation of Azerbaijan International Diaspora Center in Georgia. SCS Journals CEditorial office: 0165 Georgia. Marneuli municipality. Village Takalo.

OTypography: Representation of Azerbaijan International Diaspora Center in Georgia. SCS Journals.

Registered address: 0165 Georgia. Marneuli municipality. Village Takalo.

Telephones: +994552 4170 12; +994518 648894.

Website: http://sc-media.org/

E-mail: gulustanbssjar@gmaill.com, sc.mediagroup2017@gmail.com 
Aygül Məmmədova, Dinara Oliyeva, Nuridə Sadıqova TOSORRÜFATDAXILI YOLLARIN, SU TOSӘRRÜFATI VӘ BASQA MÜHӘNDIS QURGULARININ YERLOŞDIRILMOSI

\section{Ramilə Qəhrəmanova}

SIDERAT BITKILORIN VӘ MINERAL GÜBRӘLORIN PAMBIQ BITKISININ

MəHSULDARLIĞINA VӘ IQTISADI SəMӘRӘLILIYӘ TӘSIRI

Сергей Остроумов, Сергей Котелевцев, Евгений Криксунов

НЕКОТОРЫЕ РЕЗУЛЬТАТЫ УЧЕНЫХ МГУ И РАН ПО ВОПРОСАМ НАКОПЛЕНИЯ ХИМИЧЕСКИХ ЭЛЕМЕНТОВ В ОРГАНИЗМАХ

Арзу Миргейдарова

О СОВЕРШЕНСТВОВАНИИ МЕХАНИЗМА ПРИМЕНЕНИЯ АЛЬТЕРНАТИВНЫХ

И ВОЗОБНОВЛЯЕМЫХ ИСТОЧНИКОВ ЭНЕРГИИ В АЗЕРБАЙДЖАНЕ

Халиг Гурбанов

СТРАТЕГИЧЕСКОЕ УПРАВЛЕНИЕ БРЕНДОМ В ГЛОБАЛЬНОЙ СРЕДЕ

Садагат Ибрагимова

ФОРМИРОВАНИЕ ЛИЗИНГОВЫХ МЕХАНИЗМОВ НА ПРОМЫШЛЕННЫХ ПРЕДПРИЯТИЯХ АЗЕРБАЙДЖАНСКИЙ ГОСУДАРСТВЕННЫЙ УНИВЕРСИТЕТ НЕФТИ И ПРОМЫШЛЕННОСТИ

Балами Исмайлов

ИССЛЕДОВАНИЕ ИМИТАЦИОННОЙ МОДЕЛИ СИСТЕМЫ БЕЗОПАСНОСТИ ИНФОРМАЦИИ В СЕТЯХ ОБСЛУЖИВАНИЯ

Николай Кургузов, Людмила Кургузова, Марина Кургузова

К ВОПРОСУ ОБ УСТОЙЧИВОСТИ ФУНКЦИОНИРОВАНИЯ

МИКРОПРОЦЕССОРНЫХ РЕЛЕЙНЫХ ЗАЩИТ ЭЛЕКТРОДВИГАТЕЛЕЙ

Арзу Миргейдарова

ПУТИ ПОВЫШЕНИЯ ЭФФЕКТИВНОСТИ ИСПОЛЬЗОВАНИЯ НЕФТЯНЫХ

РЕСУРСОВ

Вахтанг Микашавидзе

ЛЕЧЕБНО-ОЗДОРОВИТЕЛЬНЫЙ ТУРИЗМ И ПЕРСПЕКТИВЫ ЕГО РАЗВИТИЯ В ГРУЗИИ 


\title{
TOSӘRRÜFATDAXILI YOLLARIN, SU TOSӘRRÜFATI VӘ BASQA MÜHӘNDIS QURGULARININ YERLOŞDIRILMӘSI
}

\author{
${ }^{1}$ Aygül Məmmədova, ${ }^{2}$ Dinara Oliyeva, ${ }^{3}$ Nuridə Sadıqova \\ 1,2,3 Yerquruluşu, torpaq və şəhər kadastrı kafedrası, ${ }^{1,2,3}$ Azərbaycan Dövlət Aqrar Universiteti. \\ ${ }^{1,2}$ Baş müəllim, ${ }^{3}$ Assisent. \\ Email: ${ }^{1}$ aygul.mammadova2018@gmail.com
}

\begin{abstract}
The article provides information on how to locate on-farm roads, water facilities and other engineering facilities.

Requirements for these facilities include:

- The creation of favorable conditions for increasing the level of land use;

- Coherent arrangement between themselves and other parts of the land use project, ensuring proper territorial organization of production;

- Compliance with technical and environmental requirements during settlement;

- It has been noted that costs of construction and operation have been minimized.
\end{abstract}

It has been stated that during the on-farm construction engineering facilities are located within the scheme of operation according to technical regulations and rules

Keywords: On-farm roads, land plot, hydraulic structures, reclamation facilities, soil erosion, engineering facilities.

\section{REZÜME}

Məqalədə təsərrüfat yollarının, su tikililərinin və digər mühəndis tikililərinin necə dizayn ediləcəyi barədə məlumat verilir. Bu strukturlar üçün tələblərə aşağıdakılar daxildir:

- torpaqdan istifadə səviyyəsinin artırılması üçün əlverişli şəraitin yaradılması;

- istehsalın düzgün təşkil olunmasını təmin edən özləri ilə torpaq istifadəsi layihəsinin digər hissələri arasında razılaşdırılmış razılaşma;

- hesablamada texniki və ekoloji tələblərə uyğunluq;

- tikinti və istismar xərclərinin minimuma endirildiyi qeyd edildi.

Təsərrüfat içi tikinti zamanı mühəndis konstruksiyalarının plan daxilində olduğu, lakin texniki qaydalara və qaydalara uyğun yerləşdiyi bildirilir.

Açar sözlər: təsərrüfatdaxili yollar, uqodiyalar, su təsərrüfatı, hidrotexniki qurguları, meliorasiya obyektləri , torpaqların eroziyası, mühəndis təchizatı obyektləri

Müasir dövrümüzdə bazar iqdisadiyyatı yeni yaranan təsərrüfat münasibətlərini və formalarının müqayisəli şəkildə effektliyini müəyyənləşdirərkən təsərrüfatın iqdisadi cəhətcə daha əlverişli formaları seçilməsinə imkan verir.Prinsipçə bu günə qədər mövcud metodik materiallardan istifadə edilməklə günün reallığından yaranan yeni təsərrüfat-forma münasibətlərini tələblərinə uyğunlaşdıraraq mükəmməlləşdirilib. Həmin qiymət rayonunda yaranmış kənd təsərrüfatı yerlərinin ümümi, beçərilən kənd təsərrüfatı bitkilərinin fərdi qiymət gösdəriciləri müəyyənləşdirilmişdir. Bu iqdisadi qiymətlər əsasında təsərrüfat daxilində yayılan muxtəlif təyinatlı təbii-təsərrüfat yerləri aid olduqları keyfiyət qrupları üzrə əsasən məhsuldarlıq 
və differensial qəlir göstəriciləri tərtib edilmiş kartoqramda ayrı-ayrı konturlar üzrə öz əksini tapmişdır.

Kənd təsərrüfatı təyinatlı müəssisələr burda istisna təșkil etmir. $\mathrm{Bu}$ cür müəssisələrin daxili təşkili onları başqa müəssisə və idarələrdən fərqləndirən aşağıdakı xüsusiyyətlərə malikdir:

1. Bu cür təsərrüfatların torpaq sahələri məkan bazası və əsas istehsal vasitələri rolundan çıxış edir.

2. Bu təsərrüfatların torpaq sahələrinə həm kənd təsərrüfatı yerləri-uqodiyalar (əkin, çoxillik əkmələr, örüşlər və biçənəklər), həm də qeyri-kənd təsərrüfatı sahələri (meşə zolaqları, yollar, tikinti altı və.s) daxildir.

3. Kənd təsərrüfatı müəssisələrinin torpaq sahələrinin daxili təşkilinə torpaqla ayrılmaz bağlı olan obyekt və uqodiyaların problemlərinin kompleks həlli daxildir.

4. Təsərrüfatdaxili yerquruluşunun obyektlərinə ancaq kənd təsərrüfatı istehsalı ilə məşğul olan kənd təsərrüfatı müəssisələri daxildir.

Ona görə də təsərrüfatdaxili yerquruluşu və ya ərazinin təsərrüfatdaxili təşkili torpağın əsas istehsal vasitəsi kimi daxili təşkilindən və torpaqla bilavasitə əlaqəsi olan istehsal vasitələrini düzgün yerləşdirmək üçün obyektiv zəruriyyətdir. Burada əsas məqsəd torpaqlardan səmərəli istifadə və onun mühafizəsindən ötrü təşkilatı-ərazi şəraitinin yaradılmasıdır.

Müasir dövrdə təsərrüfatdaxili yerquruluşu aşağıdakı məsələləri həll etməlidir:

- kənd təsərrüfatı istehsalını həyata keçirmək məqsədi ilə fiziki və hüquqi şəxslərin torpaqdan səmərəli istifadəsinin təşkili;

- kənd təsərrüfatı yerlərinin (uqodiyaların) yaxşılaşdırılması, yeni torpaqların mənimsənilməsi, torpaqların bərpası və konservasiyası, pozulmuş torpaqların rekultivasiyası, torpaqların eroziyadan, bataqlıqlaşma, şorlaşma, şorakətləşmə, istehsal tullantıları, radioaktiv və kimyəvi maddələrlə çirklənmədən mühafizəsi, torpaqların bərpası və digər tədbirlər kompleksinin işlənməsi.

Ümumiyyətlə, təşkilati-təsərrüfat nöqteyi nəzərdən, ərazinin təsərrüfatdaxili təşkili-müxtəlif mülkiyyət formalı kənd təsərrüfatı müəssisələrinində torpaqlardan, texnika və insan əməyindən səmərəli istifadəni və torpaqların münbitliyini artırılmasını təmin edən istehsalın ərazi təşkilindən ötrü tədbirlər sistemidir.

Təsərrüfatdaxili yerquruluşu zamanı mühəndis təchizatı obyektləri torpaq istifadəçiliyinin ərazisində yerləşdirilir. Bu obyektlərə aiddir:

- təsərrüfatdaxili yollar;

- meliorasiya obyektləri: nohurlar, su anbarları, kanallar, limanlar, suvarma şəbəkəsi və.s);

- $\quad$ su təminatı obyektləri;

- eroziyaya qarşı əsas obyektlər (hidrotexniki qurğular, meşə zolaqları və s.).

Yəni torpaq yerlərindən istifadənin yaxşılaşdırması ilə bağlı problemlərin həllinə əhəmiyyətli dərəcədə təsir göstərən bu cür mühəndiz təchizatı obyektlərinin yerləşdirilməsi aparılır. Bu obyektlərin yerləşdirilməsi kompleks şəkildə həyata keçirilir. Mühəndis təchizatı obyektləri iki qrupa bölünür:

- $\quad$ xətti (yollar, meşə zolaqları);

- sahəvi (suvarilan, qurudulan).

$\mathrm{Bu}$ obyektlərin yerləşməsinə aşağıdakı tələblər qoyulur:

- torpaqlardan istifadənin səviyyəsini artırmaq üçün əlverişli şəraitin yaradılması;

- istehsalın düzgün ərazi təşkilini təmin edən öz aralarında və torpaq istifadəçiliyinin layihəsinin başqa hissələri arasında razılıqlı yerləşmə;

- yerləşmə zamanı texniki və təbiəti mühafizə tələblərinə əməl olunması; 
- Onaların qurulmasına və istismarına çəkiləcək xərclərin minumuma endirilməsi.

Təsərrüfatdaxili yerquruluşu layihələrinin işlənməsi zamanı ərazinin mühəndiz təchizatının proqnoz və ya layihə materiallarından istifadə olunur. Bunun üçün hazırlıq zamanı meliorasiya, torpağın eroziyadan mühafizəsi, yolların yerləşməsi və.s tədbirlər planı və sxemi tədqiq edilir.Torpaq sahələri və obyektlərin yerləşmə yerlərini seçən komisiyaya yerquruluşu mühəndisi də daxildir. Ogər mühəndis təminatı layihələri mövcuddursa, ərazi təşkilinin bütün elementləri ona uyğun olaraq razılaşdırılır.

Bura mərkəzi fermaları (malikanələri) aşağıdakı obyektlərlə birləşdirən yollar daxildir.

- bölmə mərkəzləri;

- heyvandarlıq kompleksləri və fermalar;

- tarla düşərgəsi;

- tədarük, saxlama, emal məntəqələri; və s. obyektlər.

Təsərrüfatdaxili yolların yerləşməsi zamanı aşağıdakı məsələlər həll edilir:

- yolların istiqamətinin müəyyən edilməsi;

- səth örtüyünün kateqoriya və tipinin müəyyən edilməsi;

- trassa və onun üzərindəki süni qirğuların yerləşdirilməsi;

- görüləcək işlərin dəyərinin və ardıcıllığının müəyyən edilməsi.

Yol şəbəkəsi aşağıdakıları təmin etməlidir:

- $\quad$ rahat nəqliyyat əlaqələrini;

- nəqliyyat işlərinin maya dəyərinin azaldılması hesabına kənd təsərrüfatı istehsalının iqtisadi səmərəliliyinin artırılması;

- $\quad$ daşınma üçün vahid nəqliyyat sisteminin yaradılması;

- $\quad$ istehsalın ərazi təşkili və torpaq mühafizəsi üçün əlverişli şəraitin olmasi;

- minimal kapital qoyuluşu.

Yol şəbəkəsinin layihələşdirilməsi zamanı bü iş üçün mövcud olan bütün materiallardan istifadə edilir.İşlər aşağıdakı qaydada aparılır.

- mövcud yol şəbəkəsi və onun perspektiv inkişafını tədqiq edən hazırlıq işləri aparılır;

- nəqliyyat vasitələrinin sxemi tərtib olunur, daşınmanın həcmi və yolun istiqaməti müəyyən edilir;

- yolun kateqoriyası, örtüyün tipi və üzərindəki qurğunun növü müəyyən eilir;

- işlərin dəyəri aparılma ardıcıllığı müəyyən edilir.

Yolların yerləşdirilməsi zamanı ən mühim məsələ təsərrüfatdaxili yolların istiqamətinin müəyyən edilməsidir. Bu məqsədlə yük dövriyyəsi qrupu təyin edilir:

- rayon mərkəzləri, dəmir yolu stansiyaları, təsərrüfatlararası müəssisələrin mərkəzləri, komplekslər və emal müəssisələri;

- $\quad$ kənd təsərrüfat1 və sənaye müəssisələri, böyük yaşayış məntəqələri;

- bütün təsərrüfat mərkəzləri, ferma və digər istehsalat obyektləri;

- növbəli əkin sistemləri massivləri, çoxillik əkmələr və yem yerləri.

Avtonəqliiyatın gündəlik hərəkət intensivliyi aşağıdakı düstur görə müəyyən edilir:

$$
\mathbf{N}=(\mathbf{Q} \cdot \mathbf{K} \cdot \mathbf{a}):(\mathbf{T} \cdot \mathbf{n} \cdot \mathbf{q} \cdot \mathbf{P})
$$

N- yolun gündəlik hərəkət intensivliyi;

Q- illik yüklənmə gərginliyi; 
K- mövsimlik əmsalı, illik daşınmada qeyri-bərabərliyi nəzərə alır (kənd təsərrüfatı daşınmaları üçün 3-6-ya bərabərdir);

a- tranzit və sərnişin daşınmalarını nəzərə alan əmsal $(a=1,3-1,4)$;

T- yük daşınmalarının orta illik miqdarı (360-a bərabərdir);

n- hesabi avtomobilin yükgötürmədən istifadə əmsalı $(\mathrm{n}=0,8-0,9)$.

q- yolda olma əmsalı ( $\mathrm{q}=0,6-0,7)$;

P- hesabi avtomobilin orta hesabi yük götürməsi.

Bundan irəli gələrək, yol örtüyünün kateqoriyası, yol örtüyünün tipi və hərəkətin orta illik intensivliyi müəyyən edilir.

Yolların kateqoriyasının müəyyən edilməsi zamanı onun texniki-iqtisadi göstəriciləri müəyyən olunur.

- yol səthinin gediş-gəliş hissəsinin eni;

- $\quad$ səthin tipi.

1 və 2-ci qruplar üçün yolun eni 8-11 m, gediş-gəliş hissəsinin eni 4,5-7 m, 3-cü qrup üçün 6,5- $8 \mathrm{~m}$ və 3,5-4,5 m götürülür.

Yollar ilin istənilə vaxtında nəqliyyatı gediş -gəlişi üçün yararlı olmalıdır.

Zəruri hallarda yol obyektləri - körpülər, keçidlər də nəzərə alınır.

Yolların tikintisi üçün işçi planı hazırlanır və onun iqtisadi əsaslandırılması aparılır. Bunun üçün aşağıdakı düsturdan istifadə olunur:

$$
\partial=\left(P_{H} \cdot C\right): 100
$$

$\boldsymbol{\nabla}$ - yolların yaxşılaşdırılması nəticəsində əldə olunan qənaət;

$\mathbf{P}_{\mathbf{H}}$ - yolların yaxşılaşdırılması səbəbindən maya dəyərin aşağı salınması, \%;

C- istehsalın maya dəyəri.

Kapital qoyuluşunun öz xərcini çıxartma müddəti müəyyən edilir:

$$
\mathbf{T}=\mathbf{K}: \Delta \boldsymbol{\partial}
$$

T- Kapital qoyuluşunun öz xərcini çıxartma müddəti, il;

K- kapital qoyuluşunun həcmi;

$\Delta \boldsymbol{\partial}$ - yolların yaxşılaşdırılması nəticəsində əldə edilən illik qənaət.

Orazinin bütün mühəndis təminatı obyektlərini üç qrupa bölmək olar:

1. ərazi və ya sahə obyektləri (suvarma massivləri, su hövzələri, göllər və.s)

2. xətt obyektlər (magistral kanallar, kollektorlar, su ötürücülər, rabitə və elektrik ötürücüləri, yollar və.s)

3. hidrotexniki qurğular və eroziyaya qarşı obyektlər (bəndlər və s.).

Bütün bu obyektlərin yerləşməsi ərazinin təsərrüfatdaxili təşkilinə, torpaqlardan intensiv istifadəyə, torpaq nəmliyinin yaxşılaşmasına, ərazinin su təminatına, torpağın eroziya proseslərindən müdafiəsinə və həmçinin təbii landşaftın müdafiəsinə əsaslı təsir edir.

Meliorasiya obyektlərinin yerləşməsi zamanı çoxsaylı tələblər nəzərə alınır, məsələn, suvarma kanalları aşağıdakı tələblərə cavab verməlidir:

1. Düzgün suvarma qaydasına əməl etməklə torpağı normal su ilə təchiz etmək.

2. Torpaq, texnika və işçi qüvvəsində səmərəli istifadə etmək.

3. Otraf mühitin yaxşılaşdırması üçün şərait yaratmaq. 
4. Torpaqları suvarma eroziyasından, şorlaşma, şorakətləşmə və bataqlıqlaşmadan müdafiə təmin etmək.

5. Bina tikintisinə çəkilən illik xərcləri minimuma endirmək.

6. Suvarma massivləri sahə və konfiquriyasiyasına görə mövcud uqodiya və onların mühəndis təchizatı ilə bağlı olmalıdır.

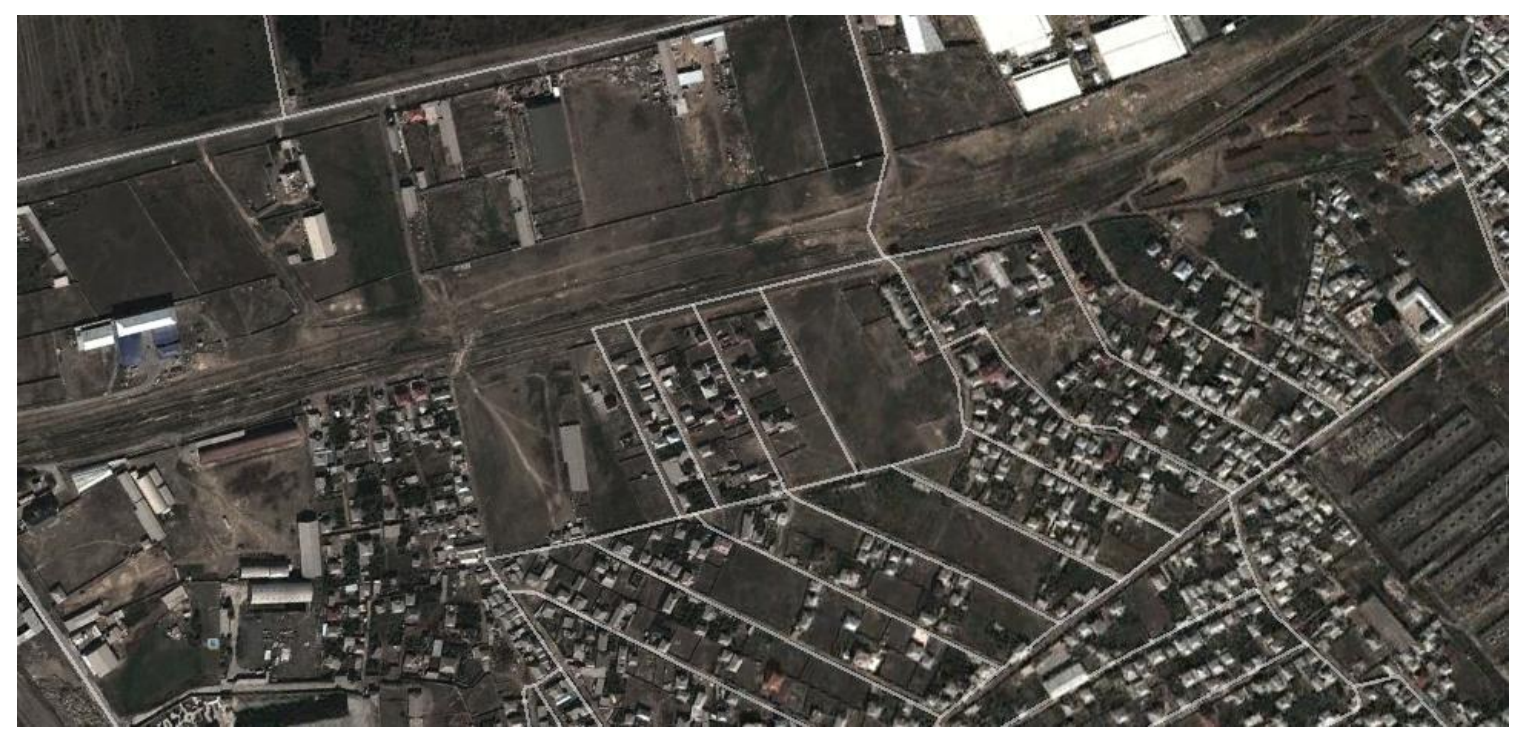

Gölməçə və su anbarlarının yerləşməsinə aşağıdakı tələblər qoyulur:

1. Su anbarlarının kifayət qədər dərinliyini təmin etmək.

2. Yaxın əraziləri su basmadan mühafizə etmək.

3. Su istifadəçilərinə yaxın yerləşdirmək.

4. Onların zəif sukeçiricilik qabliyyəti olan qrunt üzərində yerləşdirmək.

5. Daha çox su saxlamaq üçün şərait yatarmaq.

6. Bəndlərdən su sızmalarının qarşısını almaq.

Nəticə etibarı ilə meliorativ və su təsərrüfatı obyektlərinin yerləşməsinin iqtisadi əsaslandırılması aparılır. Bununla belə, təsərrüfatdaxili yerquruluşu layihələrində bu cür əsaslandırma iriləşdirilmiş göstəricilər əsasında verilir.

İllik məsariflər aşağıdakı düstur əsasında müəyyən olunur:

$$
C=C_{a}+C_{i}+C_{i x}+C_{n x}+C_{i g}+C_{t i b}
$$

$\mathbf{C}_{\mathbf{a}}-$ amortizasiya hesablamalar1;

$\mathbf{C}_{\mathbf{i}}$ - istismar xərcləri;

$\mathbf{C}_{\mathbf{i x}}$ - istehsalat xərcləri;

$\mathbf{C n}_{\mathbf{n x}}$ - əlavə məhsulun daşınmasına çəkilən xərclər;

$\mathbf{C}_{\mathbf{i g}}$ - itirilmiş gəlir gəlir;

$\mathbf{C}_{\text {tib }}$ - tarla işlərinin bahalaşması.

Layihə tədbirlərinin həyata keçirilməsi zamanı məhsul və ya gəlirin artımı (D) və xərclərə qənaət $\left(\mathbf{C}_{\mathbf{q}}\right)$ təmin edilir:

$$
D=d_{d}+C_{q}+d_{i}
$$


dd - əlavə məhsulun dəyəri;

$\mathbf{C}_{\mathbf{q}}$ - istehsalın illik xərclərinə qənaət;

di - istehsal itkilərinin qarşısının alınması.

$\mathrm{Bu}$ göstəricilərdən istifadə etməklə təmiz gəliri (dc ) və kapital qoyuluşunun xərcini çıxartma müddəti (T) müəyyən etmək olar:

$$
\begin{aligned}
\mathbf{d}_{\mathbf{c}} & =\mathbf{D}-\mathbf{C} \\
\mathbf{T} & =\mathbf{K}: \mathbf{d}_{\mathbf{q}}
\end{aligned}
$$

Təsərrüfatdaxili yerquruluşu zamanı mühəndis təchizatı obyektlərinin yerləşməsi sxem çərçivəsində, lakin texniki norma və qaydalara əsasən aparılır.

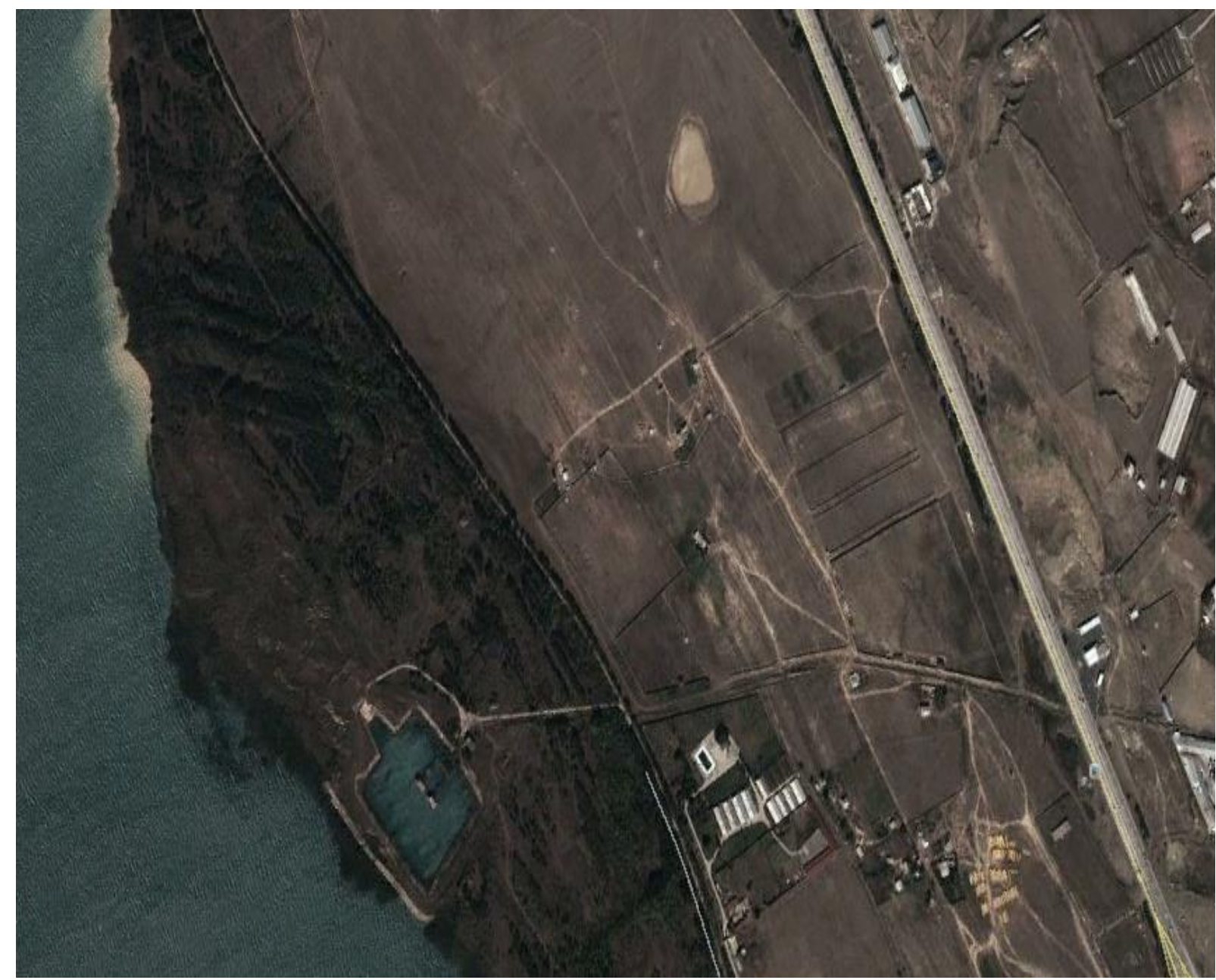

\section{ӘDӘВIYYAT}

1. «Torpaq islahatı haqqinda» Azərbaycan Respublikasının Qanunu, 2 avqust 1996-c1 il.

2. «Dovlət torpaq kadastrı, torpaqların monitorinqi və yerquruluşu haqqında» Azərbaycan Respublikasının Qanunu, 12 mart 1999-cu il.

3. «Torpaqların münbitliyi haqqında» Azərbaycan Respublikasının Qanunu, 30 dekabr 1999-cu il. 
4. «Azərbaycan Respublikasında torpaqların yeni normativ qiymətinin müəyyən edilməsi haqqında» Azərbaycan Respublikası Nazirlər Kabinetinin Qərarı, 23 iyul 1998-çi il.

5. Məmmədov Q.Ş. Azərbaycan torpaqlarının ekoloji qiymətləndirilməsi, Bakı, Elm, 1998. $-282 \mathrm{~s}$.

6. Məmmədov Q.Ş. Torpaq islahatı və Azərbaycanın aqroekoloji rayonlaşmasının müasir problemləri. M. 2000. s.127-128

7. M.Quliyev «Yerquruluşu» (dərs vəsaiti). Gəncə. 1992.

\title{
PLACED ON-FARM ROADS, WATER MANAGEMENT AND OTHER ENGINEERING STRUCTURES
}

\author{
${ }^{1}$ Aygul Mammadova, ${ }^{2}$ Dinara Aliyeva, ${ }^{3}$ Nurida Sadigov \\ 1,2,3 Department of Land Management, Land and Urban Cadastre, ${ }^{1,2,3}$ Azerbaijan State Agrarian \\ University. (Azerbaijan) \\ ${ }^{1,2}$ Head teacher, ${ }^{3}$ Assistant.
}

\begin{abstract}
The article provides information on how to locate on-farm roads, water facilities and other engineering facilities.

Requirements for these facilities include:

- The creation of favorable conditions for increasing the level of land use;

- Coherent arrangement between themselves and other parts of the land use project, ensuring proper territorial organization of production;

- Compliance with technical and environmental requirements during settlement;

- It has been noted that costs of construction and operation have been minimized.

It has been stated that during the on-farm construction engineering facilities are located within the scheme of operation according to technical regulations and rules

Keywords: On-farm roads, land plot, hydraulic structures, reclamation facilities, soil erosion, engineering facilities.
\end{abstract}




\title{
SIDERAT BITKILORIN VO MINERAL GÜBRӘLORIN PAMBIQ BITKISININ MəHSULDARLIĞINA VӘ IQTISADI SӘMӘRӘLILIYə TOSIRI
}

\author{
Ramilə Qəhrəmanova \\ Doktorant, assistent, Azərbaycan Dövlət Aqrar Universiteti \\ Email: qehremanova1977@mail.ru
}

Mövzunun aktuallığı. Aqrar sahədə inkişaf etmiş ölkələrdə aparılan tədqiqat işlərinin nəticələri göstərir ki, mineral gübrələrdən istifadənin səmərəni münbit torpaqlarda almaq olar. Belə ki, torpaqda mikrobioloji prosesləri fəallaşdıran, torpağın qida, istilik və su-fiziki xassələrini yaxşılaşdıran yüksək miqdarda üzvi maddələr, mikroelementlər, xeyirli mikroorqanizimlər, müxtəlif fermentlər olmalıdır. $\mathrm{Bu}$ isə torpağa müntəzəm olaraq bitki qalıqlarının və üzvi gübrələrin verilməsi ilə əldə oluna bilər. Torpaq münbitliyinin artırılmasında siderat bitkilərinyaşıl gübrələrin böyük əhəmiyyəti vardır. Dünya əkinçiliyində aparılan elmi-tədqiqat işləri göstərir ki, torpağın münbitliyini və pambığın məhsuldarlı̆̆ını yüksəltməyin ən etibarlı yolu yaşıl gübrələrin tətbiq olunmasıdır.

Odur ki, qloballaşan müasir dünyada kənd təsərrüfatında yeni bioloji əkinçilik sistemlərinin yaradılmasına böyük ehtiyac vardır. Uzun illər əkinçilik sistemində aparılmış elmi-tədqiqat işləri göstərir ki, kənd təsərrüfatı bitkilərinin becərilməsində, xüsusilə də pambığın becərilməsində mineral gübrələrdən, pestisidlərdən, herbisidlərdən, boy maddələrindən istifadə etmədən yüksək məhsul almaq və torpaq münbitliyini artırmaq mümkündür. Otraf mühitin və torpağın mühafizəsi baxımından kənd təsərrüfatında ekoloji təmiz məhsul əldə etmək üçün alternativ əkinçilik sistemlərinin və yeni becərmə aqrotexnologiyalarının işlənib hazırlanması aktual problemlərdən biridir.

İşin elmi yeniliyi. Tədqiqat işində ilk dəfə olaraq suvarılan boz-qəhvəyi (şabalıdı) torpaqlarda pambıq bitkisinin Gəncə-114 sortundan yüksək və keyfiyyətli xam pambıq məhsulu almaq üçün siderat bitkilərinin rolu öyrənilmişdir. Torpaga basdırılan siderat bitkilərin təsirindən torpağın aqrokimyəvi, su-fiziki xassələri yaxşılaşmış, məhsuldarlıq və məhsulun keyfiyyət göstəriciləri yüksəlmişdir.

Tədqiqatın yeri və metodikası. Suvarılan boz-qəhvəyi (şabalıdı) torpaqlarda tarla təcrübələri 2016-2019-cu illərdə Gəncə Regional Aqrar Elm və İnnovasiya Mərkəzində pambıq bitkisinin Gəncə-114 sortu ilə aparılmışdır.

Tarla təcrübələri aşağıdakı sxemdə qoyulmuşdur: 1) Nəzarət (hər il quza-payı sahədən çıxarılır); 2) $\mathrm{N}_{90} \mathrm{P}_{120} \mathrm{~K}_{90}$ (hər il quza-payı sahədən çıxarılır); 3) Hər il quza-payı payızda doğranıb əsas şum altına verilir; 4) Sonuncu vegetasiya suvarmasından əvvəl arpa səpilir və dekabr ayında bütün yerüstü kütlə, quza-payı ilə birlikdə doğranıb əsas şum altına verilir; 5) Sonuncu vegetasiya suvarmasından əvvəl payızlıq noxud səpilir və dekabr ayında bütün yerüstü kütlə, quza-payı ilə birlikdə doğranıb əsas şum altına verilir; 6) Sonuncu vegetasiya suvarmasından əvvəl payızlıq noxud arpa ilə bitlikdə qarışıq səpilir və dekabr ayında bütün yerüstü kütlə, quza-payı ilə birlikdə doğranıb əsas şum altına verilir.

Tarla təcrübələri pambıq bitkisinin Gəncə-114 sortu ilə 4 təkrarda qoyulmuşdur, hər variantın ümumi sahəsi $96,0 \mathrm{~m}^{2}(40 \times 2,4 \mathrm{~m})$ olmaqla, səpin cərgə üsulu ilə 60x15 (1 bitki) sm əkin sxemində, aprelin 2-ci ongünlüyündə (hektara $50 \mathrm{kq}$ toxum) aparılmışdır. Arpa $100 \mathrm{kq} / \mathrm{ha}$, noxud 
$60 \mathrm{kq} / \mathrm{ha}$ səpilmişdir. Mineral gübrələrdən azot-ammonium nitrat (34,7\%), fosfor-sadə superfosfat $(18,7 \%)$ və kalium-kalium sulfat (46\%) formasında, fosfor və kalium $80 \%$ payıda şum altına, qalan $20 \%$ yemləmədə, azot isə 2 dəfəyə yemləmə şəklində verilmişdir.

Professor N.Y.Seyidəliyevə görə pambıqçılıqda tətbiq edilən texnologiyaların tamamilə yenidən işlənməsi, yüksək məhsuldar, tez yetişən sortların tətbiqi, maddi-texniki bazanın möhkəmləndirilməsi, xəstəlik və zərərvericilərə qarşı səmərəli mübarizə tədbirlərinin hazırlanması və s. bu bitkinin məhsuldarlığını artırmaqla pambıqçılığı xalq təsərrüfatının ən rentabelli sahəsinə çevirmək mümkündür [4, s.4-9].

Mil-Qarabă̆ bölgəsində aparılan tədqiqatlarda bitki sıxlığı bir kolda olan qozaların sayına və bir qozadan çıxan xam pambığın kütləsinə təsir etmişdir. Öyrənilən bütün sortlarda $100 \mathrm{~min} / \mathrm{ha}$ bitki sıxlığında bir bitkidə olan qozaların sayı və bir qozadan çıxan xam pambığın çəkisi digər bitki sıxlığına nisbətən daha çox olmuşdur. Göstəricilər Gəncə-2, Gəncə-78 və Gəncə-110 sortlarında daha yüksək olmuşdur [5, s.4-11].

S.Z.Məmmədovanın və E.H.Aslanovanın apardıqları tədqiqatda müəyyən edilmişdir ki, peyinlə birlikdə mineral gübrələrin pambıq bitkisi altında tətbiqi məhsuldarlıqla yanaşı olaraq xam pambıq lifinin texnoloji keyfiyyətlərinə də əhəmiyyətli dərəcədə təsir göstərir. Gübrələrin birlikdə təsirindən pambıq lifinin qirılma yükü 0,5-0,6 qq, xətti sıxlıq 560-600 m.teks, nisbi q1rılma uzunluğu 5,8-6,0 qq/teks və ştapel uzunluğu 4/5 mm nəzarət (gübrəsiz) variantına nisbətən artır. Xam pambıq lifinin texnoloji keyfiyyətlərinin ən yüksək göstəriciləri peyin $10 \mathrm{t} / \mathrm{ha}+\mathrm{N}_{120} \mathrm{P}_{150} \mathrm{~K}_{120}$ variantında müşahidə edilmişdir [68, s.68-70].

H.Ә.Aslanovun və A.C.İbrahimovun apardıqları tədqiqatlar göstərir ki, fasiləsiz pambıq əkinlərində üzvi və mineral gübrələr məhsuldarlıqla yanaşı torpağın münbitliyinin artmasına da müsbət təsir göstərmişdir. Belə ki, nəzarət (gübrəsiz) variantında torpağın əkin qatında (0-30 sm) mütəhərrik fosforun miqdarı 15,0 mq/kq, mübadiləvi kalium 204,0 mq/kq olduğu halda, gübrələrin təsirindən bütün variantlarda qida maddələrinin miqdarının artması müşahidə olunmuşdur. On yaxş1 nəticələr hektara hər il 9 ton peyin $+\mathrm{N}_{90} \mathrm{P}_{90} \mathrm{~K}_{45}$ variantında alınmış, mütəhərrik fosforun miqdarı 27,8 mq/kq-a, mübadiləvi kalium isə 300,0 mq/kq-a qədər artmışdır [1, c-6, s. 38-39]. Keçmiş Pambıqşılıq ET İnstitutunda monokultura şəraitində üzvi və mineral gübrələrin daimi tətbiqinin pambıq bitkisinin fenoloji göstəricilərinə və məhsuldarlı̆̆ına təsiri öyrənilmişdir. Müəyyən edilmişdir ki, üzvi və mineral gübrələrin sistematik olaraq uzun müddət birlikdə verilməsi bitnin böyüməsinə, bar orqanlarının miqdarına, onların kütləsinə müsbət təsir etməklə xeyli miqdarda məhsul artımına səbəb olmuşdur. Üzvi və mineral gübrələr torpağa verildikdə, onlar öz müsbət təsirini sonrakı illərdədə saxlayırlar. Gübrələrin sistematik olaraq uzun müddətli verilməsi peyin $9 \mathrm{t} / \mathrm{ha}+\mathrm{N}_{90} \mathrm{P}_{90} \mathrm{~K}_{45}$ variantında daha səmərəli olmuşdur [3, s. 51-53].

Özbəkistan Respublikasında apardılan tədqiqatlarda ən yüksək xam-pambıq məhsulu şırımın uzunluğu $200 \mathrm{~m}$ və şırıma verilən su sərfi 0,3 1/san olduqda alınmışdır. Eyni zamanda 1000 toxumin kütləsi 114-120 qr, lif çıxımı 35,2-34,6\%, lifin uzunluğu 28,3-32,0 mm, qırılma yükü 4,9-5,0 qq və xətti sıxlıq 189-190 m/teks təşkil etmişdir [7, s. 55-57].

A.V.Kartaşov və A.N.Abaldovun Stavropol vilayətində orta lifli pambıq sortları ilə apardıqları tədqiqatlarda gübrəsiz variantda xam pambıq məhsulu 1,15-1,18 t/ha olduğu halda, mineral gübrələrin $\mathrm{N}_{90} \mathrm{P}_{45} \mathrm{~K}_{90}$ norması öyrənilən sortlar üzrə məhsuldarlığ1 0,08-0,35 t/ha yüksəltmişdir. Eyni zamanda mineral gübrələr pambığın təsərrüfat göstəricilərini mahlıc çıxımını, bir qozadakı xam-pambığın kütləsini və mahlıcın uzunluğunu artırmışdır. Pambıq bitkisi altında mineral gübrə normaların optimallaşdırılması bitkinin ümumi suya olan təlabatına azalmasına təsir göstərir [8, s. 68-72; 9, s. 91-93].

Pambığın məhsuldarlığı 3 ildən orta hesabla nəzarət (gübrəsiz) variantında $27,1 \mathrm{~s} /$ ha olduğu halda, ən yüksək xam pambıq məhsulu peyin $10 \mathrm{t} / \mathrm{ha}+\mathrm{N}_{120} \mathrm{P}_{150} \mathrm{~K}_{120}$ variantında $44,9 \mathrm{~s} / \mathrm{ha}$ 
müşahidə edilmiş, artım nəzarətə nisbətən $17,8 \mathrm{~s} /$ ha və ya $65,7 \%$ olmuş, hər bir kiloqram NPKya düşən xam pambıq məhsulu 3,90 kq təşkil etmişdir [2, s.20].

Özbəkistan respublikasında M.Tadjiyev, K.M.Tadjiyev və B.A.Xalmanov tərəfindən aparılan tədqiqatlarda qısa rotasiyalı növbəli əkin sistemində pambığın Buxara-102 sortundan nəzarətdə $30 \mathrm{~s} /$ ha xam pambıq məhsulu, payızlıq buğda və yem noxudu sələfindən sonra pambıq əkilmiş sahədən $35,6 \mathrm{~s} /$ ha xam pambıq məhsulu alınmış, bir qozadakı xam pambığın kütləsi uyğun olaraq 5,5 qr və 6,2-6,4 qr olmuşdur [10, s. 8-9].

Mil düzü şəraitində apardıqları tədqiqatlarda müəyyən edilmişdir ki, aqrotexniki tədbirlər pambıq bitkisinin struktur göstəricilərinə, bir qozadan çıxan xam-pambığın kütləsinə, lif çıxımına, lifin texnoloji göstəricilərinə əhəmiyyətli dərəcədə təsir göstərir [11, s. 53-55; 6, s.9399].

İ.A.Buriyev tərəfindən Özbəkistanın Qaşqadərya vilayətində aparılan tədqiqatlarda pambıq bitkisinin optimal boyu, inkişafı və məhsuldarlığı 10-15 martda səpin apardıqda, 60x16 (1) sm əkin sxemində, bir hektarda 90 min bitki sıxlığında və mineral gübrələrin $\mathrm{N}_{200} \mathrm{P}_{140} \mathrm{~K}_{100}$ normasında öyrənilən Namanqan-77 sortundan 32,5 s/ha, Buxara-6-dan 34,5 s/ha, C-6530-dan 30,1 s/ha, Mehrdən 35,2 s/ha alınmışdır [12, s.20-21].

Tacikistan respublikasında aparılan tədqiqatlarda azotlu gübrələrin $(75-150 \mathrm{kq} / \mathrm{ha})$ yüksək olmayan normaları peyin 15 və 30 t/ha zəminində fosfor və kalium gübrələrinin $\mathrm{P}_{200} \mathrm{~K}_{100}$ normasında pambıqdan 32,5-34,0 s/ha məhsul alınmışdır [13, s. 51-58].

Bizim tərəfimizdən aparılan tədqiqatın nəticələri göstərir ki, siderat bitkilər və mineral gübrələr pambıq bitkisinin məhsuldarlığına əhəmiyyətli dərəcədə təsir göstərir. Tədqiqatın nəticələrinə əsasən pambıq bitkisinin məhsuldarlığı 3 ildən orta hesabla nəzarət (hər il quza-payı sahədən çıxarılır) variantında xam-pambıq məhsulu 24,7 s/ha olmuşdur. Mineral gübrələrin və doğranıb şumlanmış bitkilərin təsirindən xam-pambıq məhsulu əhəmiyyətli dərəcədə yüksəlmişdir. Belə ki, $\mathrm{N}_{90} \mathrm{P}_{120} \mathrm{~K}_{90}$ (hər il quza-payı sahədən çıxarılır) variantında $41,1 \mathrm{~s} /$ ha, artım nəzarətə nisbətən $16,4 \mathrm{~s} /$ ha və ya $66,0 \%$, hər il quza-payı doğranıb şumlanmış varintda $28,2 \mathrm{~s} / \mathrm{ha}$, artım nəzarətə nisbətən $3,5 \mathrm{~s} /$ ha və ya $14,0 \%$ təşkil etmişdir. Sonuncu vegetasiya suvarmasından əvvəl cərgəarasına səpilmiş arpa yerüstü kütlə ilə birlikdə dekabrda doğranıb şumlanmış variantda 32,3 $\mathrm{s} / \mathrm{ha}$, artım nəzarətə nisbətən $7,6 \mathrm{~s} /$ ha və ya $31,0 \%$, sonuncu vegetasiya suvarmasindan əvvəl cərgəarasına səpilmiş payızlıq noxud yerüstü kütlə ilə birlikdə dekabrda doğranıb şumlanmış variantda $35,3 \mathrm{~s} / \mathrm{ha}$, artım nəzarətə nisbətən $10,6 \mathrm{~s} /$ ha və ya $43,0 \%$ təşkil etmişdir. Sonuncu vegetasiya suvarmasından əvvəl cərgəarasına arpa ilə birlikdə səpilmiş payızlıq noxud yerüstü kütlə ilə birlikdə dekabrda doğranıb şumlanmış variantda 39,4 s/ha, artım nəzarətə nisbətən 14,7 s/ha və ya $60,0 \%$ olmuşdur.

Siderat bitkilərin və mineral gübrələrin pambıq bitkisi altında tətbiqinin səmərəliliyinin riyazi hesablanması təcrübənin dəqiqliyini sübut edir. Belə ki, variantlar üzrə $\operatorname{artım~} \mathrm{E}, \mathrm{s} / \mathrm{ha}$ göstəricisindən üç dəfədən çox yüksək olmaqla $\mathrm{E}=0,87-1,0 \mathrm{~s} / \mathrm{ha}$, təcrübənin dəqiqliyi isə $\mathrm{P}=2,56-2,94 \%$ təşkil etmişdir.

İqtisadi səmərəlilik. Siderat bitkilərin və mineral gübrələrin pambıq bitkisi altında iqtisadi səmərəliliyə təsiridə öyrənilmişdir. Siderat bitkilər və gübrələr torpağın aqrokimyəvi, su-fiziki xassələrini, məhsuldarlığı və onun keyfiyyət göstəricilərini yüksəltməklə yanaşı, əlavə məhsula çəkilən xərcləri də artırmışdır. İqtisadi səmərəlilik hesablanarkən siderat bitkilərin və mineral gübrələrin tətbiqinə və əlavə məhsul istehsalına çəkilən bütün xərclər nəzərə alınmışdır. Təcrübələrin nəticələrini hesablamaq üçün 2019-cu ildəki qiymətlərdən istifadə edilmişdir. 
Mineral gübrələrdən və aqrotexniki tədbirlərdən asılı olaraq bir hektar pambıq sahəsindən alınmış xalis gəlir 1186,8 manat, rentabellik səviyyəsi 80,0\% olmuşdur. Birlikdə səpilmiş arpanın, noxudun və pambığın yerüstü hissəsəini doğrayıb şum altına verdikdə daha yüksəo xalis gəlir $1180,0 \mathrm{man} / \mathrm{ha}$ alınmış, rentabellik səviyyəsi isə $85,5 \%$ təşkil etmişdir.

Nəticə. Pambığın məhsuldarlığı nəzarət (hər il quza-payı sahədən çıxarılır) variantında 3 ildən orta hesabla 24,7 s/ha olduğu halda, ən yüksək məhsuldarlıq 2-ci $\left(\mathrm{N}_{90} \mathrm{P}_{120} \mathrm{~K}_{90}\right.$ (hər il quza-pay1 sahədən çıxarılır)) variantda $41,1 \mathrm{~s} / \mathrm{ha}$, artım nəzarətə nisbətən $16,4 \mathrm{~s} /$ ha və ya $66,0 \%$; siderat bitkiləri variantları arasında isə onların qarışıq əkilən variantında: 6-cı (sonuncu vegetasiya suvarmasından əvvəl cərgəarasına arpa ilə birlikdə səpilmiş payızlıq noxud yerüstü kütlə ilə birlikdə dekabrda doğranıb şumlanmış) variantda uyğun olaraq 39,4 s/ha, artım 14,7 s/ha və ya $60,0 \%$ təşkil etmişdir. Lakin ən yüksək məhsuldarlıq 2-ci variantda olmasına baxmayaraq, rentabellik səviyyəsi burada $80,0 \%$, 6-c1 varianta isə 85,5\% təşkil etmişdir. Beləliklə, fasiləsiz pambıq əkinlərində mineral gübrə tətbiq etmədən, siderat bitkilərin hesabına da pambıqdan yüksək məhsul almaq mümkündür.

Açar sözlər: pambıq, sideratlar (payızlıq noxud, arpa), münbitlik, məhsuldarlıq, iqtisadi səmərəlilik, rentabellik.

\section{ӘDӘBIYYAT}

1. 1.Aslanov H.Ә., İbrahimov A.C. Fasiləsiz pambıq əkinlərində üzvi və mineral gübrələrin torpağın münbitliyinə və məhsuldarlığına təsiri // Azərbaycan Aqrar Elmi, 2010, №6, s.38-39

2. Aslanova E.H. Mil düzü pambıqaltı torpaqlarında üzvi və mineral gübrələrin effektliyinin ekoloji əsasları: Aqrar elm. üzrə fəlsəfə doktoru diss. ... avtoref. Bakı, 2018, 20 s.

3. İbrahimov A.C., Mehdiyeva G.R. Monokultura şəraitində üzvi və mineral gübrələrin daimi tətbiqinin pambıq bitkisinin fenoloji göstəricilərinə və məhsuldarlığına təsiri // Azərbaycan ET Pambıqçılıq İnstitutunun Osərlər məcmuəsi.-Gəncə, 2014, №79, s.51-53

4. Seyidəliyev N.Y. Azərbaycanda pambıqçılığın inkişaf dinamikası və möcud problemlər // ADAU-nun Elmi Osərləri. Gəncə: ADAU nəşriyyat1, 2013, №1, s.4-9

5. Seyidəliyev N.Y. Bitki sıxlığının pambıq bitkisinin struktur göstəricilərinə təsiri //ADAU-nun Elmi Osərləri. Gəncə: ADAU nəşriyyat1, 2012, №1, s.4-11

6. Seyidəliyev N.Y., Xəlilov X.Q., Məmmədova M.Z. Aqrotexniki tədbirlərin pambıq sortlarının struktur göstəricilərinə təsiri. Azərbaycan Milli Elmlər Akademiyası Gəncə bölməsi. Xəbərlər Məcmuəsi № 1(67), Gəncə-2017, s. 93-99

7. 7.Исаев С.Х., Таджиев С.С. Режимы почв и урожайность хлопчатника в зависимости от длины поливной борозды // М.: Аграная наука, 2018, №4, с.55-57

8. Карташов А.В. Фотосинтетическая продуктивность сортов средневолокнистого хлопчатника на богаре Научное обеспечение развития растениеводства // Теоретический и научно-практический журнал Вестник Орел ГАУ ФГОУ ВПО Орел ГАУ, 2010, с. 68-72

9. Абалдов А.Н., Карташов А.В. Экономические перспективы неорошаемого хлопководства на юге России // Аграрный вестник Урала, 2010, № 9-10, С. 91-93

10. 10.Таджиев М., Таджиев К.М., Халманов Б.А. Влияние короткоротационного севооборта на урожайность хлопчатника // М.: Аграрная наука, 2016 №1, с. 8-9 
11. Мамедова М.З. Определение агротехнических приёмов повышающих урожайности хлопка-сырца и технологических показателей волокна. ADAU-nun elmi əsərləri. Gəncə-2011, №3 s.53-55

12. Буриев И.А. Урожайность сортов хлопчатника в зависимости от сроков сева, схемы размещения и густоты стояния // М.: Аграрная наука, 2014, №10, с.20-21

13. Холов Б.Н., Султанов М.С., Ибрагимов Н.Ш. Некоторые итоги агрохимических исследований в Таджикистане // М.: Проблемы агрохимии и экологии, 2011, №1, c. $51-58$

\title{
EFFECT OF SIDERATE CROPS AND MINERAL FERTILIZERS ON COTTON CROP PRODUCTIVITY AND ECONOMIC EFFICIENCY
}

\author{
Ramila Gahramanova \\ Doctoral degree student, assistant, Azerbaijan State Agrarian University. \\ Email: qehremanova1977@mail.ru
}

Objective: The actuality of the subject. The results of research conducted in developed countries in the field of agriculture show that the benefits of the use of mineral fertilizers can be obtained on fertile soils. Thus, the soil must contain a large amount of organic matter, trace elements, beneficial microorganisms, various enzymes that activate microbiological processes, improve the nutritional, thermal and hydro-physical properties of the soil. This can be achieved by regular application of plant residues and organic fertilizers to the soil. Siderate plants - green fertilizers - play an important role in increasing soil fertility. Research in world agriculture shows that the most reliable way to increase soil fertility and cotton productivity is to apply green manure.

The scientific novelty of the work. For the first time in the research work, the role of siderate plants to get high and quality raw cotton product from Ganja-114 variety of cotton plant on irrigated gray-brown (chestnut) soils was studied. Due to the influence of siderate plants buried in the soil, the agrochemical, hydro-physical properties of the soil have improved, productivity and product quality have increased.

Methods: Place and methodology of research. Field experiments on irrigated gray-brown (chestnut) soils were conducted in 2016-2019 at the Ganja Regional Agrarian Science and Innovation Center with Ganja-114 variety of cotton plant.

Field experiments are set out in the following scheme: 1) Control (each year the lambs are removed from the field); 2) N90P120K90 (lambs are removed from the field every year); 3) Every year the lambs are cut in autumn and given to the main plow; 4) Before the last irrigation of the vegetation, barley is sown and in December the whole surface mass, together with the lambs, is chopped and given to the main plow; 5) Before the last vegetation irrigation, autumn peas are sown and in December the whole surface mass is cut together with the lambs and given to the main plow; 6) Before the last vegetation irrigation, autumn peas are sown in a mixture of barley and lice, and in December the whole surface mass is cut together with the lamb and put under the main plow. 
Results: Economic efficiency. The effect of siderate crops and mineral fertilizers on economic efficiency under cotton has been studied. Siderate plants and fertilizers not only improved the agrochemical, hydro-physical properties, productivity and quality of the soil, but also increased the cost of additional products. All costs incurred in the application of siderate plants and mineral fertilizers and in the production of by-products were taken into account in the calculation of economic efficiency. Estimates for 2019 were used to calculate the results of the experiments. The price of one ton of mineral fertilizers in physical weight is 430 manats of ammonium salt, 129 manats with $70 \%$ discount, 520 manats with simple superphosphate, 156 manats with $70 \%$ discount, 649 manats of potassium sulfate. 194.7 manat with $70 \%$ discount. The cost of mineral fertilizers to be applied per hectare is 12 manat, barley seeds $60 \times 0.5=30$ man / ha, pea seeds $60 x 0.7=42 \mathrm{man} /$ ha, sowing $35.0 \mathrm{man} / \mathrm{ha}$, surface area cutting was taken to $30 \mathrm{man} / \mathrm{ha}$, plowing to $35.0 \mathrm{man} / \mathrm{ha}$.

Net income is determined based on all costs incurred in the additional product and at the market selling price of that product. The market price of one kilogram of raw cotton was raised to 0.65 manat.

Conclusion: In the control option of cotton yield (lambs are removed from the field every year) with an average of $24.7 \mathrm{~s} /$ ha for 3 years, the highest productivity is in the 2nd (N90P120K90 (lambs per year). $41.1 \mathrm{~s} /$ ha in the variant, $16.4 \mathrm{~s} /$ ha or $66.0 \%$ in relation to the growth control, and the 6th (last row before the last vegetation irrigation, sown with barley in the autumn) peas were chopped and plowed in December together with the surface mass) was $39.4 \mathrm{~s} / \mathrm{ha}, 14.7 \mathrm{~s} /$ ha or $60.0 \%$, respectively. However, despite the highest productivity in the 2nd option, the highest net income was 1186.8 manat, the profitability level was $80.0 \%$ and was lower than in the 6th option - the highest net income was 1200, 0 man / ha, and the level of profitability was $88.2 \%$.

Keywords: cotton, siderates (autumn peas, barley), fertility, productivity, economic efficiency, profitability. 


\title{
НЕКОТОРЫЕ РЕЗУЛЬТАТЫ УЧЕНЫХ МГУ И РАН ПО ВОПРОСАМ НАКОПЛЕНИЯ ХИМИЧЕСКИХ ЭЛЕМЕНТОВ В ОРГАНИЗМАХ
}

\author{
${ }^{1}$ Сергей Остроумов, ${ }^{2}$ Сергей Котелевцев, ${ }^{3}$ Евгений Криксунов \\ ${ }^{1}$ Доктор биол.наук, ведущий научный сотрудник лаборатории физхимии биомембран биологического \\ факультета МГУ; \\ ${ }^{2}$ Доктор биол.наук, ведущий научный сотрудник лаборатории физхимии биомембран биологического \\ факультета МГУ; \\ ${ }^{3}$ Член-корреспондент РАН, профессор кафедры ихтиологии биологического факультета МГУ)
}

\section{РЕЗЮМЕ}

В данной статье суммированы некоторые результаты исследований ученых МГУ и Российской академии наук, которые изучали накопление химических элементов организмами (на примере некоторых биологических видов). Обобщение результатов проводится в связи с представлениями В.И. Вернадского о биосфере. Учитываются современные проблемы загрязнения окружающей среды. Среди тех химических элементов, данные о которых получены в рассмотренных в статье работах - тяжелые металлы и некоторые другие элементы.

Ключевые слова: биосфера, химическая экология, биогеохимия, геохимия, химические элементы, миграция элементов в биосфере, накопление, биоаккумуляция, металлы, биомасса, растения, животные

\begin{abstract}
In this article, a summation is made of some of research results of scientists of Moscow State University and Russian Academy of Sciences on accumulation of chemical elements by organisms (exemplified by some biological species). The summation of the results is made in connection with concepts of V.I.Vernadsky on the biosphere. The contemporary issues of environmental pollution are taken into consideration. The chemical elements that are considered include heavy metals and some other elements.
\end{abstract}

Keywords: biosphere, chemical ecology, biogeochemistry, geochemistry, chemical elements, migration of elements in the biosphere, accumulation, bioaccumulation, metals, biomass, plants, animals

Введение: В 2009 году один из соавторов (С.А.О.) был приглашен прочитать лекцию на Всероссийской конференции «Экотоксикология-2009» (на базе Института биохимии и физиологии микроорганизмов им. Г.К. Скрябина РАН), которая затрагивала в том числе проблемы биогеохимии и измерения содержания отдельных химических элементов в биогенном материале. Затем последовали его доклады на Биогеохимических чтениях памяти В.В. Ковальского в Институте геохимии и аналитической химии им. В.И. Вернадского РАН, на Ломоносовских чтениях в МГУ им. М.В. Ломоносова, заседаниях МОИП (Московское общество испытателей природы) и доклады на других форумах. Поэтому возникла на целесообразность подготовки обобщающих материалов.

Цель этой работы: внести вклад в суммирование и систематизацию некоторых публикаций ученых Московского государственного университета имени 
М.В. Ломоносова (МГУ) и РАН, имеющие отношение к упомянутым докладам и лекциям. Данная работа не выходит за рамки этой конкретной и ограниченной задачи и не является ни обзором литературы, ни текстом лекции.

В работе многих поколений ученых творческим стимулом служили и служат труды Владимира Ивановича Вернадского (1863-1945).

В.И. Вернадский заложил основы учения о биосфере в своих публикациях, в том числе в книге «Биосфера», со дня выхода которой из печати прошло уже больше 80 лет. Это учение успешно развивается и обогащается новыми фактами. Концептуальное развитие этого учения происходит значительно медленнее. Теоретические разработки базируются на работе по сбору и анализу новых фактов. Ряд соответствующих публикаций отражен в данной работе (см. Таблицы 1-4).

В работе использованы следующие сокращения: ДАН - Доклады академии наук (научный журнал РАН); ДНОК - динитроортокрезол (пестицид); ДСН - додецилсульфат натрия; ЕС50 - эффективная концентрация, вызывающая эффект величиной 50\%; ЖМС жидкое моющее средство; КПАВ - катионное (катионогенное) поверхностно-активного вещество; ПАВ - поверхностно-активное вещество; СПАВ - синтетическое поверхностно-активное вещество; СГМА - сополимер гексена и малеинового альдегида; СМC - синтетическое моющее средство; SDS - додецилсульфат натрия; ТДТМА тетрадецилтриметиламмоний бромид (катионогенный ПАВ); ТX - Тритон X100 (неионогенный ПАВ); ЦТАБ - цетилтриметиламмоний бромид;

Некоторые результаты работы по сбору и анализу новых фактов: Анализируя сущность науки, В.И. Вернадский писал: «Научный аппарат из миллиарда миллиардов все растущих фактов, постепенно и непрерывно охватываемых эмпирическими обобщениями, научными теориями и гипотезами, есть основа и главная сила, главное орудие роста современной научной мысли».

Необходимы исследования и накопления веществ в организмах, изучение воздействия веществ на организмы, и анализ обратного воздействия организмов на химизм среды - a именно, воздействия организмов на концентрации веществ в среде.

Наша работа включала в себя исследования в нескольких направлениях, в том числе изучение накопления, концентраций загрязняющих веществ в организмах образцах биогенных материалов.

Отметим также, что исследования в этом и других смежных направлениях - важнейшая часть современной научной базы практической работы по сохранению окружающей среды. Это нашло свое отражение в анализе, проведенном в наших книгах [56-57, 68-69]. В самое последнее время нарастает понимание роли организмов в очищении среды обитания, что делает перспективным изучение их в связи с поиском экотехнологий (в том числе фитотехнологий) для снижения химического загрязнения среды, в том числе водной [33-40, 43-45, 64, 65]. Ниже суммированы некоторые работы автора по накоплению новых фактов. При рассмотрении этих фактов полезно помнить слова М.В. Ломоносова «Один опыт я ставлю выше, чем тысячу мнений, рожденных только воображением».

В.И. Вернадский писал: «Жизнь - живое вещество - поистине является одной из самых могущественных геохимических сил нашей планеты, а вызываемая ею биогенная миграция атомов представляет форму организованности первостепенного значения в строении биосферы» (Вернадский, 1965, стр.297). Поэтому необходимы исследования 
накопление химических элементов в организмах. Эта работа, необходимая сама по себе, представляет интерес и в связи с исследованием биогеохимических потоков в биосфере.

Определенная часть работ ученых МГУ проводилась в содружестве с учеными Российской академии наук (Институт геохимии и аналитической химии, Институт океанологии, Институт биохимии), АН Молдовы и Университета штата Массачусетс (г. Амхерст, США).

Ниже приведены примеры этих исследований. Необходимо еще раз подчеркнуть, что данная публикация не является обзором. Помимо упоминаемых здесь работ есть большое количество ценных исследований и других ученых МГУ, проводимых на многих факультетах, в том числе факультете почвоведения, географическом факультете, геологическом факультете и других факультетах, а также во многих лабораториях и институтах Российской академии наук (РАН).

Примеры работ по определению концентрации химических элементов в организмах: Часть полученных автором результатов по вопросам измерения концентраций химических элементов, накопление веществ в организмах, образцах биомассы и биогенных материалов отражена в нижеследующей таблице 1.

Таблица 1 Примеры работ с участием ученых МГУ по изучению накопление элементов в организмах и их роль в биогеохимических потоках элементов (измерения концентраций химических элементов, накопление веществ в организмах, образцах биомассы и биогенных материалов). Если имя автора для краткости не указано, то автором является C.A.O.

\begin{tabular}{|c|c|}
\hline О результатах работы & Ссылки \\
\hline $\begin{array}{l}\text { Получены новые данные о концентрации и } \\
\text { накоплении нескольких металлов в биомассе } \\
\text { элодеи канадской из пресноводного водоема в } \\
\text { Московской области, проведено сравнение этих } \\
\text { данных с концентрациями металлов в элодее } \\
\text { канадской в другой стране. }\end{array}$ & $\begin{array}{l}\text { Остроумов, С. А., Данилова, В. Н., Хушвахтова, } \\
\text { С. Д., Ермаков, В. В., Тютиков, С. Ф., Тропин, И. } \\
\text { В., \& Котелевцев, С. В. (2016). Содержание } \\
\text { химических элементов, глутатиона и } \\
\text { металлотионеинов в элодее канадской (Elodea } \\
\text { canadensis) в связи с экологическим } \\
\text { мониторингом. Экологическая химия, 25(4), 197- } \\
203 .\end{array}$ \\
\hline 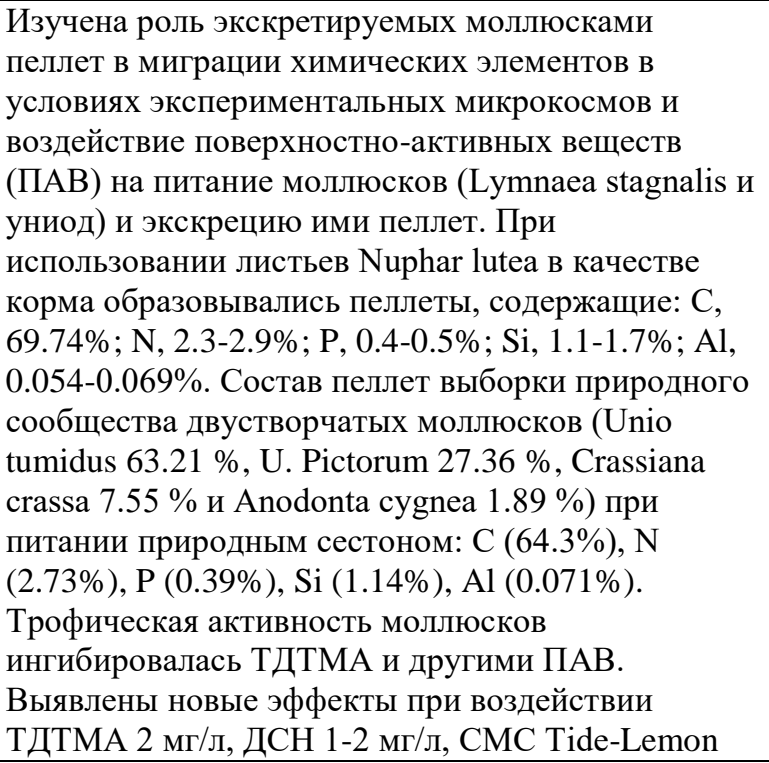 & $\begin{array}{l}\text { Пеллеты моллюсков в биогеохимических потоках } \\
\text { С, N, P, Si, Al // ДАН. 2001. Т. 379. № 3. С. 426- } \\
\text { 429. Библиогр. } 12 \text { назв. [Совместно: С.А.О., } \\
\text { Колесников М.П.]. }\end{array}$ \\
\hline
\end{tabular}


75 мг/л: ингибировали трофическую активность Lymnea stagnalis. Новые результаты

свидетельствовали об ингибировании переноса вещества через данное звено трофической цепи и возможности антропогенного нарушения биогеохимических потоков.

Elemental composition $(\mathrm{C}, \mathrm{N}, \mathrm{P}, \mathrm{Si}, \mathrm{Al})$ of pellets formed by mollusks Lymnaea stagnalis feeding on the leaves of Nuphar lutea and Taraxacum officinale; amount (wet weight, dry weight) of pellets formed by L. stagnalis feeding on the leaves of $\mathrm{N}$. lutea and $\mathrm{T}$. officinale; transfer of matter and chemical elements (C, N, P, Si, Al) with pellets of freshwater bivalves (unionids Unio sp., etc.) per unit biomass of mollusks and per unit area of the ecosystem of the river; transfer of matte and chemical elements $(\mathrm{C}, \mathrm{N}, \mathrm{P}, \mathrm{Si}$, $\mathrm{Al}$ ) with pellets of L. stagnalis per unit biomass of mollusks and per unit area of the ecosystem of the pond. Synthetic surfactants TDTMA $2 \mathrm{mg} / \mathrm{l}$, SDS 1-2 $\mathrm{mg} / \mathrm{l}$, detergent Tide-Lemon $75 \mathrm{mg} / \mathrm{l}$ inhibited the trophic activity of L. stagnalis. Percents of food assimilability of taxons of invertebrates, from Rotatoria (48-80) to Diptera (1-3)]. DOI 10.1023/A:1011620817764.

Нов. факты о составе пеллет, о переносе химич. элементов в биогеохим. потоках.

Изучали роль экскретируемых моллюсками пеллет в миграции химических элементов в условиях экспериментальных микрокосмов и воздействие катионного поверхностно-активного вещества (КПАВ, ПАВ) на питание моллюсков (Lymnea stagnalis и унионид) и экскрецию ими пеллет фекалий и псевдофекалий. Показано, что моллюски L. stagnalis экскретируют пеллеты со скорость 4-7 мг (сухого веса) на 1 г сырого веса моллюсков за 72 часа. При использовании листьев Nuphar lutea в качестве корма образовывались пеллеты, содержащие: C, 69,74\%; N, 2,3-2,9\%; Р, 0,4-0,5\%; Si, 1,1-1,7\%; Al, 0,054-0,059\%. B присутствии 2 мг/л КПАВ тетрадецилтриметиламмоний бромида (ТДТМА) скорость питания L. Stagnalis снижалась на 27,970,9\%. При этом образование пеллет на 1 г сырого веca L. Stagnalis снижалось на 41,7\% (за период инкубации 72 часа). Состав пеллет выборки природного сообщества двустворчатых моллюсков (Unio tumidus 63,21\%, U. pictorum $27,36 \%$, Crassiana crassa 7,55 \% и Anodonta cygnea 1,89 \%) при питании природным сестоном: C $(64,3 \%), \mathrm{N}(2,73 \%), \mathrm{P}(0,39 \%), \mathrm{Si}(1.14 \%), \mathrm{Al}$ $(0,071 \%)$. Фильтрация ими воды также ингибировалась ТДТМА и другими ПАВ. Это свидетельствовало об ингибировании переноса вещества через данное звено трофической цепи и
Pellets of some mollusks in the biogeochemical flows of C, N, P, Si, and Al. - Doklady Biological Sciences, 2001. Vol. 379, P. 378-381. Bibliogr. 12. (Translated from: DAN 2001. Vol. 379. No. 3. P. 426-429). ISSN 0012-4966. [In collaboration: S.A.O., Kolesnikov M.P.]
Biogeochemical role of bivalves: transfer of chemical elements with pellets // Ecol. Studies, Problems, Solutions, 2003, vol. 6. P.16-17 [Совместно: Kolesnikov M.P., S.A.O.].

С.А.О. Моллюски в биогеохимических потоках $(\mathrm{C}, \mathrm{N}, \mathrm{P}, \mathrm{Si}, \mathrm{Al})$ и самоочищении воды: воздейсвтие ПАВ // Вестник МГУ. Сер. 16. Биология. 2003 № 1. С.15-24. Табл. Резюме на англ. яз. Библ. 59 назв. [Совместно: С.А.О., Колесников М.П.]. 


\begin{tabular}{|c|c|}
\hline иогеохимических потоков. & \\
\hline $\begin{array}{l}\text { Выделены основные биогеохимические блоки или } \\
\text { компоненты, концентрации химических } \\
\text { элементов в которых имеют существенное } \\
\text { значение для биогенной миграции элементов, в } \\
\text { том числе: 1) мягкие ткани моллюсков; 2) } \\
\text { раковины моллюсков; 3) фекалии; 4) } \\
\text { псевдофекалии; 5) слизистые вещества; 6) } \\
\text { продукты метаболизма, выделяемые в воду как } \\
\text { растворенные в ней вещества. Даны примеры их } \\
\text { количественного изучения. }\end{array}$ & $\begin{array}{l}\text { С.А.О. О роли моллюсков в биогенной миграции } \\
\text { элементов и самоочищении воды. - Ecol. Studies, } \\
\text { Hazards, Solutions, 2006, v. 11, c. 77-79, табл. } \\
\text { Библиогр. } 5 \text { назв. [Совместно: С.А.О., Ермаков } \\
\text { В.В., Зубкова Е.И., Колесников М.П., Колотилова } \\
\text { Н.Н., Крупина М.В.]; }\end{array}$ \\
\hline $\begin{array}{l}\text { Даны предложения к разработке концепции базы } \\
\text { данных для статистической модели оценки роли } \\
\text { моллюсков в биогенной миграции элементов, в } \\
\text { том числе металлов. Приводится список тех } \\
\text { величин и показателей, которые представляют } \\
\text { интерес для включения в такую базу данных. }\end{array}$ & $\begin{array}{l}\text { С.А.О. База данных для разработки } \\
\text { статистической модели оценки роли моллюсков в } \\
\text { биогенной миграции металлов: концепция и } \\
\text { разработка элементов теоретических основ. - } \\
\text { Ecol. Studies, Hazards, Solutions, 2006, v. 11, c. 79- } \\
\text { 83, табл. Библиогр. } 6 \text { назв. [Совместно: С.А.О., } \\
\text { Ермаков В.В., Зубкова Е.И., Колесников М.П., } \\
\text { Колотилова Н.Н., Крупина М.В., Лихачева Н.Е.]; }\end{array}$ \\
\hline $\begin{array}{l}\text { Role of molluscs in water self-purification and the } \\
\text { interactions between molluscs and elements, } \\
\text { including metals. }\end{array}$ & $\begin{array}{l}\text { Studying the role of molluscs in water self- } \\
\text { purification and the interactions between molluscs } \\
\text { and elements, including metals, in aquatic } \\
\text { environments. - ESHS, 2007, vol. 12, p. 29-32. } \\
\text { Bibliogr. } 9 \text { refs. [In collaboration: S.A.O., Zubcov } \\
\text { E.I., Toderash I.K., Biletchi L.I., Bogonina Z.S., } \\
\text { Breahna A., Klyushnikov V.Yu., Kolesnikov M.P., } \\
\text { Krupina M.V., Makarov A.S., Munjiu O.V., Railean } \\
\text { N., Subernetkii I.V.] }\end{array}$ \\
\hline Фосфор в мягких тканях Dreissena polymorpha. & $\begin{array}{l}\text { Фосфор в мягких тканях Dreissena polymorpha из } \\
\text { Дубоссарского водохранилища. - ESHS, 2007, } \\
\text { vol. 12, p. 51-53. [Совместно: Зубкова Е.И., } \\
\text { Тодераш И.К., Мунжиу О.В., С.А.О., Богонина } \\
\text { 3.С., Шубернецкий И.В.] }\end{array}$ \\
\hline $\begin{array}{l}\text { Разработка методологии [инкубацию Unio } \\
\text { pictorum вели 3,5 мес. в присутствии } 13 \text { металлов]. }\end{array}$ & $\begin{array}{l}\text { С.А.О. Изучение толерантности моллюсков в } \\
\text { условиях полиметаллического загрязнения воды } \\
\text { и длительной инкубации. - ESHS, 2007, vol. 12, p. } \\
\text { 78-81. }\end{array}$ \\
\hline $\begin{array}{l}\text { Обобщены данные мировой литературы о } \\
\text { содержании цинка в мягких тканях раковин } \\
\text { пресноводных и морских моллюсков, даны новые } \\
\text { результаты определения цинка в моллюсках, в } \\
\text { том числе водных экосистем р. Дон и Молдовы. }\end{array}$ & $\begin{array}{l}\text { Цинк в водных моллюсках // Известия АН } \\
\text { Молдовы. Науки о жизни. 2007, № 2, с. 102-114, } \\
\text { ISSN 1857-064Х. [совместно: Тодераш И.К., } \\
\text { С.А.О., Зубкова Е.И., Чернышёва И.В., Крупина } \\
\text { М.В., Микус А. А., Райлян Н.К., Бряхнэ А.И., } \\
\text { Мирон А.А., Кирошка В.В., Мунжиу О.В.]. }\end{array}$ \\
\hline $\begin{array}{l}\text { Среднее содержание ртути в мягких тканях } \\
\text { пресноводных двустворчатых моллюсков Unio } \\
\text { рictorum из одной из рек Московской области } \\
\text { составило } 181.2 \text { нг/л, в раковинах тех же } \\
\text { моллюсков - } 160.0 \text { нг/г. Уровень концентрации } \\
\text { ртути такого же порядка был ранее найден в } \\
\text { моллюсках ряда (но не всех) морских экосистем. }\end{array}$ & $\begin{array}{l}\text { Изучение содержания ртути в двустворчатых } \\
\text { моллюсках. - Экология окружающей среды и } \\
\text { безопасность жизнедеятельности = Екологія } \\
\text { довкілля та безпека життєдіятельності. №5, } 2007, \\
\text { с.79-80. } 2 \text { табл. Библиогр. } 6 \text { назв. [Совместно: } \\
\text { С.А.О., С.Д.Хушвахтова, В.Н. Данилова, В.В. } \\
\text { Ермаков]. }\end{array}$ \\
\hline Кадмий в моллюсках & $\begin{array}{l}\text { Изучение взаимодействия кадмия с водными } \\
\text { моллюсками в связи с экологическим } \\
\text { мониторингом // Вода: технология и экология. } \\
\text { 2007. № 3. С. 68-77. Табл. 3. Библиогр. } 41 \text { назв. } \\
\text { Реф. На русск. и англ. яз. с. 95. [Совместно: } \\
\text { C.A.O., Микус A.A.] [=Studying the interaction } \\
\text { between cadmium and aquatic molluscs in }\end{array}$ \\
\hline
\end{tabular}




\begin{tabular}{|c|c|}
\hline & $\begin{array}{l}\text { connection with ecological monitoring. - Water: } \\
\text { Technology and Ecology. 2007. No. 3. p. 68-77. } \\
\text { Tables, Bibliogr. } 41 \text { refs. (in Rus.) Abstracts in } \\
\text { English and Rus. P. 95]. }\end{array}$ \\
\hline Медь в гидробионтах & $\begin{array}{l}\text { Взаимодействие меди с гидробионтами в связи с } \\
\text { экологическим мониторингом и изучением роли } \\
\text { водных организмов в биогеохимических циклах // } \\
\text { Вода: технология и экология. 2007. № 4, с. 54-68. } \\
\text { ISSN 1993-8674 [Совместно: С.А.О., Е.И.Зубкова, } \\
\text { М.В.Крупина, А.А.Микус, И.К.Тодераш]. }\end{array}$ \\
\hline Металлы в раковинах перловиц Unio pictorum & $\begin{array}{l}\text { Изучение содержания металлов в раковинах } \\
\text { перловиц Unio pictorum. - ESHS, 2007, vol. 12, p. } \\
\text { 101-102. таб. Библиогр. } 5 \text { назв. [Совместно: } \\
\text { Пуховский А.В., С.А.О.] }\end{array}$ \\
\hline Металлы в моллюсках Unio pictorum & $\begin{array}{l}\text { Остроумов С.А., Колесов Г.М., Сапожников Д.Ю. } \\
\text { Металлы и вопросы гидробиологического } \\
\text { мониторинга: изучение содержания элементов в } \\
\text { моллюсках Unio pictorum методом нейтронно- } \\
\text { активационного анализа // Проблемы экологии и } \\
\text { гидробиологии / Ред. Тодераш И.К., Остроумов } \\
\text { С.А., Зубкова Е.И. 2008. М.: МАКС Пресс, с. 26- } \\
\text { 30. Библ. } 3 \text { назв. }\end{array}$ \\
\hline Ртуть в моллюсках & $\begin{array}{l}\text { Остроумов С.А., Хушвахтова С.Д., Данилова } \\
\text { В.Н., Ермаков В.В. Содержание ртути в } \\
\text { моллюсках Unio pictorum, Аnodonta, Viviparus } \\
\text { viviparous // Проблемы экологии и гидробиологии } \\
\text { / Ред. Тодераш И.К., Остроумов С.А., Зубкова } \\
\text { Е.И. 2008. М.: МАКС Пресс, с. 31-34. }\end{array}$ \\
\hline Свинец в моллюсках & $\begin{array}{l}\text { Микус А.А., Остроумов С.А., Свинец: опасность, } \\
\text { загрязнение среды, содержание в моллюсках // } \\
\text { Проблемы экологии и гидробиологии / Ред. } \\
\text { Тодераш И.К., Остроумов С.А., Зубкова Е.И. } \\
\text { 2008. М.: МАКС Пресс, с. 35-40. Библ. } 40 \text { назв. }\end{array}$ \\
\hline $\begin{array}{l}\text { Стронций в моллюсках (на примере девяти видов } \\
\text { моллюсков) }\end{array}$ & $\begin{array}{l}\text { Билецки Л.И., Зубков Е.И., Остроумов С.А., } \\
\text { Стронций в моллюсках (на примере девяти видов } \\
\text { моллюсков Кучурганского водоема-охладителя) // } \\
\text { Проблемы экологии и гидробиологии / Ред. } \\
\text { Тодераш И.К., Остроумов С.А., Зубкова Е.И. } \\
\text { 2008. М.: МАКС Пресс, с. 42-43. Библ. } 3 \text { назв. }\end{array}$ \\
\hline $\begin{array}{l}\text { Содержание элементов в пресноводных } \\
\text { моллюсках Unio методом нейтронно- } \\
\text { активационного анализа }\end{array}$ & $\begin{array}{l}\text { Остроумов С.А., Колесов Г.М., Сапожников Д.Ю. } \\
\text { К разработке вопросов гидробиологического } \\
\text { мониторинга водной среды: изучение содержания } \\
\text { элементов в моллюсках Unіо методом нейтронно- } \\
\text { активационного анализа // Проблемы экологии и } \\
\text { гидробиологии / Ред. Тодераш И.К., Остроумов } \\
\text { С.А., Зубкова Е.И. 2008. М.: МАКС Пресс, с. 47- } \\
\text { 53. }\end{array}$ \\
\hline $\begin{array}{l}\text { Содержание металлов } \mathrm{Cd}, \mathrm{Ni}, \mathrm{Cr}, \mathrm{An}, \mathrm{Mn}, \mathrm{Pb} \text { в } \\
\text { раковинах моллюсков Mytilus galloprovincialis) }\end{array}$ & $\begin{array}{l}\text { Клюшников В.Ю., Макаров А.С., Остроумов С.А. } \\
\text { Изучение содержания металлов Cd, Ni, Cr, An, } \\
\text { Mn, Pb в раковинах моллюсков Mytilus } \\
\text { galloprovincialis (Metals in the shells of Mytilus } \\
\text { galloprovincialis) // Проблемы экологии и } \\
\text { гидробиологии / Ред. Тодераш И.К., Остроумов } \\
\text { С.А., Зубкова Е.И. 2008. М.: МАКС Пресс, с. 54- } \\
\text { 56. Библ. } 4 \text { назв. }\end{array}$ \\
\hline
\end{tabular}


Роль макрофитов пресноводных экосистем в накоплении металлов

Роль моллюсков в биогенной миграции металлов изучение мягких тканей Dreissena polymorpha
Роль моллюсков в биогенной миграции фосфора:

Зубкова Е.И., Билецки Л.И., Мунжиу О.В., Остроумов С.А., Шубернецкий И.В. Роль макрофитов пресноводных экосистем в накоплении металлов (на примере Дубоссарского водохранилища) // Проблемы экологии и гидробиологии / Ред. Тодераш И.К., Остроумов С.А., Зубкова Е.И. 2008. М.: МАКС Пресс, с. $63-$ 64.

Зубкова Е.И., Тодераш И.К., Остроумов С.А., Билецки Л.И., Мунжиу О.В., Шубернецкий И.В. Значение моллюсков в биогенной миграции металлов и влияние металлов на жизнь донных гидробионтов // Проблемы экологии и гидробиологии / Ред. Тодераш И.К., Остроумов С.А., Зубкова Е.И. 2008. М.: МАКС Пресс., с. 64 66.

Зубкова Е.И., Тодераш И.К., Мунжиу О.В., Остроумов С.И., Богинина 3.С., Шубернецкий И.В. Роль моллюсков в биогенной миграции фосфора: изучение мягких тканей Dreissena polymorpha из Дубоссарского водохранилища // Проблемы экологии и гидробиологии / Ред. Тодераш И.К., Остроумов С.А., Зубкова Е.И. 2008. М.: МАКС Пресс., с. 67-68.

Элементы в раковинах моллюсков Viviparus viviparus: изучение методом нейтронноактивационного анализа

Изучали изменения концентраций тяжелых металлов в воде экспериментальных систем. Концентрация тяжелых металлов $\mathrm{Cu}, \mathrm{Zn}, \mathrm{Cd}, \mathrm{Pb}$ в воде экспериментальных микрокосмах змеряли методом инверсионной вольтамперометрии. В микрокосмах инкубировали макрофиты Ceratophyllum demersum. Измеряемые этим методом концентрации металлов в микрокосмах с макрофитами снижались значительно быстрее, чем в контрольных микрокосмах без растений. Новые результаты дополняют ранее полученные данные о фиторемедиационном потенциале водных растений (Вестник Моск. ун-та. Сер. 16. Биология. - 2007. - № 4. - C.39-42). Changes in the concentration of heavy metals in the water of experimental systems were studied. Using the method of inversion voltamperometry, the concentrations of the heavy metals $\mathrm{Cu}, \mathrm{Zn}, \mathrm{Cd}, \mathrm{Pb}$ were measured in the water of the experimental microcosms. Aquatic macrophytes Ceratophyllum demersum were in the water of the experimental microcosms. The measured concentrations of all four heavy metals decreased in the microcosms with the macrophytes much faster
Остроумов С.А., Колесов Г.М., Сапожников Д.Ю. Содержание элементов в раковинах моллюсков моллюсков Viviparus viviparus: изучение методом нейтронно-активационного анализа // Ecological Studies, Hazards, Solutions. 2009. V. 13, p. 113-117. [= Ostroumov S.A., Kolesov G.M., Sapozhnikov D.Yu. The content of chemical elements in the shells of molluscs Viviparus viviparus: a study by the method of neutron activation analysis // Ecological Studies, Hazards, Solutions. 2009. 13: 113-117]. Остроумов С.А., Шестакова Т.В., Котелевцев С.В., Соломонова Е.А., Головня Е.Г., Поклонов В.А. Присутствие макрофитов в водной системе ускоряет снижение концентраций меди, свинца и других тяжелых металлов в воде. // Водное хозяйство России. 2009. №. 2. с. 58 - 67. Табл., Библиогр. 17 назв. [=Ostroumov S.A., Shestakova T.V., Kotelevtsev S.V., Solomonova E.A., Golovnya E.G., Poklonov V.A. Presence of the macrophytes in aquatic system accelerated a decrease in concentrations of copper, lead and other heavy metals in water. // Water Sector of Russia: Problems, Technologies, Management (=Vodnoe Khozyaistvo Rossii). 2009. No. 2. p. 58 - 67. Bibliogr. 17 refs. 
than in the control microcosms without any aquatic plants. The new results complement the previous data on the phytoremediation potential of aquatic plants (Vestnik Moskovskogo Universiteta. Series 16/ Biology. 2007. - № 4. - C.39-42)].

Измерены концентрации элементов в бурых водорослях Cystoseira crinita из Черного моря. Концентрации уменьшались в следующем порядке: $\mathrm{Fe}>\mathrm{Zn}>\mathrm{Mn}>\mathrm{Cr}>\mathrm{As}>\mathrm{Cu}>\mathrm{Pb}>\mathrm{Cd}>$ Co. Данные согласуются с предложенной теорией полифункциональной роли биоты в контроле качества воды и ее самоочищении (ДАН, 2004, T.396. С.136-141; Экология, №. 6, 2005, с. 452459)].

Впервые выявлено нарастание содержания металлов в фитомассе после инкубации в водной среде с наночастицами оксидов металлов.

Остроумов С.А., Демина Л.Л. Экологическая биогеохимия и элементы (As, $\mathrm{Co}, \mathrm{Fe}, \mathrm{Mn}, \mathrm{Zn}, \mathrm{Cu}$, $\mathrm{Cd}, \mathrm{Cr}$ ) в цистозире и биогенном детрите в морской модельной экосистеме: определение методом атомно-абсорбционной спектрометрии (AАC) // Экологические системы и приборы. 2009. № 9, c.42-45.

M.E. Johnson, S.A. Ostorumov, J. F. Tyson, B. Xing, Measuring the concentrations of elements including toxic metals in phytomass after incubation of aquatic macrophytes with nanoparticles of metal oxides // Фундаментальные и инновационные аспекты биогеохимии. Материалы VII биогеохимической школы. 12 - 15 сентября 2011 г. АстраханьМосква. Москва. 2011, ГЕОХИ. С.66-69.

Immobilization of heavy metal (copper and others) by biomass of macrophytes, after their incubation with nanoparticles $\mathrm{Cu}$ oxides and other metal oxides

Иммобилизация тяжелого металла (на примере меди) биомассой макрофитов

Ostroumov S.A., Podchernyaeva R. Ya., Suetina I. A., Lopatina O. A., Johnson M.E., Tyson J. F., Xing B. Interactions of nanoparticles of $\mathrm{Cu}$ oxides and other metal ozides with biological objects.

The 2nd International School "Nanomaterials and nanotechnology in living systems. Safety and nanomedicine" (September 19-24, 2011). Moscow. p.142
Иммобилизация меди фитомассой макрофитов биогенным материалом

Повышение концентрации меди в биомассе макрофитов после инкубации в водной среде, содержащей наночастицы оксида меди.

M.E. Johnson, S.A. Ostorumov, J. F. Tyson, B. Xing. On the biogeochemistry and geochemical ecology of nanotechnology products: interactions of metal oxide nanoparticles with macrophytes and plant-derived materials // Проблемы биогеохимии и геохимической экологии, 2011, № 3 (17). С. 136148.

M.E. Johnson, S.A. Ostorumov, J. F. Tyson, B. Xing, Study of the Interactions between Elodea canadensis and $\mathrm{CuO}$ Nanoparticles. 2011, published in Ekologicheskaya Khimiya, 2011, Vol. 20, No. 4, pp. 189-194. In Rus.

М. Джонсон, С.А. Остроумов, Дж.Ф.Тайсон, Б. Шин. Изучение взаимодействий Elodea canadensis и наночастиц $\mathrm{CuO} / /$ Экологическая химия, 2011, т. 20, № 4, стр. 189-194

Cover is one of the key heavy metals that pollute environment. Copper may enter the aquatic environment in both soluble and nanoparticle form. It was previously found in a series of studies that nanoparticles, including those of several metal oxides, exercise both negative and positive effects on the higher plants which makes necessary further
Johnson M. E., S. A. Ostroumov, J. F. Tyson and B. Xing. Study of the interactions between Elodea canadensis and $\mathrm{CuO}$ nanoparticles // Russian Journal of General Chemistry, 2011.Volume 81, Number 13, 2688-2693, DOI:10.1134/S107036321113010X

[Pleiades Publishing, Ltd. Distributed worldwide by 
research on the interaction between metal oxide nanoparticles and plants. Interaction between aquatic plants and copper-containing nanoparticles were not sufficiently studied. The goal of this study was the investigation of the interactions between $\mathrm{CuO}$ nanoparticles and the aquatic plant Elodea canadensis in experimental microcosms. It was found that $\mathrm{CuO}$ nanoparticles demonstrated some phytotoxicity to Elodea canadensis. After the incubation of Elodea canadensis in the aquatic medium contaminated with $\mathrm{CuO}$ nanoparticles there was a significant increase (by two orders of magnitude) of the concentration of copper in the biomass of the plants. In English.

Иммобилизация тяжелых металлов и других токсичных элементов образцами биомассы биогенного материала

[S.A. Ostroumov 1, S.V. Kotelevtsev 1, V.M. Glaser 1, O.M. Gorshkova 1, E.A. Gushina 2, M.E. Johnson 3, V.V. Ermakov 4, A.E. Zhbanov 1, E.I. Zubkova5, L. Jovanovic 6, O.A. Lopatina2, D.N.Matorin1, M.S. Panin7, R. Ya. Podchernyaeva 2, V.A. Poklonov 1, A.P. Sadchikov 1, A.A. Soldatov 8, E.A. Solomonova 1, I.A. Suetina 2, J. F. Tyson 3, I.K. Toderas 5, V.L. Sheleykovsky 9, T. V. Shestakova 1, B. Xing 3. Chemical-biotic interactions in systems with heavy metals and other pollutants: towards innovative ecotechnology].
Springer. Russian Journal of General Chemistry ISSN 1070-3632]
С.А. Остроумов, С.В. Котелевцев, В.М. Глазер, О.М. Горшкова, Е.А. Гущина, М.Е. Джонсон, В.В. Ермаков, А.Е. Жбанов, Е.И. Зубкова, Л. Йованович, О.А. Лопатина, Д.Н. Маторин, М.С. Панин, Р.Я. Подчерняева, В.А. Поклонов, А.П. Садчиков, А.А. Солдатов, Е.А. Соломонова, И.А. Суетина, Дж.Ф.Тайсон, И.К. Тодераш, В.Л. Шелейковский, Т.В. Шестакова, Б. Шин. Химикобиотические взаимодействия в системах с тяжелыми металлами и другими поллютантами: к инновационной экотехнологии // Тяжелые металлы и радионуклиды в окружающей среде. Материалы VII Международной научнопрактической конференции (Семипалатинск, 4 8 октября 2012 года). Т. I. - Семей:

Семипалатинский гос. педагогический ин-т, 2012, c.471-476 (всего в сборнике 519 с.) ISBN 978-6017332-72-3.

В различных вариантах эксперимента впервые измерены концентрации редкоземельных элементов в образцах мортмассы нескольких видов макрофитов (в рабте участвовали ученые университета Массачусетса, США).

Выявлена способность биогенного материала (мортмассы макрофитов) иммобилизовывать тяжелые металлы и редкоземельные элементы.

Мортмасса Myriophyllum aquaticum иммобилизует палладий, скандий, титан, цирконий, уран и другие элементы, находящиеся в водной среде в растворенном виде и в форме наночастиц.
С.А.Остроумов. Живое вещество и роль детрита в биогенной миграции микроэлементов (Глава 3). В книге: Инновационные аспекты биогеохимии. 2012. Москва, ГЕОХИ. / Ред. акад. М.А. Федонкин, С.А.Остроумов.
Ostroumov S.A., M.E.Johnson, J.F.Tyson, B.Xing.

Мортмасcа Myriophyllum aquaticum иммобилизует палладий, скандий, титан, цирконий, уран и другие элементы, находящиеся в водной среде в растворенном виде и в форме наночастиц. // Материалы Биогеохимических чтений (2012), Отв. редактор проф. В.В.Ермаков.

Вышеприведенная таблица суммирует лишь часть публикаций по данной теме.

Анализ содержащихся в таблице работ показывает следующее: 1 . Получены новые данные о содержании химических элементов в конкретных видах организмов. Среди изученных видов организмов значительное место занимают гидробионты. 
2. В ряде случаев информация о содержании химических элементов дифференцирована с учетом определений, проведенных для различных частей организмов (например, получены новые данные о химическом составе раковин моллюсков.

3. Наряду с определением фоновых концентраций химических элементов измеряли также результаты сорбции и биосорбции химических элементов биогенным материалом в условиях экспериментов. В качестве биогенного материала, для которого измеряли способность к сорбции и биосорбции, использовали не только биомассу, но и мортмассу.

4. Те химические элементы, концентрации которых измеряли, относятся к нескольким группам. Среди них - традиционно изучаемые металлы (в том числе из группы так называемых тяжелых металлов), редкоземельные элементы и некоторые другие. Существенно, что некоторые из этих элементов привлекают к себе внимание как опасные загрязнители биосферы (например, ртуть).

5. Некоторые из изученных элементов имеют значение как факторы эвтрофикации (азот, фосфор), что важно для разработки практических мер по борьбе с эвтрофированием.

Значительная информация содержится также и в других публикациях многих авторов.

Приведем лишь некоторые из них.

Существенный вклад внесли работы ученых РАН - члена-корреспондента РАН Т.И. Моисеенко, Е.И. Коробовой, В.В. Ермакова, члена-корреспондента РАН Э.В. Ивантера, Л.Л .Деминой и многих других ученых. Подробнее о некоторых из этих работ ниже, а также в цитируемой библиографии.

Таблица 2 Результаты в публикациях члена-корреспонента РАН Т.И. Моисеенко и соавт. (некоторые примеры).

\begin{tabular}{|l|l|l|}
\hline год & Комментарии & Публикации \\
\hline 1997 & $\begin{array}{l}\text { Данные о концентрации и накоплении многих } \\
\text { химических элементов в организме пресноводных } \\
\text { гидробионтов }\end{array}$ & $\begin{array}{l}\text { Моисеенко, Т. И., Даувальтер, В. } \\
\text { А Родюшкин, И. В. (1997). } \\
\text { Геохимическая миграция } \\
\text { элементов в субарктическом } \\
\text { водоеме (на примере озера } \\
\text { Имандра). Апатиты: Изд-во КНЦ } \\
\text { РАН. }\end{array}$ \\
\hline 2016 & $\begin{array}{l}\text { Данные о концентрации и накоплении ртути в } \\
\text { организме рыб многих таксонов }\end{array}$ & $\begin{array}{l}\text { Моисеенко, Т. И., апд Н. А. } \\
\text { Гашкина. "Биоаккумуляция ртути } \\
\text { в рыбах как индикатор уровня } \\
\text { загрязнения вод." Геохимия 6 } \\
\text { (2016): 495-504. }\end{array}$ \\
\hline 2018 & $\begin{array}{l}\text { Данные о концентрации и накоплении кадмия в } \\
\text { организме многих таксонов в связи } \\
\text { токсичностью этого химического элемента и } \\
\text { загрязнением среды }\end{array}$ & $\begin{array}{l}\text { Моисеенко Т. И., Гашкина Н. А. } \\
\text { Биогеохимия кадмия: } \\
\text { антропогенное рассеивание, } \\
\text { биоаккумуляция и } \\
\text { экотоксичность //Геохимия. - } \\
\text { 2018. - №. 8. - С. 759-773. }\end{array}$ \\
\hline 2019 & $\begin{array}{l}\text { Данные о концентрации и накоплении металлов в } \\
\text { организме многих таксонов в связи } \\
\text { токсичностью этих химического элемента, } \\
\text { загрязнением среды, и вопросами } \\
\text { биодоступности металлов }\end{array}$ & $\begin{array}{l}\text { Моисеенко, Т. И. (2019). } \\
\text { Биодоступность и экотоксичность } \\
\text { металлов в водных системах: } \\
\text { критические уровни загрязнения. } \\
\text { Геохимия, 64(7), 675-688. }\end{array}$ \\
\hline
\end{tabular}




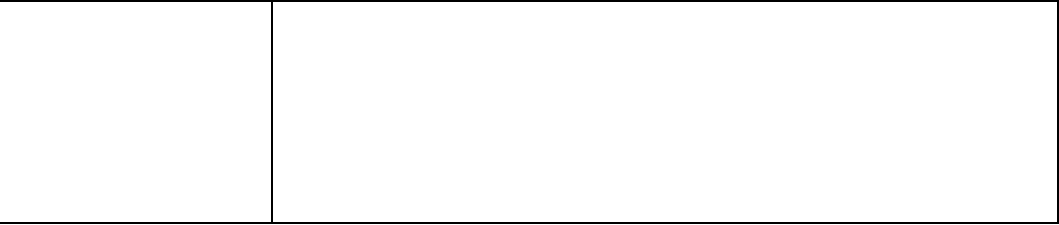

Существенный объем новых данных получен и проанализирован в книгах и статьях д.б.н. В.В.Ермакова (Институт геохимии и аналитической химии РАН). Примеры - ниже в Таблице 3.

Таблица 3 Результаты в публикациях В.В.Ермакова и соавт. (некоторые примеры)

\begin{tabular}{|c|c|c|}
\hline Химические элементы & Комментарии & Публикации \\
\hline Селен & $\begin{array}{l}\text { Получены данные о } \\
\text { концентрации и накоплении } \\
\text { селена в организмах многих } \\
\text { таксонов, показана большая } \\
\text { роль селена в метаболизме }\end{array}$ & $\begin{array}{l}\text { Ермаков, В. В., \& Ковальский, В. } \\
\text { В. (1974). Биологическое } \\
\text { значение селена. }\end{array}$ \\
\hline Многие химические элементы & $\begin{array}{l}\text { Получены и систематизированы } \\
\text { данные о концентрации и } \\
\text { накоплении металлов и других } \\
\text { химических элементов в } \\
\text { животных многих таксонов }\end{array}$ & $\begin{array}{l}\text { Ермаков, В. В., \& Тютиков, С. Ф. } \\
\text { (2008). Геохимическая экология } \\
\text { животных. } \\
\text { М.,Наука/Интерпериодика". }\end{array}$ \\
\hline Многие химические элементы & $\begin{array}{l}\text { систематизированы данные о } \\
\text { концентрации и накоплении } \\
\text { металлов и других химических } \\
\text { элементов в организмах многих } \\
\text { таксонов, во многих объектах } \\
\text { геохимической среды ( в том } \\
\text { числе в почвах и океане) }\end{array}$ & $\begin{array}{l}\text { Ермаков, В. В., Карпова, Е. А., } \\
\text { Корж, В. Д., \& Остроумов, С. А. } \\
\text { (2012). Инновационные аспекты } \\
\text { биогеохимии. }\end{array}$ \\
\hline $\begin{array}{l}\text { металлы и другие химические } \\
\text { элементы }\end{array}$ & $\begin{array}{l}\text { в организмах многих таксонов, } \\
\text { во многих объектах } \\
\text { геохимической среды }\end{array}$ & $\begin{array}{l}\text { Ермаков, В. В. (2015). } \\
\text { Геохимическая экология и } \\
\text { биогеохимические критерии } \\
\text { оценки экологического } \\
\text { состояния таксонов биосферы. } \\
\text { Геохимия, (3), 203-221. }\end{array}$ \\
\hline металлы & $\begin{array}{l}\text { Получены и систематизированы } \\
\text { данные о концентрации и } \\
\text { накоплении металлов в элодее } \\
\text { канадской }\end{array}$ & $\begin{array}{l}\text { Остроумов, С. А., Данилова, В. } \\
\text { Н., Хушвахтова, С. Д., Ермаков, } \\
\text { В. В., Тютиков, С. Ф., Тропин, И. } \\
\text { В., \& Котелевцев, С. В. (2016). } \\
\text { Содержание химических } \\
\text { элементов, глутатиона и } \\
\text { металлотионеинов в элодее } \\
\text { канадской (Еlodea canadensis) в } \\
\text { связи с экологическим } \\
\text { мониторингом. Экологическая }\end{array}$ \\
\hline
\end{tabular}




\begin{tabular}{|l|l|l|}
\hline & & химия, 25(4), 197-203. \\
\hline Ртуть & $\begin{array}{l}\text { Систематизированы данные о } \\
\text { концентрации и накоплении } \\
\text { ртути в организмах многих } \\
\text { таксонов, во многих объектах } \\
\text { геохимической среды }\end{array}$ & $\begin{array}{l}\text { Данилова, В. Н., Хушвахтова, С. } \\
\text { С. А. (2018). Биогеохимические } \\
\text { aспекты аккумулирования ртути } \\
\text { в биосфере. In Труды } \\
\text { Всероссийского ежегодного } \\
\text { семинара по экспериментальной } \\
\text { минералогии, петрологии и } \\
\text { геохимии (рр. 394-396). }\end{array}$ \\
\hline
\end{tabular}

Дополнительно к изложенному выше, приедем еще примеры работ по определению концентрации химических элементов в биомассе организмов - на примере растений. См. таблицу 4 ниже.

Таблица 4 . Результаты измерения содержания некоторых из изученных в данной работе элементов в образцах растительного материала (данные различных авторов).

\begin{tabular}{|c|c|c|c|}
\hline Элементы & $\begin{array}{l}\text { Образцы } \\
\text { материала } \\
\text { растений }\end{array}$ & $\begin{array}{l}\text { Концентрации } \\
\text { На сухой вес }\end{array}$ & Ссылки \\
\hline $\begin{array}{l}\text { Палладий } \\
\text { Pd }\end{array}$ & Pinus radiate & $\begin{array}{l}15 \pm 15 \text { ррь в золе. } \\
\text { Зола составляла } 3 \% \\
\text { от сухого веса } \\
\text { образцов. }\end{array}$ & $\begin{array}{l}\text { Kothny E.L. Palladium in plant ash. // Plant and Soil. } \\
\text { 1979. Vol.53. P.547-550. }\end{array}$ \\
\hline $\begin{array}{l}\text { Скандий } \\
\text { Sc }\end{array}$ & $\begin{array}{l}\text { Различные } \\
\text { виды }\end{array}$ & $\begin{array}{l}\text { Из многих } \\
\text { исследованных } \\
\text { образцов различных } \\
\text { видов растений лишь } \\
\text { в } 3 \% \text { содержание } \\
\text { было выше предела } \\
\text { обнаружения. } \\
\text { Обнаруженные } \\
\text { концентрации были } \\
\text { на уровне } \\
\text { нескольких мкг/ кг } \\
\text { (ррb). }\end{array}$ & $\begin{array}{l}\text { Scandium. Chemical properties of scandium. Health } \\
\text { effects of scandium. Environmental effects of } \\
\text { scandium. } \\
\text { http://www.lenntech.com/periodic/elements/sc.htm; }\end{array}$ \\
\hline Титан Тi & $\begin{array}{l}\text { Diandrostach } \\
\text { ia chrysotrix, } \\
\text { Erythroxylum } \\
\text { sp., Leandra } \\
\text { aurea }\end{array}$ & $3-9,5 \mathrm{mg} / \mathrm{kg}$ & $\begin{array}{l}\text { Ceccantini G., Figueiredo A.M.G., Sondag F., Soubies } \\
\text { F. Rare earth elements and titanium in plants. soils and } \\
\text { groundwaters in the alkaline-ultramafic complex of } \\
\text { Salitre, MG, Brazil // Contaminated Soils. 3rd } \\
\text { international Conference on the Biogeochemistry of } \\
\text { Trace Elements. Paris (France). May 15-19, 1995; } \\
\text { http://horizon.documentation.ird.fr/exl- } \\
\text { doc/pleins_textes/pleins_textes_7/b_fdi_51- } \\
\text { 52/010015618.pdf }\end{array}$ \\
\hline
\end{tabular}




\begin{tabular}{|c|c|c|c|}
\hline $\begin{array}{l}\text { Цирконий } \\
\mathrm{Zr}\end{array}$ & $\begin{array}{l}\text { Томаты, } \\
\text { корни } \\
\text { Lycopersicon } \\
\text { esculentum } \\
\text { L. }\end{array}$ & $\begin{array}{l}\text { 2,60-7,96 мг/кг } \\
\text { (выращивали на } \\
\text { почве); 2,84 мг/кг } \\
\text { (гидропоника) }\end{array}$ & $\begin{array}{l}\text { Ferrand E., Benedetti M. F., Leclerc-Cessac E., and } \\
\text { Dumat C. Study of the mechanisms involved in the } \\
\text { rhizosphere for the absorption of zirconium by } \\
\text { vegetables // Difpolmine Conference. 12-14 December } \\
\text { 2006. Le Corum - Montpellier, France. } \\
\text { http://www.ademe.r/difpolmine/Difpolmine_RapportF } \\
\text { inal/communication/12_13_posters- } \\
\text { Corum/Difpolmine_Poster13_Dumat_proceeding.pdf }\end{array}$ \\
\hline $\mathrm{Zr}$ & $\begin{array}{l}\text { Горох, } \\
\text { корни Pisum } \\
\text { sativum }\end{array}$ & $\begin{array}{l}\text { 1,08-1,15 (на почве); } \\
0,58 \text { (гидропоника) }\end{array}$ & $\begin{array}{l}\text { Ferrand E., Benedetti M. F., Leclerc-Cessac E., and } \\
\text { Dumat C. Study of the mechanisms involved in the } \\
\text { rhizosphere for the absorption of zirconium by } \\
\text { vegetables // Difpolmine Conference. 12-14 December } \\
\text { 2006. Le Corum - Montpellier, France. } \\
\text { http://www.ademe.r/difpolmine/Difpolmine_RapportF } \\
\text { inal/communication/12_13_posters- } \\
\text { Corum/Difpolmine_Poster13_Dumat_proceeding.pdf }\end{array}$ \\
\hline $\begin{array}{l}\text { Палладий, } \\
\text { скандий, } \\
\text { цирконий, } \\
\text { титан }\end{array}$ & $\begin{array}{l}\text { Myriophyllu } \\
\text { m aquaticum }\end{array}$ & $\begin{array}{l}\text { Содержание } \\
\text { элементов в } \\
\text { мортмассе } \\
\text { Myriophyllum } \\
\text { aquaticum - см. } \\
\text { текст публикации } \\
\text { (ссылка справа) }\end{array}$ & $\begin{array}{l}\text { Остроумов С. А. Химико-биологические } \\
\text { взаимодействия и новое в учении о биосфере В.И. } \\
\text { Вернадского. Москва, МАКС-Пресс. 2013. } 92 \text { с. }\end{array}$ \\
\hline
\end{tabular}

Заключение: Актуальность вопроса о судьбе изученных элементов в окружающей среде (в том числе вопрос о накоплении их в организмах) связана с их практическим использованием в промышленности и производстве различных изделий и материалов, что неизбежно создает новые виды загрязнения окружающей среды, в том числе водных объектов.

Новые данные, упомянутые выше, открывают путь к более глубокому познанию биогеохимических потоков химических элементов в окружающей среде, к дополнительному пониманию того, что В.И.Вернадский назвал биогенной миграцией атомов химических элементов.

Полученная новая информация о накоплении химических элементов в организмах будет способствовать: (1) более глубокому пониманию фундаментальных проблем геохимии и биогеохимии, химической и биохимической экологии; (2) поиску путей решения проблем химического загрязнения биосферы.

\section{ЛИТЕРАТУРА}

1. Абакумов В.А. Инновационные подходы к восстановлению и ремедиации загрязненных водных объектов // Вода: технология и экология. 2007. № 4. С.69-73.

2. Абакумов В.А. Новое о ремедиации и восстановлении загрязненных водных систем // Проблемы биогеохимии и геохимической экологии. 2007, № 2 (4), с. 98 100.

3. Алимов А.Ф. Функциональная экология пресноводных двустворчатых моллюсков. Л.: Наука, 1981. 248 с.; Элементы теории функционирования водных экосистем. Санкт-Петербург: Наука. 2000. 147 с. 
4. Биологический контроль окружающей среды: биоиндикация и биотестирование» / Ред. О.П. Мелехова, Е.И. Сарапульцева. М.: Издательский центр «Академия» 2008, 288 с. ISBN 978-5-7695-5594-7. 2-е изд., испр.

5. Брагинский Л.П., Л.А. Сиренко. Всесторонний анализ токсикологической опасности поверхностно - активных веществ для гидробионтов. Гидробиологический журнал. 2003, т. 39, № 3, с. 115 -118.

6. Брагинский Л.П., К.П. Калениченко, А.А. Игнатюк. Обобщенные механизмы самоочищения природных вод. // Гидробиологическ журнал. - 2007. - т.43, № 6. C. 111- 113.

7. Вернадский В.И. Биосфера. М.: Издательский дом "Ноосфера", 2001. - 243 с.

8. Вернадский В. И. Химическое строение биосферы Земли и её окружения. Москва. Наука, 1965. 374 с.

9. Вернадский В.И., Биосфера и ноосфера. М.: Наука.1989, 261 с.

10. Галимов Э.М. Природа биологического фракционирования изотопов. М. Наука. 1981. $247 \mathrm{c}$.

11. Гордеев В.В. Лисицын А.П. Микроэлементы. В кн.: Химия океана.т.1. М.: Наука, 1979. С.337-375.

12. Демина Л.Л. Формы миграции тяжелых металлов в океане. М.: Наука.1982. 120 с.

13. Добровольский Г.В. О развитии некоторых концепций учения о биосфере // Вода: технология и экология. 2007. № 1. С. 63-68.

14. Добровольский Г.В. К 80-летию выхода в свет книги В.И. Вернадского "Биосфера". Развитие некоторых важных разделов учения о биосфере // Экологическая химия. 2007. т.16(3). С.135-143.

15. Добровольский Г.В., Г.С. Розенберг, И.К. Тодераш. (ред). Открытие нового вида опасных антропогенных воздействий в экологии животных и биосфере: ингибирование фильтрационной активности моллюсков поверхностно-активными веществами. Москва: МАКС-Пресс, 2008, 108 с., ISBN 978-5-317-02370-6.

16. Донченко В.К., Иванова В.В., Питулько В.М. Эколого-химические особенности прибрежных акваторий. Спб. НИЦЭБ РАН. 2008. 544 с.

17. Ермаков В.В. Техногенез и биогеохимическая эволюция таксонов биосферы (Technogenesis and biogeochemical evolution of the biospheric taxons).- М: Наука. 2003. - $351 \mathrm{c}$.

18. Ермаков В.В. Изучение взаимодействия загрязняющих веществ с водными организмами // Вода: технология и экология. 2009. №2. стр. 69 - 73.

19. Ермаков В.В., Тютиков С.Ф. Химический состав живого вещества. // Проблемы биогеохимии и геохимической экологии. 2008. № 3 (7). С.3-16.

20. Ермаков В.В., Тютиков С.Ф. Геохимическая экология животных. М.: Наука. 2008. $315 \mathrm{c}$.

21. Жиров В.К. Поиск фитотехнологий для очищения воды // Проблемы биогеохимии и геохимической экологии, 2008, №3 (7), с.155-156.

22. Жиров В.К. О новых исследованиях взаимодействия загрязняющих веществ с макрофитами в связи с изучением их фиторемедиационного потенциала // Вода: технология и экология. 2009. № 1. стр. 72-74.

23. Ивантер Э.В., Медведев Н.В. Экологическая токсикология природных популяций. М.: Наука. 2007. 229 с.

24. Корж В.Д. Геохимия элементного состава гидросферы. М. Наука. 1991. 244 с. 
25. Котелевцев С. В., Стволинский С.Л., Бейм А.М. Эколого-токсикологический анализ на основе биологических мембран. - М.: МГУ, 1986. -105 с.

26. Криксунов Е.А. Новое в изучении современных проблем экологии, гидробиологии и наук об окружающей среде. - Экология окружающей среды и безопасность жизнедеятельности. 2006, № 6. стр. 93.

27. Митропольский А.Ю. Environment Ecology and Safety of Life Activity (='Ecology of surroundings and safety of vital activity', “Экология окружающей среды и безопасность жизнедеятельности”). 2007. №5. с.81-85. ISSN 1726-5428.

28. Остроумов С.А. Всемирная стратегия охраны природы // Природа. 1980. № 12. C.40-41.

29. Остроумов С.А. Загрязнение воздуха изменяет проницаемость мембран растительных клеток // Природа. 1980. № 3, с. 115.

30. Остроумов С.А. Химия экологических связей между организмами. Рец. на книгу: М. Барбье "Введение в химическую экологию" М.: Мир. 1978 // Бюллетень МОИП. Отд. биол. 1980. т.85. вып. 4. С.123-125.

31. Остроумов С.А. Введение в биохимическую экологию. 1986. М.: Изд-во Московского университета. $176 \mathrm{c}$.

32. Остроумов С.А. Биологические эффекты поверхностно-активных веществ в связи с антропогенными воздействиями на биосферу. М.: МАКС-Пресс. 2000. 116 с. ISBN 5-317-00040-8. Предисловие академика М.Е. Виноградова.

33. Остроумов С.А. Биологические эффекты при воздействии поверхностно-активных веществ на организмы. М.: МАКС-Пресс. 2001. Х. 334 с. ISBN 5-317-00323-7. Предисловие академика М.Е. Виноградова.

34. Остроумов С.А. Сохранение биоразнообразия и качество воды: роль обратных связей в экосистемах. // Доклады Академии наук. 2002. Т. 383. № 1. С. 138.

35. Остроумов С.А. Биологический механизм самоочищения в природных водоемах и водотоках: теория и приложения // Успехи современной биологии. 2004. Т. 124. № 5. С. 429.

36. Остроумов С.А. О биотическом самоочищении водных экосистем. Элементы теории // Доклады Академии наук. 2004. Т. 396. № 1. С. 136.

37. Остроумов С.А. О некоторых вопросах поддержания качества воды и ее самоочищения // Водные ресурсы. 2005. Т. 32. № 3. С. 337-346.

38. Остроумов С.А. Ингибиторный анализ регуляторных взаимодействий в трофических цепях // Доклады Академии наук. 2000. Т. 375. № 6. С. 847.

39. Остроумов С.А. Синэкологические основы решения проблемы эвтрофирования// Доклады Академии наук. 2001. Т. 381. № 5. С. 709.

40. Остроумов С.А. О полифункциональной роли биоты в самоочищении водных экосистем // Экология. 2005. № 6. С. 452-459. Остроумов С.А. Биотический механизм самоочищения пресных и морских вод. Элементы теории и приложения $=$ Biotic mechanism of self-purification of freshwater and marine water.M.: MAKC Пресс. 2004. 96 c. ISBN 5-317-01120-5.

41. Остроумов С.А. Загрязнение, самоочищение и восстановление водных экосистем = Pollution, self-purification and restoration of aquatic ecosystems. М.: МАКС Преcc. 2005. 100 c. ISBN 5-317-01213-9.

42. Остроумов С.А. Геохимический аппарат водных экосистем: биокосная регуляция // Вестник РАН. 2004. Т.74. № 9. С.785-791.

43. Остроумов С.А. Гидробиологическое самоочищение вод: от изучения биологических механизмов к поиску экотехнологий (Серия «Академические 
чтения», вып. 48) - М.: ФГУП Изд-во «Нефть и газ» РГУ нефти и газа им. И.М. Губкина, 2007. - 52 с.

44. Остроумов С.А. Биологические фильтраторы - важная часть биосферы // Наука в России. 2009. № 2. с. 30-36.

45. Остроумов С.А. Гидробионты в самоочищении вод и биогенной миграции элементов. М. МАКС-Пресс. 2008. 200 с. Предисловие акад. РАН В.В.Малахова. ISBN 978-5-317-02625-7.

46. Перельман А.И., Касимов Н.С. 2000. Геохимия ландшафта: - М.: Астрея-2000. $763 \mathrm{c}$.

47. Проблемы экологии и гидробиологии / Ред. И.К. Тодераш, С.А. Остроумов, Е.И. Зубкова. Москва, МАКС пресс. 2008. - 80 с. ISBN 978-5-317-02224-2.

48. Розенберг Г.С. «Экология в картинах (учебное пособие)». Тольятти: ИЭВБ РАН, 2007, c.146. ISBN 978-5-93424-298-6.

49. Розенберг Г.С., Мозговой Д.П., Гелашвили Д.Б. Экология: элементы теоретических конструкций современной экологии. Самара: Самарский научн. центр РАН.1999. $396 \mathrm{c.}$

50. Романенко В.Д., Романенко А.В. На стыке наук. - Гидробиол. журнал. 1992. -Т. 28. № 2. - С. 82 - 83 .

51. Скулачев В.П. Энергетика биологических мембран. 1989, 564 с.

52. Телитченко М.М., Остроумов С.А. Введение в проблемы биохимической экологии. М.: Наука. 1990. 288 с. ISBN 5-02-004062-2 (= Introduction to Problems of Biochemical Ecology: Biotechnology, Agriculture, Environment).

53. Федонкин М.А.. Об исследованиях связи вопросов самоочищения воды и биогенной миграции элементов в биосфере // Экологическая химия 2009, 18(1): 6061.

54. Чернова О. В., Н. О. Ковалева. О работе научного семинара по теоретическим проблемам почвоведения в 2004-2006 гг. - Почвоведение. 2007. № 10. С. 12751280.

55. Шредингер Э. (SchrödingerE.) Что такое жизнь с точки зрения физики. М.: ИЛ, 1947.

56. Яблоков А.В., Остроумов С.А. Охрана живой природы: проблемы и перспективы. 1983. М.: Леспромиздат. 272 с.

57. Яблоков А.В., Остроумов С.А. Уровни охраны живой природы. М.: Наука, 1985. $176 \mathrm{c}$.

58. Goldsmith F. B. - The Journal of Ecology, 1992. Vol. 80, No. 1, p. 186-187;

59. Hartshorn G. S. A Russian "Silent Spring". - BioScience, 1992, Vol. 42, No. 7, p. 559560.

60. Kapitsa A.P. Formulation of fundamental principles for foundation of the theory of the apparatus of the biosphere. - Environment Ecology and Safety of Life Activity (Kiev). 2007. No. 1 (37). P. 68-71.

61. Kapitsa P.L. Review of the book: S.A. Ostroumov. Aquatic organisms in water selfpurification and biogenic migration of elements. Moscow. MAX Press. 2008. 200 p. Ecologica, 2009. V.16. No. 53.P.8.

62. Kolesov G.M. Determination of microelements: neutron activation analysis in geochemistry and cosmochemistry // J. Anal. Chem. 1994. V.49. No.1. P.50-58.

63. McCutcheon S.C., Schnoor J.L. (Eds) Phytoremediation. Wiley. Hoboken. 2003. 988 p. 
64. Ostroumov S.A. Inhibitory analysis of top-down control: new keys to studying eutrophication, algal blooms, and water self-purification. - Hydrobiologia. 2002. T. 469. № 1-3. C. 117-129.

65. Ostroumov S.A. Some aspects of water filtering activity of filter-feeders. Hydrobiologia. (2005) v.542. p. 275-286.

66. Ostroumov S.A. Biological Effects of Surfactants.CRC Press.Taylor \& Francis.Boca Raton, London, New York. 2006. 279 p. Subject Index: p.255-279. ISBN 0-8493-2526-9.

67. Ostroumov S.A., Dodson S., Hamilton D., Peterson S., Wetzel R.G. Medium-term and long-term priorities in ecological studies // Rivista di Biologia / Biology Forum. 2003. 96: 327-332. Abstracts in Eng. and Italian (p. 332). Bibliogr. 20 ref.

68. Yablokov A.V., Ostroumov S.A.Conservacion de la Naturaleza Viva. 1989. Moscu (Moscow).Vneshtorgizdat Press. Editorial Científico-Técnica.238 р. (на испанск. яз.).

69. Yablokov A.V., Ostroumov S.A.Conservation of Living Nature and Resources: Problems, Trends, and Prospects. Berlin, New York et al. Springer. 1991. 272 p. ISBN 3-540-52096-1; ISBN 0-387-52096-1.

70. Моисеенко, Т. И., Даувальтер, В. А., \& Родюшкин, И. В. (1997). Геохимическая миграция элементов в субарктическом водоеме (на примере озера Имандра). Апатиты: Изд-во КНЦ РАН.

71. Моисеенко, Т. И., Н. А. Гашкина. "Биоаккумуляция ртути в рыбах как индикатор уровня загрязнения вод." Геохимия 6 (2016): 495-504.

72. Моисеенко Т. И., Гашкина Н. А. Биогеохимия кадмия: антропогенное рассеивание, биоаккумуляция и экотоксичность //Геохимия. - 2018. - №. 8. - С. 759-773.

73. Моисеенко, Т. И. (2019). Биодоступность и экотоксичность металлов в водных системах: критические уровни загрязнения. Геохимия, 64(7), 675-688.

74. Ермаков, В. В., \& Ковальский, В. В. (1974). Биологическое значение селена. Москва : Наука, 1974. - 298 с.

75. Ермаков, В. В., Тютиков, С. Ф., Дегтярев, А. П., Данилова, В. Н., Гуляева, У. А., \& Догадкин, Д. Н. (2020). Формирование биогеохимических аномалий в бассейне р. Баксан. Геохимия, 65(10), 955-968.

76. Ермаков, В. В., Карпова, Е. А., Корж, В. Д., \& Остроумов, С. А. (2012). Инновационные аспекты биогеохимии. (Под ред.: Федонкин М.А., Остроумов С.А.); Москва, ГЕОХИ РАН, 2012. 345 с. ISBN: 978-5-905049-04-0; https://www.researchgate.net/publication/269093017 ;

77. Ермаков, В. В. (2015). Геохимическая экология и биогеохимические критерии оценки экологического состояния таксонов биосферы. Геохимия, (3), 203-221.

78. Остроумов, С. А., Данилова, В. Н., Хушвахтова, С. Д., Ермаков, В. В., Тютиков, С. Ф., Тропин, И. В., \& Котелевцев, С. В. (2016). Содержание химических элементов, глутатиона и металлотионеинов в элодее канадской (Elodea canadensis) в связи с экологическим мониторингом. Экологическая химия, 25(4), 197-203.

79. Данилова, В. Н., Хушвахтова, С. Д., Ермаков, В. В., \& Остроумов, С. А. (2018). Биогеохимические аспекты аккумулирования ртути в биосфере. In Труды Всероссийского ежегодного семинара по экспериментальной минералогии, петрологии и геохимии (рp. 394-396).

80. Остроумов С. А. Химико-биологические взаимодействия и новое в учении о биосфере В.И. Вернадского. Москва, МАКС-Пресс. 2013. 92 с.

81. Kothny E.L. Palladium in plant ash. // Plant and Soil. 1979. Vol.53. P.547-550.

82. Scandium. Chemical properties of scandium. Health effects of scandium. Environmental effects of scandium. http://www.lenntech.com/periodic/elements/sc.htm ; 
83. Ceccantini G., Figueiredo A.M.G., Sondag F., Soubies F. Rare earth elements and titanium in plants. soils and groundwaters in the alkaline-ultramafic complex of Salitre, MG, Brazil // Contaminated Soils. 3rd international Conference on the Biogeochemistry of Trace Elements. Paris (France). May 15-19, 1995; http://horizon.documentation.ird.fr/exl-doc/pleins_textes/pleins_textes_7/b_fdi_5152/010015618.pdf

84. Ferrand E., Benedetti M. F., Leclerc-Cessac E., and Dumat C. Study of the mechanisms involved in the rhizosphere for the absorption of zirconium by vegetables // Difpolmine Conference. 12-14 December 2006. Le Corum - Montpellier, France. http://www.ademe.r/difpolmine/Difpolmine_RapportFinal/communication/12_13_poster s-Corum/Difpolmine_Poster13_Dumat_proceeding.pdf;

85. Ferrand E., Benedetti M. F., Leclerc-Cessac E., and Dumat C. Study of the mechanisms involved in the rhizosphere for the absorption of zirconium by vegetables // Difpolmine Conference. 12-14 December 2006. Le Corum - Montpellier, France. http://www.ademe.r/difpolmine/Difpolmine_RapportFinal/communication/12_13_poster s-Corum/Difpolmine_Poster13_Dumat_proceeding.pdf ;

86. Остроумов С.А., Тодераш И.К., Зубкова Е.И., Котелевцев С.В., Ермаков В.В., Крупина М.В., Ене А., Микус А.А., Билецки Л.И., Бряхнэ А., Мирон А. Биогенная миграция меди в водных экосистемах // Известия Академии наук Молдовы. Науки о жизни [ Buletinul Academiei de stiinte a Moldovei. Life Sciences], № 3, c. 4-21.

87. Остроумов C.A., Колесов Г.М., Тодераш И.К., Ени А. Выявление элементов (La, $\mathrm{Au}, \mathrm{U}, \mathrm{Cs}, \mathrm{Ba}, \mathrm{Na}, \mathrm{Ce}, \mathrm{Se}, \mathrm{Sb}, \mathrm{Hf}, \mathrm{Th}, \mathrm{Sc}, \mathrm{Sm}$ и других) в биогенном детрите водных микрокосмов с Viviparus viviparus, Unio pictorum, Ceratophyllum demersum // Известия Академии наук Молдовы. Науки о жизни [ Buletinul Academiei de stiinte a Moldovei. Life Sciences], 2009. № 2 (308), c. 85-95.

88. Остроумов С.А., Колесов Г.М. Детектирование в компонентах экосистем золота, урана и других элементов методом нейтронно-активационного анализа // Экологические системы и приборы, [издательство Научтехлитиздат (М.)], 2009. № 10, c. 37-40.

89. Korobova E. M. Toxicity as a Biogeochemical Problem //Geochemistry International. 2020. - T. 58. - №. 10. - C. 1092-1096.

90. Korobova, E. M. (2017). Combined assessment of the ecological and geochemical state of anthropogenically impacted areas. Geochemistry International, 55(10), 861-871.

91. Korobova, E. M. (2017). Principles of spatial organization and evolution of the biosphere and the noosphere. Geochemistry International, 55(13), 1205-1282.

92. Korobova, E. M., Berezkin, V. U., Korsakova, N. V., Krigman, L. V., Romanov, S. L., \& Baranchukov, V. S. (2019). Iodine in Soils and Potatoes Produced in Private Farms of Bryansk and Gomel Regions Located in the Impact Zone of the Chernobyl Accident. Eurasian Soil Science, 52(10), 1266-1273.

93. Korobova, E., Romanov, S., \& Silenok, A. (2020). Endemic diseases of geochemical origin and methodological approaches toward their prevention and elimination. Environmental geochemistry and health, 42(8), 2595-2608.

94. Korobova, E. M., Beryozkin, V. U., Kolmykova, L. I., Korsakova, N. V., \& Krigman, L. V. (2016). Iodine deficiency in agricultural landscapes of the Bryansk region. RUDN Journal of Ecology and Life Safety, (3), 57-65.

95. Ермаков В. В., Моисеенко Т. И. Х Международная биогеохимическая школа //Вестник Тюменского государственного университета. Вестник Тюменского 
государственного университета. Экология и природопользование. 2017. Том 3. No. 2. C. 166-175. https://elib.utmn.ru/jspui/bitstream/ru-tsu/15256/1/166_175.pdf;

96. Ermakov, V., Bech, J., Gulyaeva, U., Tyutikov, S., Safonov, V., Danilova, V., \& Roca, N. (2020). Relationship of the mobile forms of calcium and strontium in soils with their accumulation in meadow plants in the area of Kashin-Beck endemia. Environmental Geochemistry and Health, 42(1), 159-171.

97. Ermakov, V. V., Gulyaeva, U. A., Tyutikov, S. F., Kuz'mina, T. G., \& Safonov, V. A. (2017). Biogeochemistry of calcium and strontium in the landscapes of eastern Transbaikalia. Geochemistry International, 55(12), 1105-1117.

98. Ermakov, V. V., Tyutikov, S. F., \& Danilova, V. N. (2020). Ecological Monitoring of the Unal Depression, Northern Ossetiya-Alania, Using Techniques of Biogeochemical Indication. Geochemistry International, 58(3), 332-341.

99. Ermakov, V. V., Tyutikov, S. F., Degtyarev, A. P., Safonov, V. A., Danilova, V. N., Khushvakhtova, S. D., ... \& Krechetova, E. V. (2018). Biogeochemical differentiation of living matter and biodiversity in the Ardon polymetallic subregion of the biosphere. Geochemistry International, 56(4), 318-331.

100. Ermakov, V. V., Tyutikov, S. F., Degtyarev, A. P., Danilova, V. N., Gulyaeva, U. A., \& Dogadkin, D. N. (2020). Formation of Biogeochemical Anomalies in the Baksan River Basin.

Geochemistry International, 58(10), 1097-1109. 


\title{
О СОВЕРШЕНСТВОВАНИИ МЕХАНИЗМА ПРИМЕНЕНИЯ АЛЬТЕРНАТИВНЫХ И ВОЗОБНОВЛЯЕМЫХ ИСТОЧНИКОВ ЭНЕРГИИ В АЗЕРБАЙДЖАНЕ
}

\author{
Арзу Миргейдарова
}

Азербайджанский государственный университет нефти и промышленности, канд. техн. наук, доцент кафедры «Экономика и менеджмент отраслей энергии и нефтехимии» Азербайджан.

E-mail: arzu.mirgeydarova@mail.ru

\begin{abstract}
This article presents of aspects of the introduction of alternative and renewable energy sourses in Azerbaijan.The prospect of introducting the countries unconventional reserves in the energy sector is considered. The necessary of an early transition to a new - non-carbon energy of the future, independent of the finite resources of nature, is indicated.
\end{abstract}

Keywords: traditional and non-traditional reserves, energy saving, alternative and renewable energy sources, prospects for the use of ARES.

\section{РЕЗЮМЕ}

В данной статье приведены аспекты внедрения альтернативных и возобновляемых источников энергии в Азербайджане. Рассмотрена перспектива внедрения нетрадиционных запасов страны в энергосекторе. Указана необходимость скорейшего перехода к новой - неуглеродной энергетики будущего, независимой от конечных ресурсов природы.

Ключевые слова : традиционные и нетрадиционные запасы, энергосбережения, альтернативные и возобновляемые источники энергии, перспективы применения АВИЭ.

Актуальность: Известно, что энергетика является одной из основ человеческой цивилизации, важнейшим фактором производства и жизнеобеспечения современного общества. Именно она ресурсно обеспечивает все силовые и температурные процессы производства, информационно-управленческую деятельность и социальную сферу, а также формирует значительные потоки мировой торговли и тематики международных политических отношений [1]. Проблема обеспечения электрической энергией многих отраслей мирового хозяйства, постоянно растущих потребностей более чем шестимиллиардного населения Земли становится сейчас все более насущной. Во все времена человечество, для обеспечения своей жизнедеятельности и удовлетворения своих различных жизненных потребностей, создавало, совершенствовало и развивало виды производства. Это и определило современное состояние энергетики, которая сейчас переживает сложный период развития и ожидания неизбежных количественных и качественных перемен. Всемирно общепризнано, что основным фактором, определяющим развитие материальной культуры людей, является создание и использование различных источников земли. Поэтому, уровень развития энергетики, является прямым показателем экономического развития страны. Актуальность обьекта исследования определяется 
стремительным исчерпанием традиционных энергетических ресурсов и постоянно растущей ценой на их использование на фоне возрастающих потребностей в электроэнергии, обусловленных развитием экономики и эволюцией образа жизни людей.

Введение: Использовать альтернативные и возобновляемые источники энергии (АВИЭ) человечество стало раньше, чем научилось добывать уголь, нефть и газ. Однако со временем потребление энергии росло - и человеку индустриального общества требовалось уже в 100 раз больше энергии, чем в первобытную эпоху. И тогда обеспечить стабильную поставку таких мощностей стало возможным благодаря сжиганию ископаемого топлива. Потребляя огромное количество традиционных запасов энергии -ископаемого топлива, такого как нефть, газ, торф, уголь, люди стали перед угрозой его исчезновения. И к тому же, сжигая огромное количество топлива и выбрасывая тем самым в атмосферу колоссальное количество углекислого газа, они столкнулись с проблемой глобального потепления - так называемого «парникового эффекта» в планете. Поэтому, человечество снова задумалось об использовании альтернативных и возобновляемых источников энергии, так как запасы нефти, газа, торфа исчерпаемы, а их использование наносит большой вред окружающей среде. Немаловажную роль в использовании АВИЭ играет политическая и экономическая нестабильность в странах, специализирующихся на добыче ископаемых источников энергии, так как их добыча не может возрастать до бесконечности в силу ограниченности природных запасов.

В последнее время мировое энергохозяйство сталкивается ныне с серьезными вызовами и рисками, которые все более ставят под сомнение его способность и далее обеспечивать основные требования устойчивого энергоснабжения - достаточность, доступность, приемлемость, эффективность и экологичность. Есть все основания говорить о закономерном вызревании в современном мире глобального энергетического кризиса, который, в отличие от прошлого, носит уже не преходящий характер, а является долгосрочным, структурным, а в текущем плане - осложняющим нынешний финасовоэкономический кризис. Истоки этой энергетической проблемы уходят, прежде всего, в ограниченность запасов в мире традиционного углеводородного топлива. Поэтому, на сегодняшний день главной задачей является поиск, разработка и внедрение новых, альтернативных, возобновляемых, не загрязняющих окружающую среду и неиссякаемых источников энергии.

Перспективы применения АВИЭ в стране. Как известно, получение, обмен и консервация энергии состоит из фундаментальных процессов, изучаемых физической наукой, основной закономерностью которой является закон сохранения энергии [2]. Исходя из вышеуказанного закона, в Земле предвидется глобальный кризис в процессе получения энергии. В настоящее время энергетические потребности людей обеспечиваются за счет 3-х основных видов энергоресурсов: традиционного топлива, воды и продукты расшипления атомного ядра. По подсчетам специалистов, при современных обьемах энергопотребления запасов топлива на планете хватит на 150-180 лет, а в частности- нефти - на 30-35 лет, природного газа - 50-60 лет, угля и торфа - на 400-425 лет [3]. Возникает исторический вопрос- как быть?

В перспективе специалисты видят выход только в создании на смену нынешней традиционной углеводородной энергетике, новой- неуглеродной энергетики будущего, независимой от конечных ресурсов природы. Постоянная угроза возникновения кризиса с поставками нефти в мире, а также риски, связанные с развитием ядерной энергетики и 
озабоченность современного общества проблемами окружающей среды и, соответственно, климатическими вопросами, обусловили возникновение современной энергетической политики, которая нацелена на то, чтобы в течение нескольких следующих десятилетий была сформирована возобновляемая энергетическая система, базирующаяся на альтернативных и возобновляемых источниках энергии, без выбросов парниковых газов в атмосферу. Причина поиска таких источников энергии потребность получать её из энергии возобновляемых или практически неисчерпаемых природных ресурсов и явлений. Во внимание может браться также экологичность и экономичность, низкая стоимость эксплуатации и ожидаемый топливный дефицит в традиционной энергетике.

В настоящее время для государств всего мира важнейшем фактором определяющим статус и уровень их развития, является обеспечение энергией и электричеством своего населения и промышленности. Государства всех странах мира в связи с непрерывным развитием их народного хозяйства вынуждены независимо от существующего в стране уровня развития экономики и технологии всё большее внимание обращать на обеспечение промышленных предприятий и предприятий жилищно-коммунального хозяйства достаточным количеством электроэнергии. Однако в связи с приближающимся в мире дефицитом ископаемых источников энергии (нефти, газ, угля и др.) ученые промышленно развитых стран стремятся найти более эффективные методы получения электричества на основе альтернативных источников энергии. К основным видам АВИЭ сегодня относят виды энергии, полученные из воды (гидроэнергетику), ветра (ветроэнергетику) и солнца (гелиоэнергетику). В некоторых местах можно развивать энергетику прилива и отлива морей, океанов(волновую), тепловую энергию земных недр (геотермальную) и энергетику, полученную из биомасс. Энергия, образующаяся от этих источников, бесконечна и поэтому ей находят все большее применение в технических аспектах деятельности человека. Следует отметить, что возобновляемая энергия не нарушает законов физики о возникновении энергии - просто она постоянно пополняется самими же источниками.

На данный момент использование АВИЭ активно развивается в Европе, где страны вынуждены закупать топливо для работы традиционных электростанций. Но, по мнению некоторых экспертов, в развитии альтернативной энергетики заинтересованы и государства, чья экономика в какой-то степени зависит от экспорта нефти и газа (например, такие страны как Азербайджан и Казахстан). Ведь если в этих регионах использовать АВИЭ вместо газа, это топливное сырье можно будет отправить на экспорт.

В связи с этим, современные передовые компании мира все больше обращают свой взор на альтернативные и возобновляемые источники энергии. Постоянно ведутся разработки в этом направлении, и, в скором времени, использование технологий, работающих на подобных источниках, станет не просто популярным, но и обыденным в нашей жизни - ведь человечество само должно защитить себя от экологических катастроф, которые можно избежать только при бережном обращении с природными peсурсами. Согласно данным компании British Petroleum, в 2018 году доля АВИЭ составила 10,4 \% в мировой генерации электричества, впервые обойдя атомную энергию по этому показателю [4]. В первичной энергии (общем энергобалансе) доля альтернативной энергетики выросла до 5\%, поднявшись с 4,5\% в 2018 году и также обойдя атомную энергию. По оценкам Европейской комиссии, к концу 2020 года в 
странах Евросоюза, в индустрии возобновляемой энергетики будет создано 2,8 миллионов рабочих мест, что составляет $1,1 \%$ от всеобщей валовой продукции (ВВП) [5]. По данным аналитической компании ENERDATA, в Норвегии уже сейчас около 97\% электроэнергии добывается из альтернативных и возобновляемых источников с учетом гидроэнергетики, около 80\% - в Новой Зеландии и Бразилии. В Европе 30-40\% энергии АВИЭ вырабатывается в Германии, Италии, Испании и Великобритании. В России этот показатель составляет 17,2\%, из них доля СЭС и ВЭС - менее 1\% [6].

Следует отметить, что недры Азербайджана богаты энергоресурсами. Перспективы использования энергии вод, тепла, солнца, ветра, биомассы поистине безграничны. Основная задача, стоящая перед экономикой Азербайджанской Республики - правильно оценить и рационально использовать потенциал возобновляемых ресурсов, найти их место применения в топливно-энергетическом комплексе. Решение этой дилеммы позволит снизить зависимость экономики республики от углеводородных энергетических ресурсов и будет способствовать ее стабильности и развитию. Факт что ресурсы нетрадиционных источников энергии (т.е. АВИЭ) почти неисчерпаемы, и в Азербайджане они на уровне выше среднемировых. По темпам экономического роста Азербайджан, являющийся одной из ведущих стран мира , может стать примером для многих мировых нефтедобывающих стран, если активно начнет использовать ресурсы солнца, ветра, моря, рек, геотермальных источников, и с помощью возрастающего потенциала, постепенно начать диверсификацию своей энергетики. Возобновляемые источники энергии могут внести весомый вклад в энергетический баланс Республики.

Следует отметить, что переход к устойчивому развитию невозможен без внедрения новых инновационных технологий , возобновляемой энергетики и энергосбережения. На росте потребления энергии в последние годы сказывается, и появление новых масштабных претендентов на нее в лице стран «догоняющего развития» (например, КНР, Индия, Бразилия, Южная Корея, Малайзия и др.). Ожидается, что на долю развивающихся стран до 2030 г. придется 88\% прироста спроса на нефть и $2 / 3$ ее мирового потребления, что обещает сделать конкуренцию на мировом энерго рынке неизмеримо более жесткой. Специалисты говорят в этой связи даже о возможном росте мирового энергопотребления по математической экспоненте, тем более что научно-технический прогресс, существенно нивелировавший в XX веке негативное воздействие фактора ограниченных ресурсов, в настоящее время явно не справляется с этой управляющей ролью.

Так как энергетика - традиционно один из важнейших секторов экономики Азербайджана, в 2020 году эту отрасль ждут очень большие перемены: страна активно и интенсивно развивает такую новую и крайне перспективную отрасль, как альтернативная энергетика. Развитию этой отрасли государство уделяет серьезное внимание, а иностранные инвесторы готовы сегодня вложить в азербайджанскую экономику сотни миллионов долларов. Если несколько лет назад специалисты дискутировали по поводу того, настолько ли необходимо вкладывать огромные средства в развитие отрасли, которая сейчас "как бы не нужна", то сегодня важность возобновляемых источников энергии общеизвестна. И Азербайджан, несмотря на большие запасы нефти и газа, вкладывается в развитие альтернативной энергетики, делая ставку не только на традиционные источники, но и на развитие передовых направлений. Компании ACWA Power (Королевство Саудовская Аравия) и MASDAR (Объединенных Арабских Эмиратов) уже подписали в Баку Исполнительный договор, касающийся строительства ветряных и солнечных электростанций в нашей стране. На сегодняшний день доля возобновляемых источников энергии, включая гидроэнергетические ресурсы, в 
общем объеме потребления энергии в Азербайджане достигла 18\%. Это, конечно, хороший результат, но он совершенно не отражает огромный потенциал, имеющийся в стране. Правительство намерено нарастить удельный вес возобновляемой энергетики к 2030 году до 30\%. Выполнить эту амбициозную задачу помогут и значительные инвестиции из арабских стран, и передовые европейские технологии. Возможности Азербайджана в области альтернативной энергетики очень велики, и уж точно потенциал страны - самый высокий в Кавказском регионе. Большая часть суммарного потенциала альтернативных и возобновляемых источников энергии в Азербайджане приходится на солнечную энергию - 5 тысяч мегаватт. На втором месте идет энергия ветра - 4500 мегаватт, а оставшаяся часть приходится на биомассу (1500 мегаватт), геотермальную энергию (800 мегаватт) и потенциал малых и средних рек (350 мегаватт) [7].

Несомненно, Азербайджан скоро достигнет значительного результата в развитии альтернативной энергетики. Потенциал возобновляемых источников энергии в Азербайджане составляет свыше 25,3 тысячи мегаватт, что позволяет вырабатывать 62,8 миллиарда киловатт-часов электроэнергии в год. Такая необходимость развития альтернативной энергетики продиктована не модным трендом, а требованием обеспечить устойчивое развитие и энергетической сферы и экономики Азербайджана в целом. Развивая альтернативную энергетику, в будущем страна параллельно достигнет целого ряда целей: получится, в том числе, снизить зависимость от традиционных энергоресурсов, еще более укрепить прочность всей энергосистемы и, конечно, положительно повлиять на экологическую обстановку.

Необходимо отметить, что в 2019 году Азербайджан занял 44-ю позицию в индексной таблице отчета Давосского всемирного экономического форума мирового форума по новому индексу энергетического перехода (ЕTI), продемонстрировав второй высокий показатель на пространстве СНГ. Отчет учитывает основные критерии создания безопасных, устойчивых, доступных и инклюзивных энергосистем для будущих поколений и предусматривает переход на возобновляемые и альтернативные энергосистемы.

Сегодня для Азербайджана наиболее актуальны технологии по использованию огромных ресурсов ветряной и солнечной энергии. Причем эти технологии могут использоваться повсеместно как на уровне государства и крупных энергетических компаний (производство электроэнергии для промышленности, сельского хозяйства, коммунальной сферы, а также бытового потребления), так и на уровне отдельных семейных хозяйств, особенно в небольших городах и в сельской местности.

Действительно, первоначальные инвестиции в разработку и внедрение технологий альтернативной энергетики в стране велики, но они окупаются в приемлемые сроки (как правило, за 7-10 лет) и позволяют сохранить в неприкосновенности уникальную природу Азербайджана, а также здоровье его граждан. Исходя из вышеизложенного, становится понятным - для чего вообще нужно применение АВИЭ?

Необходимо отметить, что мы даже несколько запаздали с переходом на передовую экологически чистую - так называемую «зеленую» энергию (Green energy) будущего. В развитых странах мира ее доля в общем обьеме выработки электроэнергии уже сегодня составляет десятки процентов, зачастую, превышая 50 \%. В целом , доля альтернативных и возобновляемых источников энергии в мировом производстве электроэнергии составляет $26 \%$, а Азербайджан довольствуется лишь 17 \%. Однако это вовсе не означает, что «отставание» неопределимо- в Республике отличные перспективы для развития АВИЭ. По экономическим и энергетическим расчетам, при реализации задуманного, уже 
в 2050 году наш показатель в этой сфере сравняется с мировым и достигнет до 85 \%. А по более краткосрочным подсчетам, уже в 2030 году наша страна почти вдвое увеличит долю АВИЭ и доведет ее до $30 \%$.

Заключение: Так что медлить с внедрением АВИЭ в Азербайджане (и во всем мире) нельзя, иначе человечество скоро может столкнуться с еще большими изменениями климата, в частности, повсеместным повышением температуры окружающей среды со всеми вытекающими отсюда последствиями. Вместе с тем, для уменьшения негативного влияния на экологию антропогенных факторов, внедрение АВИЭ должно идти параллельно с технологическим переоснащением традиционных систем выработки энергии. Этой проблемой сегодня озабочена научная общественность всего мира. И альтернативная и возобновляемая энергия, думается, что сможет внести свою большую лепту в ее решение в глобальном (мировом) и локальном (в отдельно взятой стране) масштабах.

\section{ЛИТЕРАТУРА}

1. М.Ф. Джалилов Альтернативные регенеративные энергетические системы (учебник для ВУЗ-ов )/ (на.азерб. яз.), Баку, НПЦ «Техсил», 2009, 406 с.

2. Агеев В.А. Нетрадиционные и возобновляемые источники энергии /ГОУВПО «Мордовский государственный университет» им. Н.П.Огарева. Институт энергетики. Кафедра теплоэнергетических систем. Саранск, 2004, 158c.

3. Алиев Т.Н., Наджафов 3.М., Бабаев М.Т. Организация управления потенциалом. Баку, изд-во «Эльм», 2006, 126 с.

4. BP Statistical Review of World Energy for 2018 year, UK, London, 2018.

5. The Republic of Azerbaijan's Fifth National Report to the Convention on Ecological and Biological Diversity, April, Baku, Azerbaijan, 2014.

6. Azerbaijan: Alternative and Renewable Energy-A Business Perspective, Caspian İnformation Centre, Baku, Azerbaijan, 2013.

7. Http://www.azstat.org/

\section{ON THE ISSUE OF INTRODUCTION OF ALTERNATIVE AND RENEWABLE EMNERGY SOURCES IN AZERBAIJAN}

\section{Arzu Mirqeydarova}

Azerbaijan State Oil and Industry University, Azerbaijan.

\section{ABSTRACT}

This article presents of aspects of the introduction of alternative and renewable energy sourses in Azerbaijan.The prospect of introducting the countries unconventional reserves in the energy sector is considered. The necessary of an early transition to a new - non-carbon energy of the future, independent of the finite resources of nature, is indicated.

Keywords: traditional and non-traditional reserves, energy saving, alternative and renewable energy sources, prospects for the use of ARES. 


\title{
СТРАТЕГИЧЕСКОЕ УПРАВЛЕНИЕ БРЕНДОМ В ГЛОБАЛЬНОЙ СРЕДЕ
}

\author{
Халиг Гурбанов \\ Азербайджанский Государственный Университет Нефти и Промышленности, Главный предподаватель \\ кафедра «Экономики и менеджмента энергетики и нефтехимии», Email: ibrahimovasadagat06@gmail.com
}

\begin{abstract}
In modern business conditions, the brand is essentially important for business strategy success. Customers increasingly purchase products on the basis of brand, reputation, and other immaterial attributes and less on the basis of their physical characteristics. A strong brand increases the level of customer satisfaction and loyalty, and efficiency of business strategy. Brand with great value in the market is an important asset of firm. In the paper, authors analyze the importance of strategic brand management in the conditions of global environment.
\end{abstract}

Keywords: brand, customer, equity, strategy, management, efficiency

\section{РЕЗЮМЕ}

В современных условиях ведения бизнеса бренд играет важную роль в успехе бизнесстратегии. Клиенты все чаще покупают товары на основе бренда, репутации и других нематериальных атрибутов и в меньшей степени на основе их физических характеристик. Сильный бренд повышает уровень удовлетворенности и лояльности клиентов, а также эффективность бизнес-стратегии. Бренд, имеющий большую ценность на рынке, является важным активом фирмы. В статье автор анализируют важность стратегического управления брендом в условиях глобальной среды.

Ключевые слова: бренд, клиент, капитал, стратегия, управление, эффективность.

Фактические быстрые изменения в окружающей среде требуют определенных изменений в деловой активности, которые включают корректировку философии бизнеса и ориентации предприятия, а также изменения бизнес-портфеля, организационной структуры и подхода к управлению. Предприятие должно адаптировать свою коммерческую деятельность к нуждам и требованиям окружающей среды, что стало императивом его существования, роста и развития. Также необходимы радикальные (трансформационные) повороты, требующие изменения основных ценностей компании. Рациональная реакция способствует сохранению основ конкурентного преимущества и созданию источников для достижения нового. Рынок стал глобальным, а региональные и другие интеграции способствовали развитию рынков с неустойчивыми границами. Развитие технологий позволяет устанавливать связи в невероятных масштабах. Создание рынков без границ, массовое удовлетворение потребностей стратегически важных клиентов, развитие и управление отношениями, сосредоточение внимания на предоставлении высших ценностей и сетевых организаций стали ключевыми факторами успеха в бизнесе. Это также факторы изменения бизнес-среды, что требует адаптации стратегических ответных действий предприятий. 
Управление предприятием в мировой экономике на основе знаний стало более сложным и требует пересмотра бизнес-моделей и всех сегментов управления. Один из сегментов - бренд-менеджмент. Тот факт, что ничто на рынке не приобретается определенно, поскольку конкуренция интенсивная, а клиенты требовательны, увеличивает роль бренда и его анализа в теории и практике маркетинга.

Бренд - это нематериальный актив предприятия, имеющий большую ценность. Поддержание и увеличение капитала, полученного из активов, требует адекватной реакции руководства предприятия, которая существенно отличается от управления брендом в конце прошлого века. Безусловно, успешные предприятия стараются сделать свои бренды более известными, что создает основу для их роста и развития.

Изменения в окружающей среде, вызванные глобализацией, обострением конкуренции, изменением поведения потребителей и т.д., предьявляют новые требования к менеджменту в смысле его адекватной стратегической реакции. Это вызов для всех предприятий, независимо от уровня глобализации. Безусловно, способ стратегического управления брендом в конкретном предприятии, помимо всего прочего, будет зависеть от структуры, стоимости и положения бренда на выбранных целевых рынках (глобальном, региональном, локальном; сильном, слабом; корпоративном, знакомом, индивидуальный и др.). Каждая категория требует определенного подхода к управлению. Однако общим для всех компаний, других организаций и учреждений является то, что стратегическое управление брендом более эффективно, когда оно использует сбалансированный подход, включая оптимизацию управления брендом и отношений с клиентами, поскольку сила бренда в большей степени обусловлена лояльностью клиентов, и стоимость его жизни.

Для управления брендом на глобальном рынке очень важно понимать изменения в поведении клиентов и их готовность принимать глобальные бренды. Они важны не только для глобальных компаний в их попытках изменить предпочтения клиентов в пользу своих глобальных брендов. Мировые бренды взаимно конкурируют (марки автомобилей, бренды мобильных телефонов и т. д.), но они также борются против региональных и местных брендов. С другой стороны, предприятия, работающие как национальные или международные и не принадлежащие к группе глобальных, пытаются укрепить свои бренды, используя преимущества на местных рынках и возможности для удовлетворения потребностей клиентов без глобальной ориентации. В этом процессе все предприятия сталкиваются с многочисленными проблемами и угрозами, поскольку поведение клиентов постоянно меняется. Исследования показывают, что примерно 55\% покупателей предпочитают мировые бренды, считая их более качественными и сильными, и что предприятия проявляют к ним большую социальную ответственность. Значительное количество опрошенных клиентов - $23 \%$ - принимает «миф о глобализации» и составляет группу «глобальных мечтателей». С точки зрения бренд-менеджмента, важным является то, что примерно 13\% покупателей против глобализации, избегают глобальных брендов и по возможности выбирают локальные. Также важна группа глобальных агностиков (8\%). Они покупают не только в соответствии с информацией о глобальном бренде, но всегда сравнивают стоимость различных брендов, используя набор критериев, и при принятии окончательного решения выбирают бренд с большей долей капитала, независимо от того, является ли он глобальным или локальным. Эти и другие результаты исследований 
указывают на необходимость стратегического управления брендом для достижения успеха.

Изменение роли бренда в создании ценности для клиентов способствует новой интерпретации важности бренда. Основное внимание уделяется пониманию взаимодействия продукта и бренда, где бренд не является дополнением к продукту, а физический продукт является элементом бренда. Бренд - это сочетание атрибутов, обещанных предприятием, преимуществ, которые оно дает клиентам, и ценностей, которых они ожидают. Подчеркивая важность переменных доверия, преданности и лояльности между клиентами и предприятием, обращает внимание на отношения между клиентом и брендом. Удержание клиентов и их связь с брендом и предприятием требует налаживания разумного диалога с клиентами. Важность бренда в бизнес-стратегии подтверждает парадигма расчета его экономической ценности, называемая капиталом бренда. Бренд - это своего рода долгосрочная инвестиция, которая при грамотном управлении стала фактором прибыльности предприятия.

Бренд имеет существенное значение для успеха предприятия, учитывая, что в современных условиях ведения бизнеса труднее добиться желаемых бизнес-результатов без бренда. Процесс брендинга стал более важным и провокационным, чем когда-либо прежде, а товаров без бренда на рынке меньше. По оценкам, средний покупатель в США ежедневно знакомится с примерно 1500 различными брендами. Уменьшение бренда было инструментом защиты клиентов от неправильных покупок, и оно в большей степени синтезировало воспринимаемые качественные характеристики продукта, эмоциональные аспекты и репутацию. Успешный бренд становится символом, который выполняет некоторые важные функции для клиентов и увеличивает ценность продукта в их глазах. Бренд идентифицирует источник или производителя продукта и позволяет покупателям возложить ответственность на конкретного производителя или дистрибьютора. Это также позволяет клиентам снизить затраты на поиск продуктов. На основе того, что они уже знают о бренде - его качества, характеристик продукта и т.д. - покупатели могут делать предположения и формировать разумные ожидания относительно того, чего они могут не знать о бренде. В той мере, в какой клиенты осознают преимущества и выгоды от покупки бренда, они, вероятно, будут продолжать его покупать. Бренд обеспечивает покупателям стабильное и сопоставимое качество, независимо от места покупки, и может предложить дополнительное психологическое удовлетворение, учитывая связь между статусом и брендом.

C точки зрения предприятия (производителя, продавца) брендинг помогает дифференцировать продукт и создавать хороший имидж, который можно использовать для создания корпоративного имиджа. Продвижение брендовой продукции приводит к увеличению выборочного спроса, что помогает предприятию увеличивать свою долю рынка. Бренд также может стимулировать повторные покупки и повысить лояльность клиентов, что приведет к снижению эластичности цены. Успешный бренд позволяет расширить бренд за счет других продуктов и создать престиж, а также юридически защитить уникальные характеристики продукта.

В динамичной среде крайне важно создать сильный бренд, основанный на лояльности к бренду, его узнаваемости и имидже, воспринимаемом качестве, ассоциациях с брендом и других проприетарных активах, таких как патенты, товарные знаки и взаимоотношения с каналами сбыта. Эти активы предоставляют различные преимущества и ценность, что 
приводит к сильному расширению бренда и правильным навыкам и оригинальности его создателей.

Бренд - это когнитивная конструкция, которая, согласно концепции так называемой сущности Боромео, объединяет три компонента: реальность, символизм и воображение.

Процесс стратегического управления брендом важен для создания и поддержания капитала бренда. Разработка стратегии, которая успешно поддерживает или улучшает узнаваемость бренда, укрепляет ассоциации с брендом, подчеркивает качество бренда и его использование, является частью управления брендом. Стратегия бренда означает постоянные инвестиции в исследования и разработки, рекламу и обслуживание клиентов. Также важны мероприятия по измерению и контролю воздействия бренда.

Процесс стратегического управления брендом начинается с четкого понимания того, что бренд должен представлять и как его следует позиционировать по отношению к конкурирующим брендам. Цель состоит в том, чтобы определить и установить позиционирование бренда, которое будет отражать выгоды, которые предприятие может получить в максимальной степени. Это включает установление сущности бренда как набора воображаемых ассоциаций (атрибутов и преимуществ), которые являются характеристиками бренда, и выбор способа его представления. Речь идет об определении «сердца» и «души» бренда.

Лишь несколько предприятий применяют формализованную методологию, которая помогает им найти способ сократить свои усилия и повысить эффективность управления брендом. Стратегическое управление брендом будет более успешным, если оно основано на планировании портфеля брендов. Портфель брендов предприятия в партнерских отношениях часто состоит из брендов нескольких предприятий. Некоторые авторы разработали модель под названием «молекула бренда», в которой каждый бренд описывается как атом, а его размер указывает на роль бренда. Самый большой атом указывает на ведущий бренд, атом среднего размера указывает на стратегический бренд, а самый маленький атом указывает на поддерживаемые бренды. Обзор соответствующей литературы показывает, что существуют разные подходы, но большинство авторов считают, что необходимо принять несколько ключевых решений: создавать или нет бренд, выбирать название бренда (отдельные имена, названия для семейства продуктов, разные фамилии для разных продуктов. , сочетание корпоративного названия продукта и отдельных названий продуктов), определение стратегии брендинга (расширение линейки, расширение брендов, новые бренды, больше брендов, совместные бренды); изменение положения.

Отправной точкой в стратегическом анализе для принятия решений является иерархия брендов. Иерархия брендов основана на предположении, что продукт можно брендировать по-разному, в зависимости от того, сколько новых и существующих элементов бренда используется и как они сочетаются для любого продукта. Поскольку определенные элементы бренда используются для создания нескольких брендов, иерархия может быть построена так, чтобы представлять, как продукты вложены в другие продукты из-за их общих элементов бренда. Келлер выделил четыре потенциальных уровня иерархии. Самый высокий уровень иерархии - это бренд компании (или компании). Семейный бренд - это следующий более низкий уровень, и он определяется как бренд, который используется более чем в одной категории продуктов, но не обязательно является названием компании. Третий уровень - индивидуальный бренд. Это бренд, который был ограничен по существу одной категорией продуктов, хотя он может 
использоваться для нескольких различных типов продуктов в пределах категории. Последний уровень - это так называемый модификатор, который представляет собой средство для обозначения определенного элемента или типа модели или конкретной версии конфигурации продуктов.

Планирование портфеля брендов предлагается как инструмент для более эффективного принятия решений в процессе управления брендом. Поскольку портфель брендов - это набор всех брендов и линий брендов, которые предприятие предлагает клиентам в определенной категории, планирование портфеля брендов представляет собой процесс, который включает следующие этапы: определение брендов в портфеле брендов, оценка вклада каждого бренда эффективности бизнеса, оценка положения бренда (фактического и будущего), дифференциация брендов в портфеле, рассмотрение их возможностей и способностей предприятия по их использованию, повторное исследование портфеля и разработка стратегии реконструкции бренда.

Успешное позиционирование бренда - сложная задача. Многие бренды спотыкаются быстрее, чем им нужно. Чтобы этого избежать, необходимо: четко определить позиционирование бренда, прежде чем создавать узнаваемость в сознании клиентов, продвигать те атрибуты бренда, которые важны с точки зрения клиентов, вкладывать достаточно средств в разницу, которую имеют конкуренты легко копировать, чтобы отвечать на действия конкурентов в соответствии с потребностями клиентов и возможностями предприятия. Иногда проблемы могут быть вызваны решением компаний репозиционировать свои бренды, даже если это не оправдано.

Бренды создаются для удовлетворения потребностей клиентов и одновременно для достижения целей предприятия. Теоретики и практики маркетинга уделяют больше внимания созданию сбалансированного портфеля брендов для определенного сегмента как основы успешного стратегического управления. Компании с эффективным управлением портфелем брендов используют разные критерии для его оценки. Известные и проверенные методы оценки рыночной привлекательности предоставляют актуальную информацию для принятия решений брендами о конкуренции в выбранных целевых сегментах. Пересечение критерия рыночной доли в каждом сегменте и темпов развития отдельных отраслей, что является потенциалом для роста сегмента, позволяет оценить как текущую, так и будущую позицию бренда. В наши дни капитал бренда стал более важным, а также определенные инвестиции, необходимые для его поддержания или расширения, в зависимости от ценности жизни клиента. Практически это означает, что благодаря установлению долгосрочных отношений с клиентами фокус смещается в сторону знакомых или корпоративных брендов. Бренд-менеджмент успешен, если он обеспечивает рост клиентского капитала и когда имидж используется как для привлечения клиентов, так и для их удержания. Но это не значит, что бренд не важен. Напротив, для руководства очень важно сосредоточиться на увеличении капитала бренда, но этот процесс одновременно способствует увеличению капитала бренда и капитала клиентов. Сосредоточение внимания на эффективном управлении брендом посредством увеличения клиентского капитала в долгосрочной перспективе - эффективное стратегическое решение. Эффективное управление взаимоотношениями с клиентами означает, что предприятия могут также представлять новые бренды, которые предпочитают клиенты, и это способ связать клиентов с брендами предприятия, а не только с отдельным брендом. Как говорят некоторые авторы, бренды появляются и исчезают, а покупатели остаются. 
Клиентский капитал мог расти по-разному. Однако практика успешных предприятий показывает, что процесс роста клиентского капитала будет более эффективным и действенным, если будут выполнены определенные предположения. На основе исследований ведущих предприятий сделаны полезные выводы и рекомендации, которые могут быть использованы другими предприятиями. Рекомендации следующие:

- Решения по управлению взаимоотношениями с клиентами являются первичными, а решения по бренду - вторичными. Это требует координации в процессе управления клиентами и бренд-менеджмента, а также необходимости совместной работы менеджеров-специалистов;

- Расширение и развитие бренда зависят от клиентов;

- Клиент находится в центре внимания, и он является основой управления брендом, а подход к небольшим сегментам может повысить эффективность;

- План расширения бренда основан на потребностях клиентов и обеспечивает эффективное распределение маркетинговых ресурсов;

- Использование ресурсов в процессе управления брендом будет более эффективным, если клиенты находятся в «глубоких» отношениях с другими брендами предприятия;

- Сохранение бренда зависит от клиентов. Предлагается сохранить те бренды, у которых есть лояльные и прибыльные клиенты;

- Необходимо изменить подход к оценке капитала бренда. Исходное предположение в процессе оценки - понять драйвер капитала клиентов, а также влияние капитала бренда на клиентов и процесс покупки.

Модель капитала бренда, ориентированного на клиента (Customer-based brand equity $(\mathrm{CBBE}))$, дает уникальную точку зрения на то, что такое капитал бренда, как его следует создавать, измерять и управлять. Основная предпосылка модели СВВЕ заключается в том, что сила бренда заключается в том, что клиенты узнали, почувствовали, увидели и услышали о бренде в результате своего опыта с течением времени. Понимание потребностей и желаний клиентов и разработка продуктов для их удовлетворения имеют решающее значение для создания капитала бренда. Считается, что бренд имеет положительный капитал бренда, основанный на потребителях, когда клиенты более благосклонно относятся к продукту и способу его продвижения на рынке, когда бренд идентифицируется, чем когда это не так, что может привести к тому, что клиенты будут более склонны принимать новое расширение бренда , менее чувствительны к росту цен и прекращению рекламной поддержки.

Согласно модели СВВЕ, капитал бренда является «стратегическим мостом» из прошлого в будущее. Инвестиции в бренд следует рассматривать не как расходы, а как долгосрочные инвестиции, и качество инвестиций в создание бренда является наиболее важным фактором, а не обязательно количество инвестиций.

Процесс разработки и реализации программы маркетинга бренда включает выбор элементов бренда, интеграцию рыночных действий бренда и поиск ассоциаций брендов, которые косвенно будут использоваться для позиционирования бренда. Элементы бренда - это визуальные или словесные атрибуты, которые служат для идентификации и дифференциации продукта: название бренда, логотип, символы, символы, упаковка и слоганы. Их можно выбрать, чтобы повысить узнаваемость бренда или способствовать формированию сильных, благоприятных и уникальных ассоциаций с брендом. Вторичные ассоциации брендов могут быть связаны с репутацией компании, страной происхождения, 
имиджем места, лицензированием, различными культурными и спортивными мероприятиями.

Причин усиления бренда, обуславливающих стратегический подход к управлению, много. Например, конкурентное преимущество предприятия зависит от его репутации и силы бренда. Аакер цитирует следующие утверждения:

- Предприятия разные, не обращая внимания на большее сходство в их продуктах и услугах. Корпоративный бренд может иметь программу, которая способствует укреплению брендов определенных продуктов,

- Ассоциация брендов (включая все другие бренды предприятий) способствует укреплению доверия,

- Укрепление бренда охватывает все продукты и рынки и делает процесс управления брендом более простым и эффективным,

- Значение Interbrand для сотрудников должно подкрепляться миссией, целями, ценностями и культурой предприятия. Корпоративный бренд часто дает послание для отношений с клиентами, которое сильно отличается от бренда продукта.

- Бренд дает особую синергию.

Стратегические решения направлены на создание реальной лояльности к бренду. Исследования показывают, что можно выделить несколько категорий лояльности к бренду: (центральный бренд - это бренд особой важности), реальная лояльность к нескольким брендам, включая основной бренд, несправедливые повторные покупки с основным брендом и случайные покупки со стороны как лояльных, так и несправедливых клиентов других брендов.

Для создания реальной лояльности необходимо удовлетворять следующим критериям:

1) покупатели воспринимают основной бренд как более высокий по сравнению с предпочтительными конкурирующими брендами,

2) уровень потребительской склонности к ключевому бренду должен быть выше, чем склонность к другим брендам,

3) покупатель намеревается купить основной бренд, когда у него возникнет необходимость в покупке. Эффективная стратегическая реакция направлена на удержание текущих клиентов и создание препятствий для изменения бренда за счет повышения их удовлетворенности и лояльности. Управление качеством, удовлетворенностью, лояльностью и прибыльностью как стратегические инструменты способствует укреплению капитала бренда и повышению эффективности бизнеса.

Повышение лояльности к бренду - ключевая задача менеджеров по маркетингу. Понимание того, как клиенты оценивают и покупают бренд, имеет решающее значение не только для успеха маркетинга, но и для успеха бизнес-стратегии. Многие индикаторы показывают, что лояльность к конкретному бренду снижается в большом количестве товарных категорий. Помимо создания лояльности, важно повысить уровень использования определенных продуктов на разных рынках и от разных клиентов. Привлечение и удержание клиентов, лояльных к определенному бренду, наиболее полезно, когда они вместе являются крупными пользователями продукции. В зависимости от уровня лояльности к бренду можно сформулировать самые разные стратегии:

- Когда прибыльный сегмент лоялен с высоким уровнем использования, необходимо сосредоточить внимание на изменении лояльности в пользу бренда предприятия, 
- В условиях достаточного количества мелких пользователей лояльного бренда сосредоточение внимания на повышении скорости их использования корпоративного бренда является желательной стратегической реакцией,

- Если имеется достаточное количество крупных пользователей, которые просят разнообразия, эффективной реакцией будет использование бренда в качестве выдающегося атрибута и создание новых относительных конкурентных преимуществ.

- В случаях, когда многие пользователи просят разнообразия, а они маленькие, необходимо реагировать таким образом, чтобы название бренда стало важным атрибутом.

Стратегическое управление брендом будет более успешным, если решения по бренду основаны на стратегическом анализе. Он предоставляет основную информацию для принятия решений. Анализ, прежде всего, включает анализ рынка, клиентов, конкуренции и силы торговой марки. Информация, полученная в результате стратегического анализа, позволяет руководству сосредоточиться на клиентах. Бренд - это инструмент, который при осторожном использовании способствует созданию и поддержанию долгосрочных и прибыльных отношений с клиентами.

Вывод: Успешный бренд - важный стратегический инструмент предприятия. Он эффективно передает покупателям значение продукта и упрощает его идентификацию. Эффективное управление брендом включает в себя постоянное стремление предприятия выбирать способы реализации потенциала бренда и увеличения его стоимости. Результатом использования потенциала бренда является создание его лидерства в течение длительного периода за счет постоянных инвестиций в качество, коммуникацию, отношения с клиентами и межмаркетинг, как основу для создания устойчивого конкурентного преимущества и более успешного стратегического позиционирования предприятия. Основное послание руководству состоит в том, что бренд - это инструмент, а не только цель, и при его эффективном использовании он приводит к созданию очень ценных нематериальных активов - клиентского капитала.

\section{ЛИТЕРАТУРА}

1. Holt, D.B., Quelch,J.A., Taylor,E.L., How Global Brands Compete, Harvard Business Review, September 2004, pp. 68-75.

2. Котлер Ф., Келлер К.Л. Маркетинг менеджмент. 14-е издание. СПб. Питер, 2015. $800 \mathrm{c}$.

3. Keller, L.K., Strategic Brand Management, Building, Measuring, and Managing Brand Equity, second edition, Prentice Hall International, Inc. 2003.

4. Hill, S., Ettenson, R., Tyson, D., Achieving the Ideal Brand Portfolio, Sloan Management Review, Win-ter 2005, pp. 85-90.

5. Keller, K.L., Sternthal, B., Tybout, A., Three Questions You Need to Ask About Your Brand, Harvard Business Review, September 2002, pp. 81-86.

6. Centered Brand Management, Harvard Business Review, September 2004, pp. 110-118. 


\title{
STRATEGIC BRAND MANAGEMENT İN GLOBAL ENVİRONMENT
}

Khaliq Gurbanov

Azerbaijan State University of Oil and Industry, Chief Lecturer, Department of Economics and Management of Energy and Petrochemistry, Email: ibrahimovasadagat06@gmail.com

\begin{abstract}
In modern business conditions, the brand is essentially important for business strategy success. Customers increasingly purchase products on the basis of brand, reputation, and other immaterial attributes and less on the basis of their physical characteristics. A strong brand increases the level of customer satisfaction and loyalty, and efficiency of business strategy. Brand with great value in the market is an important asset of firm. In the paper, authors analyze the importance of strategic brand management in the conditions of global environment.

Keywords: brand, customer, equity, strategy, management, efficiency
\end{abstract}




\title{
ФОРМИРОВАНИЕ ЛИЗИНГОВЫХ МЕХАНИЗМОВ НА ПРОМЫШЛЕННЫХ ПРЕДПРИЯТИЯХ АЗЕРБАЙДЖАНСКИЙ ГОСУДАРСТВЕННЫЙ УНИВЕРСИТЕТ НЕФТИ И ПРОМЫШЛЕННОСТИ
}

\section{Садагат Ибрагимова}

Доцент, доктор философских экономических наук кафедры, «Экономики и менеджмента энергетики и нефтехимии», Email: ibrahimovasadagat06@gmail.com

\begin{abstract}
The modern world market for leasing operations is concentrated mainly in Western Europe, the USA and Japan. In many countries, issues related to the subjects of leasing relations are also resolved in different ways. In France, specialized financial institutions and banks are prohibited from leasing operations. Organizations with special permission from the Ministry of Economy for leasing transactions in Belgium

The most favorable conditions for the leasing market have been created in Germany, Ireland, USA, Great Britain, Norway and other countries. To stimulate leasing relationships in Ireland, leasing companies are given the opportunity to use accelerated depreciation and government subsidies. As a result, Ireland has become a world center for aircraft leasing, and the country has an international center for financial services.

By improving leasing operations and leasing tax regimes, EU countries are optimizing reporting forms. In Japan, financial leasing must meet two basic conditions: 1) the lease term is determined, the amount of lease payments is approximately equal to all the costs of acquiring the leased item and 2) the lease agreement is inviolable and cannot be terminated during its validity period.

The most influential factors in the formation of leasing services in the world are increased competition, which creates conditions for optimizing investments, insufficient liquidity and reduced profits, which limits the ability of companies to allocate the necessary financial resources to expand production.

For the effective implementation of leasing operations in our country, an effective tax policy must be formed for the development of leasing in the investment activities of organizations.

The more VAT is not levied on domestic equipment purchased by leasing companies, the greater the benefit.
\end{abstract}

Keywords: leasing market, leasing operations, leasing legislation, lease payments, efficient, domestic equipment, discounts.

\section{РЕЗЮМЕ}

Современный мировой рынок лизинговых операций сосредоточен в основном в Западной Европе, США и Японии. Во многих странах вопросы, связанные с предметами лизинговых отношений, также решаются по-разному. Во Франции специализированным финансовым учреждениям и банкам запрещено проводить лизинговые операции. Организации со специальным разрешением Министерства экономики на лизинговые сделки в Бельгии 
Наиболее благоприятные условия для рынка лизинга созданы в Германии, Ирландии, США, Великобритании, Норвегии и других странах. Для стимулирования лизинговых отношений в Ирландии лизинговым компаниям предоставляется возможность использовать режим ускоренной амортизации и государственные субсидии. В результате Ирландия стала мировым центром лизинга самолетов, а страна имеет международный центр финансовых услуг.

Улучшая лизинговые операции и налоговые режимы лизинга, страны ЕС оптимизируют формы отчетности. В Японии финансовый лизинг должен соответствовать двум основным условиям: 1) срок аренды определен, сумма лизинговых платежей примерно равна всем затратам на приобретение предмета лизинга и 2) договор аренды является неприкосновенным и не может быть прекращено в течение срока его действия.

Наиболее влиятельными факторами в формировании лизинговых услуг в мире являются усиление конкуренции, которая создает условия для оптимизации инвестиций, недостаточной ликвидности и снижения прибыли, что ограничивает возможности компаний выделять необходимые финансовые ресурсы для расширения производства.

Для эффективного осуществления лизинговых операций в нашей стране должна быть сформирована эффективная налоговая политика для развития лизинга в инвестиционной деятельности организаций.

Чем больше НДС не облагается отечественным оборудованием, приобретаемым лизинговыми компаниями, тем больше выгода.

Ключевые слова: рынок лизинга, лизинговые операции, лизинговое законодательство, лизинговые платежи, эффективное, отечественное оборудование, скидки.

В странах с развитой рыночной экономикой лизинговый сектор обеспечивает более половины финансовых ресурсов на рынке капитала. Роль лизинга незаменима в экономическом развитии ненефтяного сектора. Лизинг широко используется при реализации продукции как на внешнем, так и на внутреннем рынке. Ежегодно мир тратит 400 миллиардов долларов на лизинг новых машин и оборудования, а также оборудования. Направлено более долларов США. Это равно объему прямых иностранных инвестиций. Помимо самолетов, судов и автомобилей, объектами международного лизинга часто являются компьютерное оборудование, строительное оборудование, станки и оборудование.

Современный мировой рынок лизинговых операций сосредоточен в основном в Западной Европе, США и Японии. Во многих странах вопросы, связанные с предметами лизинговых отношений, также решаются по-разному. Во Франции специализированным финансовым учреждениям и банкам запрещено проводить лизинговые операции. Как правило, лизинговые компании изолированы от банков. В Бельгии лизинговые сделки могут заключать только организации, получившие лицензию Министерства экономики. Лизинговая компания в Италии должна иметь определенный капитал. В США существует четыре основных типа лизинговых компаний: - банки и их отделения; - независимые лизинговые компании; - специализированные направления лизинга производственных предприятий; - инвестиционные, брокерские и страховые организации. Одна из причин стремительного развития лизинговых отношений в США - введение налоговых льгот. Он состоит из 2 частей, включая инвестиционный налоговый кредит и ускоренную амортизацию. Здесь более распространен лизинг автотранспорта.

Особенности применения лизинга в Бельгии:

- Срок аренды не должен превышать срок службы имущества; 
- Имущество должно использоваться арендатором только в профессиональных целях;

- Недвижимость должна соответствовать требованиям арендатора и быть приобретена арендатором с целью последующей сдачи в аренду.

- Размер арендной платы определяется таким образом, чтобы позволить оплатить стоимость сданного в аренду имущества в течение срока действия договора.

В Великобритании договор считается арендой, если выполняются следующие условия:

- закрывается на срок не менее $75 \%$ срока службы имущества,

- предполагается, что стоимость имущества будет полностью оплачена в течение срока действия договора.

В Великобритании, если компания инвестирует в начале года, ей придется немного подождать, чтобы воспользоваться преимуществами. Но если компания продает оборудование лизинговой компании, а затем сдает его в аренду, то косвенный доход должен генерироваться быстрее. Поэтому лизинговые компании открывают филиалы в разное время года. Налоги, уплачиваемые лизинговыми компаниями в Великобритании: налог на капитал, налог на добавленную стоимость, налог на прибыль предприятий, местные налоги (особенно это налоги на недвижимость).

Особенности лизинга в Австрии:

- Периодические платежи в течение срока действия договора аренды должны быть номинальными;

- Срок действия договора аренды составляет 40-80\% от экономического срока службы имущества;

- Если собственность считается частной собственностью по договору аренды, то владельцем собственности считается пользователь.

Есть определенные подходы к сдаче недвижимости в аренду в Германии.

- Налог на имущество при финансовом лизинге уплачивается лизингополучателем, если его обычный срок использования превышает срок основного лизинга, и лизингополучатель имеет право продлить срок;

- Уплата налога на имущество во всех случаях производится арендатором или арендодателем в соответствии с условиями и т.д.

В Германии юридические условия лизинга формируются решениями налоговой службы и судебной практикой. Согласно Налоговому кодексу активы принадлежат законному владельцу, и в определенных случаях, если законный владелец не может повлиять на использование активов третьей стороны, этот актив учитывается экономическим владельцем.

Налоги, уплачиваемые лизинговыми компаниями в Германии: налог на прибыль, налог на капитал, налог на добавленную стоимость, налог на добычу полезных ископаемых, налог на имущество, торговый налог.

В целях стимулирования инвестиционного процесса в процессе интеграции посредством лизинговых операций в странах ЕС налоговые реформы проводятся в соответствии с принципами: отменено двойное налогообложение; страна, из которой получен доход, облагается налогом; предусмотрено снижение налоговых льгот; налоговые ставки устанавливаются в единой форме и применяются единые принципы расчета налоговой базы; В странах-партнерах устранена дискриминация в отношении капитала.

Страны ЕС продолжают совершенствовать методы начисления износа имущества, что положительно сказывается на лизинговых отношениях. Практически все страны используют режим быстрой амортизации. Это не только уменьшает налоговую базу, но и увеличивает амортизационные отчисления. 
Улучшая лизинговые операции и налоговые режимы лизинга, страны ЕС оптимизируют формы отчетности. Но все же в это время

В странах ЕС действуют как правовые, так и экономические концепции, когда имущество, передаваемое друг другу, учитывается в правовом и экономическом балансе предпринимателя. Экономический подход не принимает во внимание юридическое содержание договора, а только его экономическую природу. Арендованное имущество и его износ учитываются на балансе собственника при оперативном лизинге и на балансе пользователя имущества при финансовом лизинге. Эта система в основном используется в Великобритании, Ирландии, Нидерландах и Бельгии. Франция входит в пятерку крупнейших лизинговых стран мира и входит в тройку крупнейших в Европейском союзе. Лизинговые операции во Франции характеризуются тремя основными критериями: лизинг оборудования или недвижимости, лизинг для частных целей или профессиональный лизинг и необязательный лизинг с покупкой имущества, а также безопционный лизинг с покупкой имущества. Здесь в соответствии с законодательством финансовый лизинг применяется в определенных случаях:

- Арендодатель покупает оборудование до следующей сдачи в аренду;

- Арендодатель предоставляет арендатору покупную цену недвижимости по заранее согласованной цене.

- Арендованное оборудование используется для коммерческой деятельности и производства.

Согласно французскому Налоговому кодексу, только арендатор может амортизировать арендованные активы. Амортизация может производиться либо методом уменьшающегося остатка, либо прямым методом в некоторых случаях, разрешенных законом. Срок амортизации некоторых видов активов: тяжелое оборудование - 8 лет, сложное технологическое оборудование - 3 года, железнодорожный транспорт - 7 лет и другое оборудование - 5 лет. Основными видами налогов, уплачиваемых лизинговыми компаниями во Франции, являются косвенные налоги и налог на прибыль. Ставка налога на прибыль составляет $2 \%$ для чистой прибыли юридических лиц. НДС взимается со сделок по лизингу оборудования, стандартная ставка составляет 18,6\%.

В Японии финансовый лизинг должен соответствовать двум основным условиям: 1) срок аренды определен, сумма лизинговых платежей примерно равна всем затратам на приобретение предмета лизинга и 2) договор аренды является неразрывным и не может быть прекращено в течение срока его действия.

Финансовый лизинг рассматривается как сделка по продаже продукта, если выполняется один из вышеуказанных критериев: 1) в конце периода аренды арендованное имущество может быть сдано в аренду арендатору с нулевой или номинальной премией, 2) оборудование установлен в здании и не перемещен 3) срок аренды должен быть менее $70 \%$ установленного законодательством срока службы арендуемого имущества, при этом арендатор имеет право выкупа.

Государственное регулирование лизинговой деятельности имеет разные особенности в каждой стране. Когда лизинг считается особой функцией банков, они не только регулируют банковскую деятельность, но и контролируют процесс лизинга. В Германии и Великобритании банки контролируют только ту часть лизинговых операций, которую проводят их подчиненные. В других странах, а также во Франции управление лизинговыми операциями было значительно упрощено по сравнению с банковскими операциями [1]. 
Особые требования к механизму лизинга соблюдены законодательством США, Франции и Италии. Договоры аренды регистрируются в судах, цель которых - известить определенный круг лиц, предусмотренных законом, о собственнике арендуемого имущества. В Германии, Нидерландах, Великобритании и Дании аренда, как правило, не ограничивается и не регулируется одновременно.

Опыт показывает, что специальное законодательство не всегда имеет решающее значение для развития лизинга. Основная позиция здесь - макроэкономические условия страны, инвестиции и государственная поддержка лизинга как его основной формы. Наиболее благоприятные условия для рынка лизинга созданы в Германии, Ирландии, США, Великобритании, Норвегии и других странах. В Ирландии, например, лизинговым компаниям предлагается ускоренная амортизация и государственные субсидии для стимулирования лизинговых отношений. В результате Ирландия стала крупнейшим в мире центром лизинга самолетов и Международный центр финансовых услуг в стране.

Есть страны, где некоторые ограничения мешают развитию лизинга. В Греции, например, запрещена аренда грузовиков, автобусов и недвижимости.

Наиболее влиятельными факторами в формировании лизинговых услуг в мире являются: [2]

- Обострение конкуренции, что создает условия для оптимизации инвестиций;

- Недостаточная ликвидность;

- Снижение прибыли, что ограничивает возможности компаний выделять необходимые финансовые ресурсы для расширения производства.

Объекты лизинговых операций отличаются друг от друга в разных странах по своему весу. Например, в Италии и Франции на промышленное оборудование приходится 40-50\% лизинговых сделок, а в Германии на лизинговые сделки приходится $15 \%$ промышленного оборудования. Вместо этого основными объектами лизинговых сделок являются компьютеры и оргтехника - 11\% и автомобили - 50\%. [3]

В отраслевой структуре лизинговых операций в России основную долю составляют химическая и лесная продукция - 10\% и машиностроение - $11 \%$. В Японии большинство лизинговых операций связано с компьютерными продуктами и продуктами информационных систем. [4]

Около 60\% малого бизнеса в Азербайджане сданы в аренду. Суммарная доля комиссионных в общей сумме лизинговых платежей в нашей стране составляет в среднем $10 \%$. В настоящее время доля операций по лизингу грузовых автомобилей в портфеле лизинговых компаний выше. Около 60\% арендаторов в нашей стране - малые предприятия. Комиссия установлена в размере около 10\% от общей суммы арендных платежей. Доля сделок с грузовиками в портфеле лизинговых компаний выше.

Для достижения этой цели в сфере промышленного комплекса специализированные лизинговые компании выполняют следующие задачи:

- Получает в лизинг техническое оборудование для обслуживания клиентов в стране и за рубежом, а также привлекает для этого кредиты и депозиты.

- Проводит маркетинговые исследования приборов, машин, оборудования на внутреннем и международном рынках. Обслуживает клиентов путем выбора подходящих производственных технологий и инструментов.

Осуществляет различные лизинговые операции с движимым и недвижимым имуществом на внутреннем и внешнем рынках.

- Обеспечивает технико-экономическое развитие лизинговых проектов по запросам клиентов и дает консультации по различным вариантам лизинговых сделок. 
- Организует рекламу отечественных и зарубежных приборов и оборудования, участвует в организации выставок и ярмарок новой техники и технологий для развития лизинговых операций.

- Предоставляет клиентам всю необходимую научную, техническую, коммерческую и экономическую информацию. Монтаж и настройка сданного в аренду имущества помогает оказать услугу.

-Устанавливает отношения с местными и иностранными компаниями и международными лизинговыми ассоциациями, чтобы предоставлять своим клиентам высококачественные услуги.

- Предоставляет различные услуги по обучению в сфере лизинга.

Провести методологическую подготовку к осуществлению лизинговых операций в промышленном комплексе страны, выявить особенности, широко использовать зарубежный опыт, развивать формы договорных отношений на всех уровнях. Однако вовлечение банковской структуры в лизинг строительства остается сложным. На это есть основные причины:

- недостатки в процессе налогообложения лизинга;

- Несоответствия в законодательстве;

- Лизинг не получил широкого признания в качестве финансового инструмента;

- Недостаточный механизм и проекты поддержки лизингового сектора.

Бездействие банков в сфере строительства и лизинга строительства связано с отсутствием долгосрочных финансовых ресурсов, помимо причин, упомянутых выше. Это связано со следующими факторами: (5)

- Краткосрочный характер доверия к банкам;

- Низкий уровень капитализации банков;

- Отсутствие широкого использования инструментов рынка ценных бумаг.

Одной из причин пассивности банков в лизинговом секторе является недостаточная институциональная подготовленность банков и непрозрачность корпоративного сектора. [6]

Целесообразно принять определенные меры для стимулирования активности банков в лизинговом секторе:

- Завершение процесса совершенствования законодательства;

- Повышение финансовой прозрачности лизинговых компаний;

- Улучшение конкурентной среды;

- Увеличение долгосрочных финансовых ресурсов;

- Усиление защиты прав кредиторов и углубление судебной реформы.

Помимо создания нормативной базы и законодательной базы для привлечения финансовых ресурсов для инвестиций предприятий посредством лизинговых операций, должны быть созданы благоприятные условия с государственными гарантиями. Эти условия также включают валютное и таможенное регулирование лизинговых операций, налоговые льготы и т. Д. определяется.

Развитие лизинговых отношений в нашей стране показывает, что в настоящее время существует практика предоставления участникам лизинговых операций некоторых льгот по сравнению с другими видами предпринимательства. Закон определяет основные меры государственной поддержки лизингодателей.

- Освобождение от НДС при лизинговых операциях с сохранением существующего порядка уплаты НДС при покупке недвижимости;

- Освобождение от налога на прибыль по лизинговым операциям на срок не менее 3 лет; 
- Включение процентов на стоимость продукта в виде финансовых результатов, которые учитываются при удержании налога на прибыль, по кредитам организаций и банков, используемых лизинговой организацией для лизинговых платежей по финансовым лизинговым операциям и финансовым операциям. лизинговые операции;

- Освобождение от таможенных пошлин и налогов, хотя бы частично, продукции, временно ввозимой в страну, являющуюся объектом международного лизинга;

Для банков:

- Освобождение от налога на прибыль по кредитам, выданным сроком более 3 лет для осуществления операций финансового лизинга.

Для арендаторов:

- Уменьшение суммы налога на имущество, стоимости сданных в аренду объектов отражается в балансе арендаторов при переходе имущества в собственность арендатора после истечения срока действия договора аренды. До окончания договора аренды она зачисляется на баланс арендодателя.

- Снижение налога на прибыль организаций, лизинговые платежи включены в стоимость продукта. Кроме того, бухгалтерский учет арендатора упрощается, поскольку лизинговая организация ведет учет амортизации, основных средств, уплаты определенных налогов и одновременно погашения задолженности.

Для производителей лизингового оборудования:

- Увеличение доходов от продажи комплектующих и запасных частей к оборудованию, продаваемому в лизинг, а также модернизация предоставления услуг к нему.

Налоговые льготы в зарубежных странах - главный финансовый метод, который способствовал быстрому развитию лизинга. Чем больше будет уступок, тем быстрее будет развиваться лизинг.

Для эффективного осуществления лизинговых операций в нашей стране должна быть сформирована эффективная налоговая политика по развитию лизинга в инвестиционной деятельности организаций. Чем больше НДС не облагается отечественным оборудованием, приобретаемым лизинговыми компаниями, тем больше льгот.

Несмотря на важную роль финансовых методов государственной поддержки в совершенствовании лизинга в развитии лизинга в инвестиционной деятельности организаций, они не могут расширить его развитие без использования других форм государственной поддержки лизинга. Они включают:

- Выдача государственных гарантий на реализацию лизинговых проектов;

- Освобождение лизингодателей от налога на прибыль от реализации договоров финансового лизинга на срок не менее 3 лет;

- Предоставление права на амортизацию оборудования, сбор амортизационных отчислений и направление полученных средств на свою деятельность участникам лизинговых операций;

- Освобождение банков и иных кредитных организаций от налога на прибыль по ссудам, предоставленным на срок более 3 лет для осуществления операций финансового лизинга;

- Содействие в обучении и повышении квалификации персонала, работающего в сфере лизинговой деятельности;

- Реализация мероприятий по формированию и дальнейшему совершенствованию нормативно-правовой базы, направленных на защиту законных интересов участников лизинговой операции и др.

Модель оценки эффективности лизинга

- Выбор оптимального варианта лизинговой схемы,

- Расчет арендных платежей, 
- Планирование арендных платежей,

- Расчет показателей эффективности для арендодателя,

- Расчет показателей для сравнения эффективности проекта и предоставления недвижимости в лизинг,

Расчет показателей эффективности инвестиционного проекта с использованием лизинга,

- Планирование показателей экономической эффективности проекта в зависимости от условий договора,

• Определение пригодности проекта с помощью лизинга.

\section{ЛИТЕРАТУРА}

1. Кувшинова Е.С. Лизинг в сфере кредитно-инвестиционных отношений.// Наука управления:новые ориентиры в развитии: Сборн. статей./ Под общ. ред. А.Л.Гапоненко. М.: Изд-во РАГС, 2007.c. 220-230.

2. Crafts Nicholas Globalization and Growth in the Twentieth Century.// (IMF Working Paper WP00/44) Washington D.C.: International Monetary Fund, March 2012.

3. Amembal S. Emerging lease markets. London: Euromoney Publications, 2006. 450 p.

4. Gilyart S. Licensing and Supervision of leasing Activity.- International Leasing Resource. 2004, 280 p.

5. Leaseurope Annual Conference Materials.- Frankfurt: Leaseurope. 2004. $2151 \mathrm{p}$

6. Wong C. Equipment Leasing .- N.Y.: Matthew Bender, 2005. 225p.

\section{FORMATION OF LEASING MECHANISMS IN INDUSTRIAL ENTERPRISES}

\section{Sedaget Ibrahimova}

Azerbaijan State Oil and Industry University, "Economics and management of energy and petrochemical industries" Department, Associate-professor, Ph.D.

Email: ibrahimovasadagat06@gmail.com

\section{ABSTRACT}

The modern world market for leasing operations is concentrated mainly in Western Europe, the USA and Japan. In many countries, issues related to the subjects of leasing relations are also resolved in different ways. In France, specialized financial institutions and banks are prohibited from leasing operations. Organizations with special permission from the Ministry of Economy for leasing transactions in Belgium

The most favorable conditions for the leasing market have been created in Germany, Ireland, USA, Great Britain, Norway and other countries. To stimulate leasing relationships in Ireland, leasing companies are given the opportunity to use accelerated depreciation and government subsidies. As a result, Ireland has become a world center for aircraft leasing, and the country has an international center for financial services.

By improving leasing operations and leasing tax regimes, EU countries are optimizing reporting forms. In Japan, financial leasing must meet two basic conditions: 1) the lease term is determined, the amount of lease payments is approximately equal to all the costs of acquiring the 
leased item and 2) the lease agreement is inviolable and cannot be terminated during its validity period.

The most influential factors in the formation of leasing services in the world are increased competition, which creates conditions for optimizing investments, insufficient liquidity and reduced profits, which limits the ability of companies to allocate the necessary financial resources to expand production.

For the effective implementation of leasing operations in our country, an effective tax policy must be formed for the development of leasing in the investment activities of organizations.

The more VAT is not levied on domestic equipment purchased by leasing companies, the greater the benefit.

Keywords: leasing market, leasing operations, leasing legislation, lease payments, efficient, domestic equipment, discounts. 


\title{
ИССЛЕДОВАНИЕ ИМИТАЦИОННОЙ МОДЕЛИ СИСТЕМЫ БЕЗОПАСНОСТИ ИНФОРМАЦИИ В СЕТЯХ ОБСЛУЖИВАНИЯ
}

\author{
Балами Исмайлов \\ Национальная Академия Авиации, Доктор Технических Наук, Доцент. Азербайджан, \\ Email: balemi@ rambler.ru
}

\begin{abstract}
Information security systems (ISSS), including the N-th number of security features, are considered. The system is represented as a multichannel queuing system (QS) with a Poisson flow of requests at the entrance. The goal of building of its structure is pursued. At the same time, the process of servicing unauthorized access (SUA) request is also random. Security features in the ISS convert the source stream into streams of detected and skipped (undetected) unauthorized access requests.

A simulation model of the system in the GPSS language (General purpose simulation system), which is an algorithm describing the behavior of the QS, i.e. changes in the state of the system over time for given flows of orders arriving at the input of the system. Entry flows determine the external parameters of the system. The parameters of the output streams describe the property of the system functioning and are its output parameters. The output parameters of the system are considered the number of occupied devices in the system, the utilization rate of service devices, etc.

At the same time, for the performed runs of the imitation model, the characteristics of the ISS in the service networks are investigated and the following trends in its main characteristics are defined as:

- the number of occupied devices in the system;

- utilization rate of service devices in the system.

The revealed results show that, with detected and skipped requests in the system, the trend in the number of occupied devices in the system and the utilization rate of the service devices are respectively 1,$185 ; 0.720 ; 0.885 ; 2.000 ; 1500$ and $0.945 ; 0.443 ; 0.712 ; 0.978 ; 0.962$.

The obtained results confirm the assumptions made that the appearance of the missed and detected transacts depends on the length of the observation period. The results can be used in networks for various purposes.
\end{abstract}

Keywords: Information security systems, queuing systems, security features, unauthorized access.

\section{REZÜME}

N sayda müdafiə vasitəsindən ibarət informasiya təhlükəsizliyi sisteminə (ITSS) baxılmışdır. Sistemə girişində puasson axını olan çoxkanallı kütləvi xidmət sistemi (KXS) kimi baxılmışdır. Onun strukturunun qurulması məqsədi nəzərdə tutulur. İcazəsiz müdaxiləli (İM) xidmət prosesində - sorğular da təsadüfidir. İTS-də müdafiə vasitəsi ilkin axını aşkarlanmış və buraxılmış (aşkarlanmamış) İM sorğularına çevirir. İTS modeli işılənmiş, imitasiya eksperimenti aparılmış, alınmış nəticələr təhlil edilmişdir. 
Açar sözlər: İnformasiya təhlükəsizliyi sistemi, kütləvi xidmət sistemi, müdafiə vasitəsi, icazəsiz müdaxilə.

\section{PЕЗЮМЕ}

Рассмотрены системы безопасности информации (СБИ), включающие $\mathrm{N}$-е количество средств защиты. Система представляется как многоканальная система массового обслуживания (СМО), имеющая на входе пуассоновский поток заявок. Преследуется цель построения ее структуры. При этом процесс обслуживания несанкционированного доступа (НСД)-запроса также является случайным. Средства защиты в СБИ преобразуют исходный поток в потоки обнаруженных и пропущенных (необнаруженных) запросов НСД.

Разработана имитационная модель системы на языке GPSS (General purpose simulation system), представляющая собой алгоритм, описывающий поведение СМО, т.е. изменения состояния системы во времени при заданных потоках заявок, поступающих на вход системы. Входные потоки заявок определяют внешние параметры системы. Параметры выходных потоков описывают свойство функционирования системы и являются ее выходными параметрами. В качестве выходных параметров системы рассматривается количество занятых приборов в системе, коэффициент использования приборов обслуживания и т.д.

При этом для выполненных прогонов модели имитации исследованы характеристики СБИ в сетях обслуживания и определены следующие тенденции изменения основных ее характеристик как:

- количество занятых приборов в системе;

- коэффициент использования приборов обслуживания в системе.

Выявленные результаты показывают, что при обнаруженных и пропущенных запросах в системе тенденция изменения количества занятых приборов в системе и коэффициент использования приборов обслуживания соответственно составляют 1,$185 ; 0,720$; 0,$885 ; 2.000 ; 1500$ и 0,$945 ; 0,443 ; 0,712 ; 0.978 ; 0.962$.

Полученные результаты подтверждают сделанные предположение о том, что появление пропущенных и обнаруженных транзактов зависит от продолжительности периода наблюдения. Полученные результаты могут быть использованы в сетях различного назначения.

Ключевые слова: Системы безопасности информации, системы массового обслуживания, средства защиты, несанкционированный доступ.

Введение: Проблема, связанная с созданием СБИ в сетях обслуживания, является одной из актуальных задач. В литературе известны работы, в которых изучается характер негативных воздействий на сети обслуживания [1-5]. Воздействия на сети обслуживания осуществляются, в основном, из глобальной сети Internet, являющиеся не только средством поиска информации, но, к сожалению, и средой распространения вирусов. СБИ в сетях обслуживания создаются между различного рода сетями обслуживания с одной стороны и глобальной сетью с другой. Это своего рода межсетевой шлюз (gateway), в функции которого входит инспекция и фильтрация проходящей через него информации. Такая структура межсетевых соединений позволяет резко снизить угрозы НСД в сетях обслуживания за счет использования способа "маскарада" (masquerading), т.е. когда весь исходящий из сети обслуживания трафик посылается от имени СБИ, делая сети практически «невидимыми» [1]. 
Кроме того, в проблеме информационной безопасности сетей возникают задачи построения структуры систем безопасности, включающие современные технические и программные средства с целью контроля передаваемой информации. СБИ, в основном, содержит комплекс программ, требующих определенного объема памяти [1-3].

В литературе предложены различные подходы по исследованию характеристик СБИ в сетях обслуживания для нахождения оптимальной структуры СБИ [1-4]. Для решения задачи исследования характеристик СБИ в [1] использован метод обобщенного приведенного градиента и в качестве показателя эффективности, выбрано математическое ожидание вероятности потери от несвоевременного распределения сообщений после фильтрации в сети.

В [5,6] рассмотрены математические модели аппаратно-программного комплекса защиты информации от несанкционированного доступа.

Отметим что в отличие от $[1,5,6]$ здесь, в основном, рассматривается модели СБИ от НСД в сетях обслуживания, представляющие собой $\mathrm{N}-$ е количество средств защиты (C3) с ограниченной очередью и учитывающие пропущенные (необнаруженные) запросы НСД. Они взаимодействует с потоками случайных событий - попыток НСД, которые обусловлены не только действиями злоумышленников, но и ошибками в программнотехнических комплексах.

СБИ выполняют следующие функции:

- осуществляют защиту от злоумышленников;

- выполняют попытки обнаружения НСД;

- проводят действия по их классификации;

- дают соответствующие решения для блокирования НСД.

В [2] отмечено, что подобный процесс, т.е. попытки НСД в сети могут быть описаны неординарными случайными потоками.

В [6] с целью упрощения модели рассмотрен ординарный рекуррентный поток попыток НСД. Отметим, что несанкционированные запросы на обслуживание возникают не только по причине действия злоумышленника, но и в силу следующих причин:

- ошибок программного обеспечения;

- неправильной настройки прав доступа;

- несоответствия условий эксплуатаций СБИ требованиям технических условий.

В модели процесс обслуживание НСД-запроса можно считать случайным исходя из следующих причин:

- случайность момента появления запросов;

- случайность состояния процесса обработки в этот момент и случайность возможных его состояний в последующие моменты времени.

Исходя из изложенных выше положений, структуру исходной модели СБИ от НСД можно предоставит в следующем виде (рис.1). 


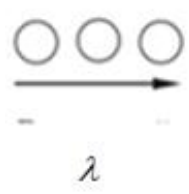

запросы от НСД

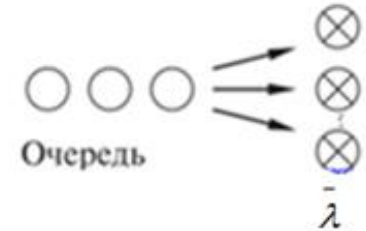

средства зашнты

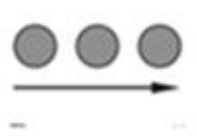

зашншаемые ресурсы

\section{снстемы безопасностн}

ннформацни

Рисунок 1. Структура модели СБИ от НСД

В системе злоумышленник не подвергается входному воздействию, но старается осуществить различные угрозы в сети обслуживания. Поступающие запросы от НСД появляются с интенсивностью $\lambda$ на входе СБИ, включающие $\mathrm{N}$-е количество С3. Средства защиты преобразуют исходный поток НСД в потоки обнаруженных и пропущенных (т.е. разреженных) запросов НСД с интенсивностью $\bar{\lambda}$. Каждый СЗ в СБИ характеризуется вероятностью пропуска НСД и вероятностью обеспечения защиты.

Если рассматривать средства защиты, функционирующие в СБИ как обслуживающие приборы, а поступающие запросы НСД как требования, то СБИ в целом можно рассматривать как многоканальную систему массового обслуживания, которая приведена на рис. 2 .

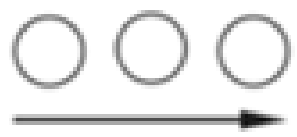

Входящий потоК

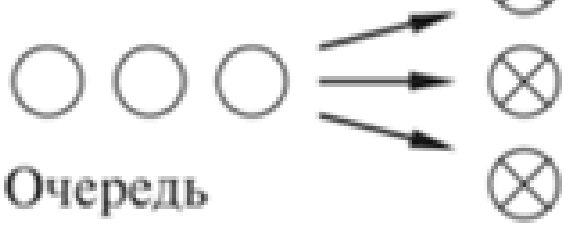

Обслуживающие приборы

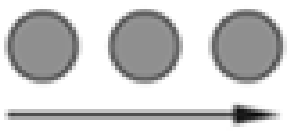

Выходящий поток

Рисунок 2. Многоканальную систему массового обслуживания

Разработана имитационная модель системы на языке GPSS (General purpose simulation system), представляющая собой алгоритм, описывающий поведение СМО, т.е. изменения состояния системы во времени при заданных потоках заявок, поступающих на вход системы. Входные потоки заявок определяют внешние параметры системы. Параметры выходных потоков описывают свойство функционирования системы и являются ее выходными параметрами. В качестве выходных параметров системы рассматривается количество занятых приборов в системе, коэффициент использования приборов обслуживания и т.д. 


\section{2.Алгоритм имитационной модели СБИ}

Рассматривается многоканальная $\mathrm{CMO}$, включающая в качестве обслуживающих приборов $\mathrm{N}$-е количество С3 с ограниченной очередью и в качестве транзактов поступающие запросы НСД. Состояние СMO характеризуется состояниями обслуживающих приборов, транзактов и очередей в приборах обслуживания. Состояние приборов обслуживания характеризуется логической переменной, значения которой определяется как «занят» или «свободен». Переменная, описывающая состояние транзакта, может иметь значения «обслуживания» или «ожидания». Состояние очереди определяется количеством находящихся в ней транзактов.

Предполагается, что количество поступлений злоумышленника в течение определенного периода времени зависит только от продолжительности периода наблюдения. Средняя интенсивность поступления злоумышленников определяется по пуассоновскому закону [6] .

С целью построения имитационной модели СБИ от НСД разработаны алгоритмы построения имитационное модели СБИ в сетях обслуживания, которые включают в себя следующие пункты:

1) генерацию транзактов с целью имитации поступления запросов НСД;

2) если имеется свободное СЗ в СБИ - входящие транзакты пропускаются в систему, в противном случае осуществляется переход к пункту 6;

3) организация очереди для имитации буфера запросов С3;

4) осуществление задержки с целью имитации обработки С3 поступающих запросов НСД;

5) осуществляется уничтожение транзактов для ликвидации запросов НСД как пропущенных, так и отсеянных С3;

6) проверяется значение вероятности пропуска НСД (например 0,1) и вероятности обеспечения защиты(например 0,9), т.е. в зависимости от поставленных значений этих вероятностей в алгоритме либо транзакт уничтожается, либо осуществляется переход к пункту 2.

На основе данного алгоритма на языке GPSS разработана имитационная модель СБИ и получены результаты, представленые на рис.3 для пяти прогонов.

При этом для выполненных прогонов модели имитации исследованы характеристики СБИ в сетях обслуживания и определены следующие тенденции изменения основных ее характеристик как:

- количество занятых приборов в системе;

- коэффициент использования приборов обслуживания в системе.

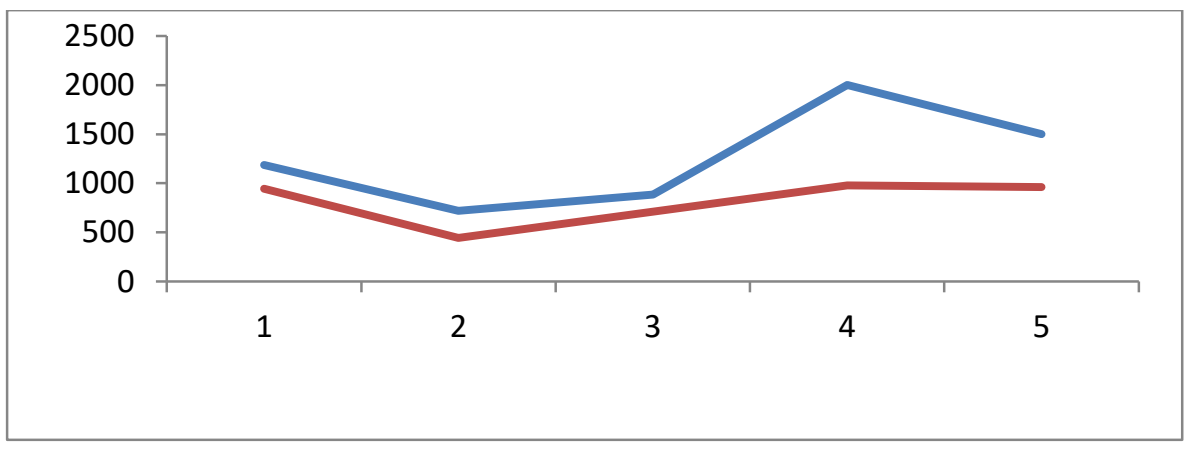


количество прогонов

Рисунок 4. Тенденции изменения количество занятых приборов (голубая линия) в системе и коэффициент использования приборов обслуживания (красная линия) (масштаб1:1000)

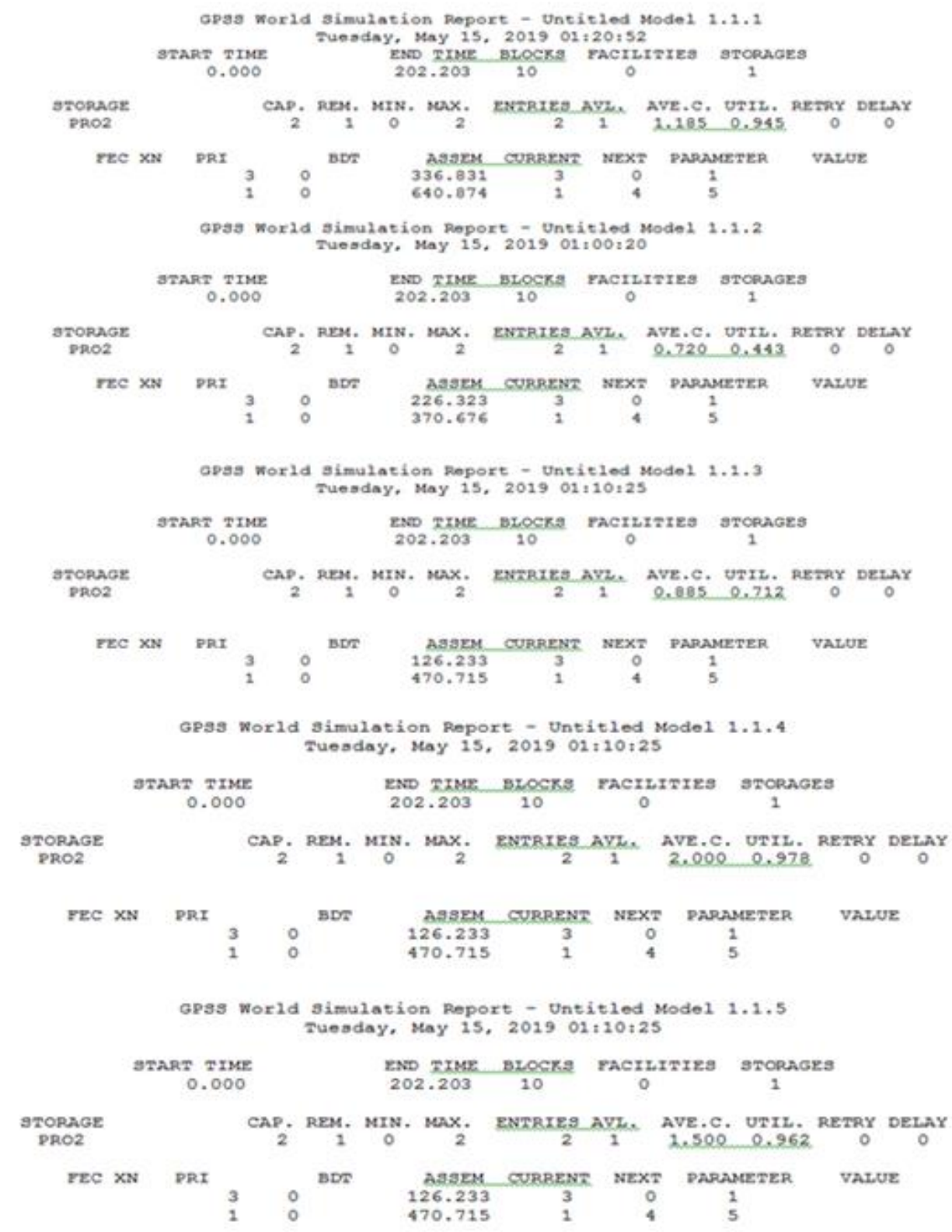

Рисунок 3. Результаты имитационной модели СБИ

Выявленные результаты показывают, что при обнаруженных и пропущенных запросах в системе тенденция изменения количества занятых приборов в системе и коэффициент использования приборов обслуживания соответственно составляют 1,$185 ; 0,720$; 0,$885 ; 2.000 ; 1500$ и 0,$945 ; 0,443 ; 0,712 ; 0.978 ; 0.962$ (рис.4). 
Полученные результаты подтверждают сделанные предположение о том, что появление пропущенных и обнаруженных транзактов зависит от продолжительности периода наблюдения. Полученные результаты могут быть использованы в сетях различного назначения.

Заключение: Предложен подход к исследованию характеристик СБИ в сетях обслуживания. Разработаны алгоритмы и модели исследования характеристик СБИ, проведены имитационные эксперименты и получены соответствующие результаты. Последние могут быть использованы при построении новых или модификации существующих СБИ в сетях различного назначения.

\section{ЛИТЕРАТУРА}

1. Б.Г. Исмайлов Исследование характеристик систем защиты информации распределенной сети// Автоматика и Вычислительная Техника. Рига, 2006, №3, c.51-59.

2. В.А. Герасименко, А.А. Малюк Основы защиты информации. М.: Наука, 1997, 224 c.

3. E.Gelenbe, P.Glynn, K.Sigmann Queues with negative arrivals// J.Appl.Prob.1991.V 28.pp.245- 250.

4. Р.Манзо, Н.Касконе , Р.В. Разумчик Экспоненциальная система массового обслуживания с отрицательными заявками и бункером для вытесненных заявок.Автоматика иТелемеханика,2008,вып.9,103-113с.

5. В. В. Карпов Вероятностная модель оценки защищенности средств вычислительной техники с аппаратно-программным комплексом защиты информации от несанкционированного доступа. «Программные продукты и системы » № 1, 2003 с.31-36.

6. В.А. Герасименко, А. В. Карпов Имитационная модель системы защиты информации.«Программные продукты и системы » № 2, 2005 с.26-30.

\section{STUDYING THE IMITATION MODEL OF THE SYSTEM SECURITY INFORMATION IN SERVICE NETWORKS}

Balami İsma1lov

National Aviation Academy, Doctor of technical sciences, Associate professor, Azerbaijan. Email: balemi@rambler.ru

\section{ABSTRACT}

A simulation model of the system in the GPSS language (General purpose simulation system), which is an algorithm describing the behavior of the QS, i.e. changes in the state of the system over time for given flows of orders arriving at the input of the system. Entry flows determine the external parameters of the system. The parameters of the output streams describe the property of 
the system functioning and are its output parameters. The output parameters of the system are considered the number of occupied devices in the system, the utilization rate of service devices, etc.

At the same time, for the performed runs of the imitation model, the characteristics of the ISS in the service networks are investigated and the following trends in its main characteristics are defined as:

- the number of occupied devices in the system;

- utilization rate of service devices in the system.

The revealed results show that, with detected and skipped requests in the system, the trend in the number of occupied devices in the system and the utilization rate of the service devices are respectively 1,$185 ; 0.720 ; 0.885 ; 2.000 ; 1500$ and $0.945 ; 0.443 ; 0.712 ; 0.978 ; 0.962$.

The obtained results confirm the assumptions made that the appearance of the missed and detected transacts depends on the length of the observation period. The results can be used in networks for various purposes.

Keywords: Information security systems, queuing systems, security features, unauthorized access. 


\title{
К ВОПРОСУ ОБ УСТОЙЧИВОСТИ ФУНКЦИОНИРОВАНИЯ МИКРОПРОЦЕССОРНЫХ РЕЛЕЙНЫХ ЗАЩИТ ЭЛЕКТРОДВИГАТЕЛЕЙ
}

\author{
${ }^{1}$ Николай Кургузов, ${ }^{2}$ Людмила Кургузова, ${ }^{3}$ Марина Кургузова \\ ${ }^{1}$ Торайгыровский университет. Кандидат технических наук. Профессор (Казахстан) \\ ${ }^{2}$ Торайгыровский университет. Кандидат технических наук. Доцент (Казахстан) \\ ${ }^{3}$ Электроэнергетический институт TELPRO. Инженер-электрик, Главный специалист (Казахстан) \\ E-mail: nic2_1950@mail.ru
}

\section{ВВЕДЕНИЕ}

Современный этап развития электроэнергетики Казахстана, России и других стран Содружества Независимых Государств характеризуется повсеместным обновлением электрического оборудования. Это касается и вводимых в эксплуатацию новых объектов, и реконструируемых, причем оборудования как первичных, так и вторичных цепей. В части релейной защиты (Р3) электроустановок обновление характеризуется переходом от устройств на аналоговой элементной базе к цифровым устройствам - терминалам микропроцессорных релейных защит (МПРЗ).

Следует заметить, что с переходом Р3 на цифровую технику эксплуатация связывала определенные надежды на более высокий уровень технического совершенства селективности и устойчивости несрабатывания в режимах без КЗ и в режимах внешних КЗ [1]. Однако излишние и ложные срабатывания оказались, к сожалению, присущими и МПРЗ, в частности, дифференциальным токовым защитам (ДЗ) - основным защитам электродвигателей, трансформаторов и сборных шин [2,3].

Настоящая работа посвящена анализу причин ложных срабатываний ДЗ мощных синхронных электродвигателей (СД) типа СТД-8000, выполненных на терминалах МПРЗ.

Ключевые слова: Синхронный электродвигатель, пусковой режим, микропроцессорная релейная защита, устойчивость функционирования.

Основная часть: СД типа СТД- 8000 номинальной мощностью 8000 кВт и номинальным напряжением 10 кВ используются, в частности, на нефтеперекачивающих станциях для привода нефтяных магистральных насосов типа НМ-10000-210. Эти насосы обеспечивают повышение напора транспортируемой нефти для ее дальнейшего перекачивания.

Для защиты, измерений, контроля и управления электродвигателями на нефтеперекачивающих станциях используются терминалы серии Sepam 2000. Терминалы обеспечивают защиту СД от всех видов повреждений и ненормальных режимов. Основной защитой от междуфазных КЗ в указанных терминалах является продольная ДЗ (код ANSI 87M).

В эксплуатации неоднократно [4] отмечались случаи ложных срабатываний СД типа СТД8000 в переходных режимах прямого пуска, сопровождаемых прохождением значительных токов небаланса. Следует заметить, что переходные токи небаланса не всегда вызывают нештатную работу ДЗ. На рис. 1 - 3 приведены осциллограммы успешного и неуспешных пусков СД. Проанализируем работу СД и ее ДЗ в переходных 
режимах прямого пуска с использованием приложения FastView 4.2 НТЦ «Механотроника» для отображения осциллограмм, расчета и анализа сигналов.

Рассмотрим осциллограмму успешного пуска СД типа СТД-8000 (рис. 1). На осциллограмме приведены кривые изменения во времени мгновенных значений:

- линейного напряжения питающей сети;

- вторичных токов $i_{2,1 A}$ первого плеча и $i_{2,2 A}$ второго плеча фазы А защиты;

- вторичных токов $i_{2,1 C}$ первого плеча и $i_{2,2 C}$ второго плеча фазы С защиты;

- тока небаланса $i_{н б A}$ фазы А защиты;

- тока небаланса $i_{н б С}$ фазы С защиты.

Включение СД в сеть сопровождается снижением питающего напряжения, что обусловлено значительным пусковым током (паспортное значение кратности пускового тока СД - 6,93). В момент включения СД в сеть в фазах А и С обмотки статора пусковой ток содержит как вынужденные, так и апериодически затухающие свободные составляющие. Апериодические составляющие пускового тока в фазах А и С обмотки статора выводят сердечники более нагруженных трансформаторов тока (ТT) второго плеча ДЗ в насыщение уже в первый период.

Пока сердечники менее нагруженных ТТ первого плеча ДЗ еще не насыщены, токи небаланса в фазах А и С защиты в первый и второй периоды переходного процесса пуска СД имеют однополярный характер (без полуволн обратного знака). В амплитуде эти токи достигают значений, близких к $3 \mathrm{~A}$.

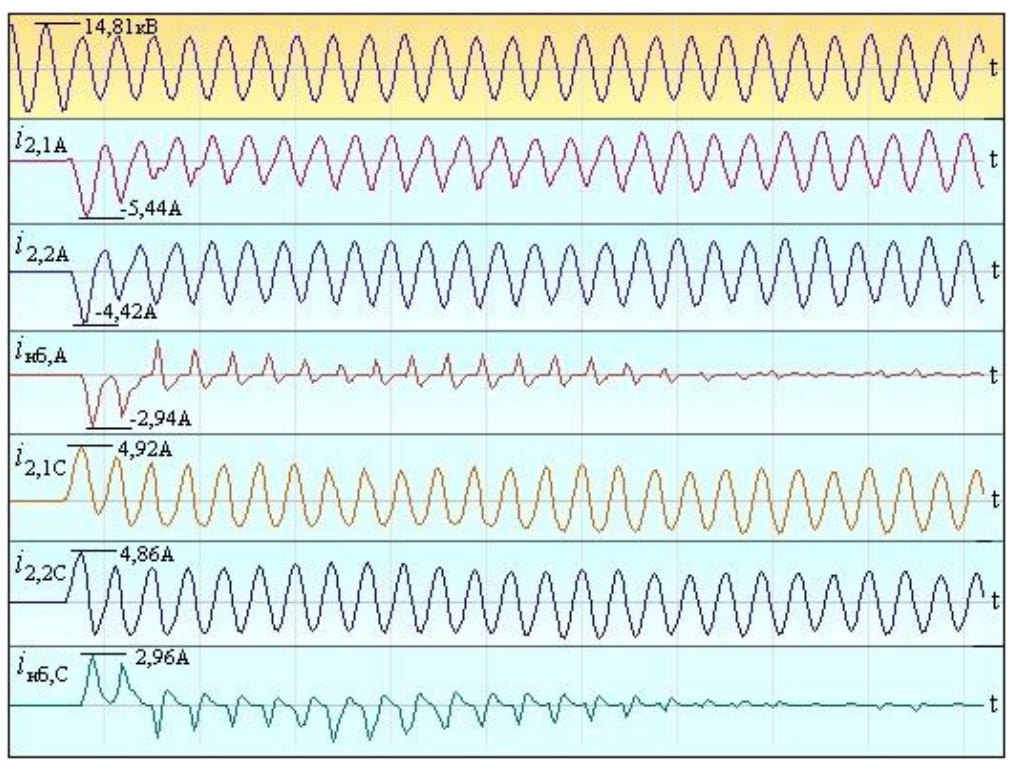

Рисунок 1 Осциллограмма успешного пуска СД

После насыщения сердечников ТТ первого плеча ДЗ апериодической составляющей пускового тока, начиная с 3-его периода в токах небаланса появляются полуволны обратного знака. По мере затухания апериодической составляющей пускового тока сердечники ТТ обоих плеч ДЗ выходят из насыщения, что приводит к снижению тока небаланса. 
Последующее вхождение сердечников ТТ плеч ДЗ в область насыщения, обусловленное действием свободного тока переменной частоты [5] в фазах А и С обмотки статора СД, приводит к повторному и более продолжительному протеканию тока небаланса. Токи небаланса также имеют полуволны обоих знаков, хотя их значения существенно меньше первоначальных значений. Ложного срабатывания МПРЗ в указанном режиме пуска не происходит.

Рассмотрим пуск СД с первым случаем неуспешного пуска СД. На рис. 2 приведена осциллограмма ложной работы ДЗ. В отличие от первого пускового режима, во втором случае апериодическая составляющая пускового тока в фазе А обмотки статора выводит в область насыщения сердечники ТТ только на второй период. Начиная с третьего периода, насыщение поддерживается нарастающим по величине током переменной частоты. Ток небаланса в фазе А защиты при этом имеет полуволны обоих знаков. Продолжительность глубокого насыщения сердечников ТТ током переменной частоты 0,22 с, в амплитуде ток небаланса достигает 1,57А.

Апериодическая составляющая пускового тока в фазе С обмотки статора СД выводит в насыщение сердечники ТТ второго плеча ДЗ уже во второй период. В амплитуде однополярный ток небаланса достигает значения 3,94А. Знакопеременный ток небаланса имеет место в третий и последующие периоды переходного процесса пуска СД, когда насыщение сердечников ТТ поддерживается током переменной частоты. По мере затухания тока переменной частоты, сердечники ТТ выходят из режима насыщения и ток небаланса уменьшается. Однако длительное протекание значительного по величине знакопеременного тока небаланса привело к ложному срабатыванию ДЗ и отключению СД от питающей сети.

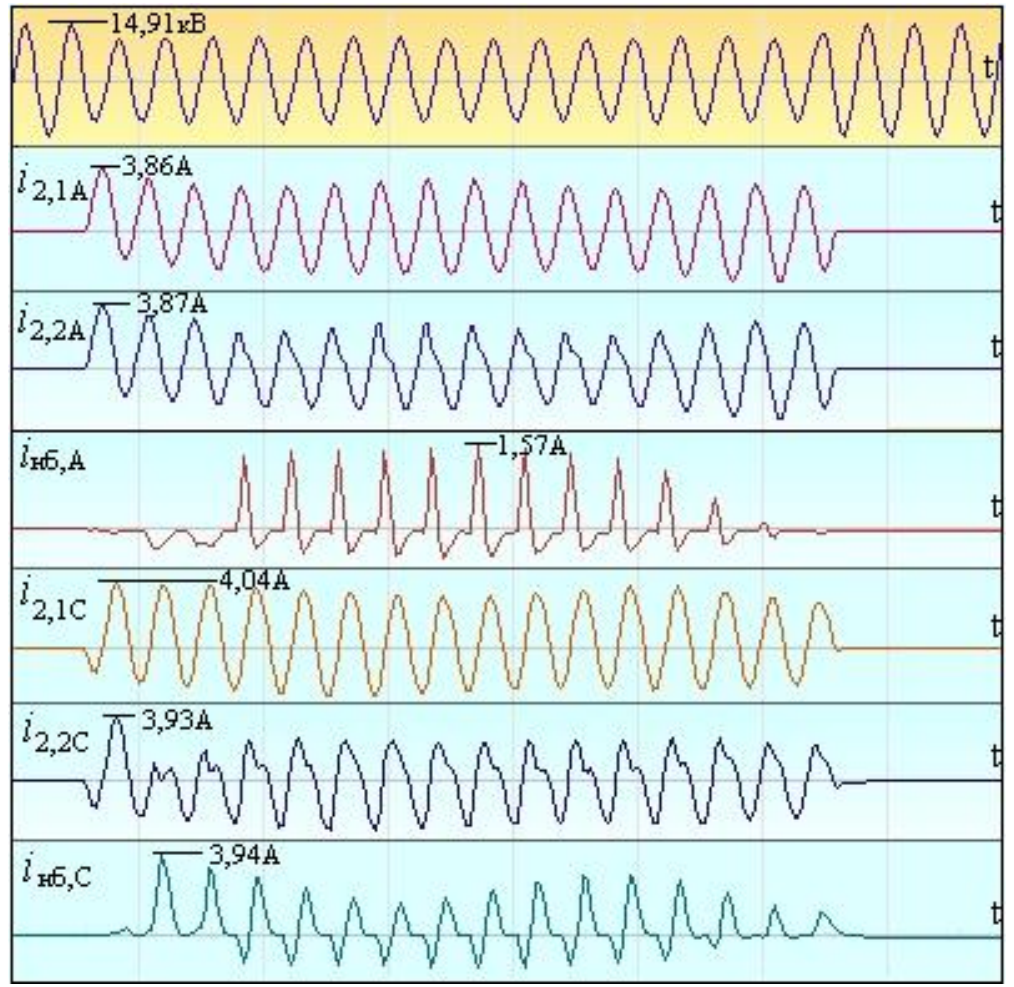


Рисунок 2 Осциллограмма первого ложного срабатывания ДЗ

Проведенные в [4] эксперименты показали, что глубокое насыщение сердечников ТТ может иметь место уже в первый период переходного процесса пуска СД. На рис. 3 приведена осциллограмма второго неуспешного пуска СД, вызванного ложным срабатыванием МПРЗ.

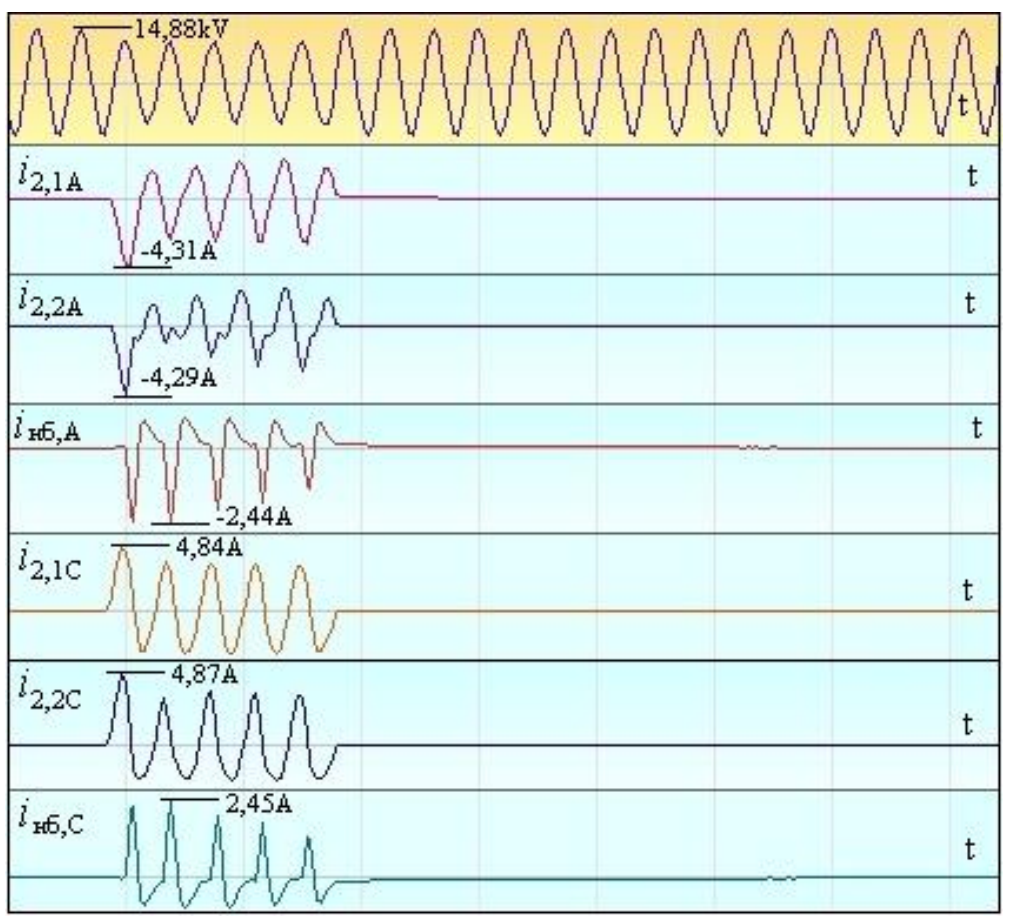

Рисунок 3 Осциллограмма второго ложного срабатывания ДЗ

Апериодическая составляющая тока в фазе А обмотки статора СД уже в первый период переходного процесса пуска выводит в область насыщения сердечники ТТ обоих плеч ДЗ. Поэтому, начиная с первого периода, ток небаланса имеет знакопеременный характер. Наибольшее насыщение сердечников ТТ и максимальный ток небаланса наблюдается во второй период (в амплитуде достигает значения - 2,44A).

Аналогичным образом апериодическая составляющая в пусковом токе фазы С обмотки статора СД действует на сердечники соответствующей фазы ДЗ. Ложное действие ДЗ в этом режиме обусловлено глубоким насыщением сердечников ТТ апериодической составляющей пускового тока СД.

Заключение: 1. Проведенный анализ поведения МПРЗ в переходных режимах пуска СД показал возможность нарушения устойчивости функционирования продольных ДЗ.

2.Ложные срабатывания терминалов Sepam 2000 обусловлены значительными переходными токами небаланса ДЗ в результате глубокого насыщения сердечников ТТ апериодическими составляющими пускового тока и токами переменной частоты в начальный период пуска СД.

3. Полноценный учет всех факторов, влияющих на устойчивость функционирования ДЗ, позволит исключить ложную работу защит, выполненных на любой элементной базе, в том числе МПРЗ. 


\title{
ЛИТЕРАТУРА
}

1. Федосеев М.А. Релейная защита электрических систем. - М.: Энергия, 1976, 560 с.

2. Кужеков С.Л., Нудельман Г.С. Обеспечение правильной работы микропроцессорных устройств дифференциальной защиты при насыщении трансформаторов тока // Известия вузов. Электромеханика. 2009. № 4. С. 12-18

3. Kuzhekov S.L., Degtyarev A.A. On the coordination of Current Transformers and Relay Protection and Automation operation of Electric-Power Systems in transient ShortCircuit states // Russian Electrical Engineering. 2017. T. 88. № 12. Pp. 832-838.

4. Ложная работа дифференциальной защиты при пуске синхронного двигателя. Форум: Советы бывалого релейщика. [Электронный pecypc] //URL: www.rzia.ru/topic6781-lozhnaya-rabota-diffzashchity-pri-puske-sinkhronnogodvigatelya.html (Дата обращения: 25.01.2017).

5. Богдан А.В., Кургузов Н.Н., Кургузова Л.И. Токи небаланса дифференциальных защит мощных электродвигателей // Электрические станции. 1980. №9. С. 46-50.

\section{TO THE QUESTION OF FUNCTIONAL STABILITY MICROPROCESSOR RELAY PROTECTION OF ELECTRIC MOTORS}

\author{
${ }^{1}$ Nikolay Kurguzov, ${ }^{2}$ Lyudmila Kurguzova, ${ }^{3}$ Marina Kurguzova \\ ${ }^{1}$ Toraighyrov University. Candidate of technical Science. Professor (Kazakhstan) \\ ${ }^{2}$ Toraighyrov University. Candidate of technical Science. Associate Professor (Kazakhstan) \\ ${ }^{3}$ Electrical Design Institute TELPRO. Engineer-electrician, Chief specialist (Kazakhstan) \\ E-mail: nic2_1950@mail.ru
}

\begin{abstract}
The current stage of development of the electric power industry in Kazakhstan, Russia and other countries of the Commonwealth of Independent States is characterized by the widespread renewal of electrical equipment. This applies to both new facilities being commissioned, and reconstructed ones, both primary and secondary circuit equipment. In terms of relay protection (RP) of electrical installations, the update is characterized by a transition from devices based on an analog element base to digital devices - microprocessor relay protection terminals (MPRZ).

It should be noted that with the transition of relay protection to digital technology, the operation pinned certain hopes for a higher level of technical perfection - selectivity and stability of failure in modes without short-circuit and in modes of external short-circuit [1]. However, unfortunately, unnecessary and false alarms turned out to be inherent in the MPRZ, in particular, differential current protection (DZ) - the main protection of electric motors, transformers and busbars [2,3].

This work is devoted to the analysis of the causes of false triggering of the remote sensing power of powerful synchronous electric motors (SD) of the STD-8000 type, performed at the MPRZ terminals.
\end{abstract}

Keywords: Synchronous electric motor, starting mode, microprocessor relay protection, stability of functioning. 


\title{
ПУТИ ПОВЫШЕНИЯ ЭФФЕКТИВНОСТИ ИСПОЛЬЗОВАНИЯ НЕФТЯНЫХ РЕСУРСОВ
}

\author{
Арзу Миргейдарова
}

Азербайджанский государственный университет нефти и промышленности, канд,,техн,,наук, доцент кафедры «Экономика и менеджмент отраслей энергии и нефтехимии», Азербайджан.

E-mail: arzu.mirgeydarova@mail.ru

\begin{abstract}
This article talks about the current state of the oil fields of the Republic of Azerbaijan. Information is given on the development of oil fields in Azerbaijan, which are at a late stage of development. A mathematical model is presented that characterizes the world oil production situation depending on reserves and the number of wells. A comprehensive systematic analysis is carried out for the SOCAR fields as a whole, after which the reasons for the deterioration of the main technical and economic indicators are identified and measures are proposed to identify reserves and factors for improving these indicators.

Ключевые слова: oil production, economic efficiency, late stage of development, oil reserves
\end{abstract}

В настоящее время с целью стабилизации и увеличения добычи нефти на месторождениях Апшеронского полуострова применяются в большом объеме ГТМ, в том числе различные методы обработки призабойной зоны скважин, ввод новых скважин для уплотнения сетки разработки.

Внедрение этих мероприятий требует большого объема капитальных вложений и эксплуатационных затрат. Кроме сказанного, необходимо отметить, что эффективность вышеназванных методов является в неудовлетворительном уровне. Поэтому применение этих методов сопровождается с определенным риском, который связан с неполнотой информации.

Как показывает анализ, в условиях недостаточной информации повышение уровня добычи нефти на месторождениях, находящихся в поздней стадии разработки и эффективность доразработки в значительной степени зависит от обоснованного выбора различных видов и условий ГТМ, становится актуальной разработка методики определения оптимальных значений совокупности факторов, характеризующих условия проведения этих мероприятий.

Исследованию экономической проблемы увеличения добычи нефти, замедления темпа увеличения себестоимости добычи нефти и совершенствования перспективного и текущего планирования капитальных вложений, повышения их эффективности посвящены труды ученых-экономистов А.А.Надирова, З.А.Самедзаде, А.Ф.Мусаева, Ю.М.Мурадова, Т.Н.Алиева, М.Д.Атакишиева, Ю.А.Самедзаде, Г.А.Сафарова, Э.М.Гаджизаде В.Е.Тищенко, Ю.М.Малышева, М.М.Саттарова, И.И.Рыженкова и др.

Основные вопросы проблемы интенсификации нефтедобычи на месторождениях, находящихся в поздней стадии разработки пластов, широко освещены в трудах ученых А.Х.Мирзаджанзаде, Л.П.Гужновского, Ш.К.Гиматудинова, Э.А.Дадаева, И.М.Муравьева, Т.Ч.Шейдаева и др. Вместе с тем, в исследованиях, проводимых в этом направлении, еще имеются нерешенные вопросы вызываемые практикой хозяйствования. Все вышеизложенное определило выбор темы статьи.

Формирование государственной энергетической политики и эффективное управление нефтегазовым комплексом и перспективами его развития невозможно без тщательного и 
кропотливого изучения исторического наследия и результатов деятельности, всесторонней и реальной оценки его нынешнего состояния на основе системного анализа всех звеньев и экономических составляющих производственного процесса (1).

Огромный фактический материал, накопленный за всю историю добычи нефти, позволил нам, учитывая, прежде всего, такие факторы, как хозяйственный уклад, общественнополитическую и экономическую системы, уровень развития промышленного производства, техники, технологии и науки, характер экономических, производственных отношений и производительных сил разделить историю нефтедобычи Азербайджана, по крайне мере, на четыре периода:

первый - доисторический, охватывающий временной период от первых упоминаний о нефти в древности до середины XIX века и характеризующийся потребительским отношением к нефти, как к естественному продукту, природные качества которого позволяли использовать его в быту;

второй - ранний этап начала промышленного производства (середина XIX века - 1920 год), характеризующийся хаотическим, бессистемным и хищническим подходом к добыче нефти;

третий - период с 1920 по 1991 год, характеризующийся достаточно широким использованием научно, технически и технологически обоснованных программ развития добычи нефти на основе планового ведения производства с ярко выраженными командноадминистративными методами управления;

четвертый - современный период интенсивного развития добычи нефти на основе рыночных принципов экономики с учетом национальных и геополитических интересов страны (2).

Первые попытки добычи нефти в Каспийском море относятся к XIX веку. Несмотря на существующие объективные трудности, в результате целенаправленной внутренней и внешней политики последних лет Азербайджан начинает занимать достойное место в мировом сообществе, закрепляются демократические принципы и создается правовое государство, развиваются рыночные отношения в экономике. Сейчас, оглядываясь в прошлое, можно с уверенностью сказать, что созданы условия для поднятия нефтяной промышленности на новую ступень за счет привлечения инвестиций и расширения внешне-экономических связей. Вместе с тем, основные проблемы нефтяной и газовой промышленности следующие:

- Осложнение условий нефтедобычи в связи с вовлечением в разработку залежей, находящихся в глубине и перспективных структур;

- Отсутствие техники и технологии, обеспечивающей безопасность и надежность работ по освоению залежей, находящихся в глубине;

- Важность привлечения значительных капитальных вложений для увеличения объема поисково-разведочных работ и добычи нефти и газа;

- Использование надежных и эффективных способов экспорта азербайджанской нефти на мировой рынок.

Общей проблемой в нефтяной и газовой промышленности является увеличение экономической эффективности производства. Решение этой проблемы основывается на инженерное решение, новые научно-технические достижения. Решение общей проблемы нефтяной и газовой промышленности проходит через три этапа:

1. Изучение факторов и условий, влияющих на проблему;

2. Разработка теоретического решения проблемы;

3. Практическое решение проблемы и технико-экономическая оценка результатов. 
Увеличение экономической эффективности поисковых и разведочных работ считается одной из сторон общей экономической проблемы нефтяной и газовой промышленности. Другими сторонами этой проблемы являются следующие:

- Увеличение отдачи основных производственных фондов;

- Увеличение эффективности капитальных вложений;

- Увеличение эффективности использования трудовых ресурсов, производственных средств (1).

Несмотря на длительную историю добычи нефти и газа в Азербайджане, специалисты высоко оценивают недра республики с точки зрения перспективности на нефть и газ, высказываются о богатых запасах углеводородов.

Общая площадь территории Азербайджана на суше и в азербайджанском секторе Каспийского моря, представляющая интерес с точки зрения нефтеносности, составляет 100 тыс.км² $^{2}$ общая площадь с выявленной нефтегазоносностью и оцененными прогнозными запасами составляет 70 тыс.км ${ }^{2}$, в том числе более 20 тыс.км ${ }^{2}$ на соединенной шельфовой акватории.

Перспективные нефтегазоносные участки и наиболее близкие к перспективным составляют приблизительно 17 тыс.км².Установлено, что малоизученная в геологическим отношении с невыясненной нефтегазоносностью площадь охватывает территорию 13 тыс.км².

Сегодня и на суше Азербайджана возможно повышение добычи нефти как за счет применения современных методов интенсификации по старым месторождениям, так и открытия новых месторождений. Отметим, что средний плиоцен, миоцен-олигоцен и очень глубокие отложения мезозоя в условиях суши Азербайджана изучены недостаточно. На площади более, чем $30 \%$ территории республики, возможности поиска и разведки литологических и стратиграфических неструктурных резервуаров в достаточной степени не оценены, в то время как они являются важными источниками и направлениями увеличения запасов углеводородов. Имеется большая потребность в правильном выборе новых методов и технологий, в уточнении геологического строения, определении точек заложения разведочных скважин, испытании и эксплуатации скважин в сложных горно-геологических условиях.

Площадь акватории Каспийского моря, составляющая 379 тыс.км², представляет собой редкий внутриконтинентальный бассейн, в пределах которого геолого-геофизическими методами открыты 386 антиклинальных поднятий и перспективных структур. Можно констатировать, что половина начальных потенциальных запасов нефти Азербайджанской Республики сосредоточена в шельфовой зоне Азербайджанской структуры Каспийского моря и только $34 \%$ их разведано геолого-геофизическими методами.

Наиболее изученным в Каспийском море является азербайджанский сектор. Здесь выявлены 145 перспективных структур, в том числе при глубине моря до 60 - 40 м структур, при глубине 60-200 м - 33 структуры, при глубине выше 200 м - 72 структуры. Увеличению потока инвестиций способствует изменение условий инвестирования в Азербайджанской Республике - повышение надежности страны, уменьшение интегрального показателя уровня политического и экономического риска для инвестора. На современном этапе развития экономики важнейшее значение приобретает проблема рационального использования нефтяных ресурсов. К основным факторам рационального использования нефтяных ресурсов относятся следующие:

- Оптимизация масштабов и географического размещения нефтяной промышленности; 
- Выбор рациональных систем разработки новых месторождений и установление оптимальной очередности ввода их в эксплуатацию;

- Широкое внедрение новых методов увеличения нефтеотдачи пластов и других мероприятий, повышающих эффективность использования нефтяных ресурсов на разрабатываемых объектах;

- Расширение и совершенствование минерально-сырьевой базы развития отрасли на перспективу;

Коренное улучшение природоохранной деятельности отрасли на основе создания и широкого внедрения малоотходных и безотходных технологий.

В настоящее время в нефтяной промышленности выполняется комплексная программа работ по увеличению нефтеотдачи пластов, рассчитанная на длительную перспективу. Необходимость осуществления этой программы диктуется тем, что несмотря на увеличение конечной нефтеотдачи пластов, достигнутой благодаря широкому внедрению методов заводнения, в недрах разрабатываемых месторождений остается более половины запасов нефти.

Извлечение хотя бы части остаточных запасов имеет важное значение в связи со вступлением многих месторождений в позднюю стадию разработки, а также осложнением поисков и разведки нефти, удорожанием бурения и добычи нефти при переходе к эксплуатации месторождений на больших глубинах.

Одним из базовых факторов, предопределяющих нефтяную политику той или иной страны, являются, как известно, запасы нефти. Запасы нефти являются фундаментом всех возможных инвестиций. При этом важным обстоятельством является то, чтобы эти запасы располагались в климатически и географически благоприятных условиях, чем выгодно отличается Азербайджан. Как видно из рисунка 1, Азербайджан выглядит довольно убедительно: его запасы равны запасам стран Юго-Восточной Азии, Австралии и стран Океании вместе взятых, и почти вдвое превышают запасы Западной Европы. Запасы Северной Америки превышают запасы Азербайджана почти в три с половиной раза. Однако при этом не надо забывать, что на поисковые работы в Северной Америке вложены огромные средства. Вопрос, куда меньше всего вложены средства на поисковые работы в этом ряду, должен решаться между Россией и Азербайджаном.

Основной производной запасов нефти является ее добыча. Она характеризует как политико-экономическое, так и техническое состояние той или иной страны. Политическая и экономическая стабильность, особенно. В развивающихся странах, во многом зависит от нефтедобычи в стране.

Автор исследования (1), используя данные, а также, зная величину территорий соответствующих стран, определил добычу нефти надушу населения. По мнению автора исследования полученные значения условно характеризуют «нефтяное богатство страны». Следует заметить, что по объему добычи нефти на душу населения в начале двадцатого столетия Азербайджан среди нефтеносных регионов мира занимал первое место.

Сравнивая темпы экономического развития нефтедобывающей промышленности Азербайджана в период 1901-1930гг. с темпами развития других известных нефтеносных регионов мира, следует отметить опережающую тенденцию роста объема добычи нефти США, которая возросла за рассматриваемый период более, чем в 13 раз, тогда как Азербайджан обеспечил рост добычи нефти за соответствующий период всего лишь на 3,2 млн.тонн. 

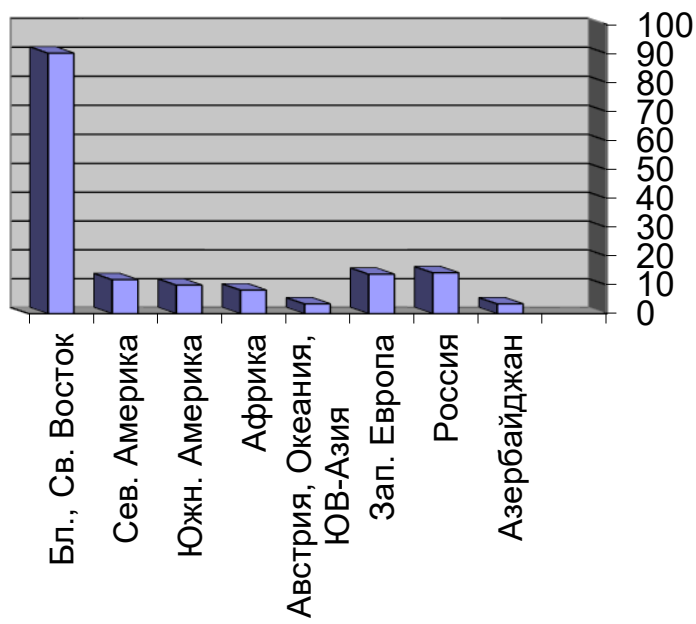

\begin{tabular}{|c|c|c|c|c|c|c|c|c|}
\hline & 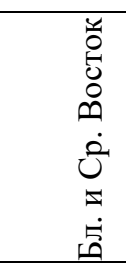 & 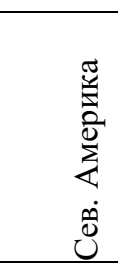 & 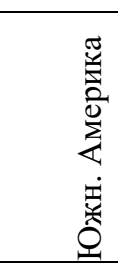 & 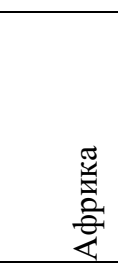 & 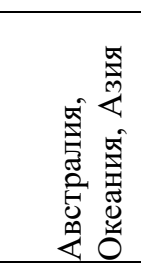 & 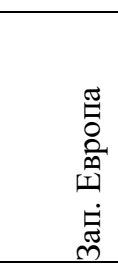 & 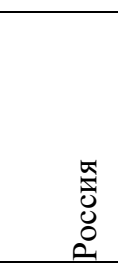 & 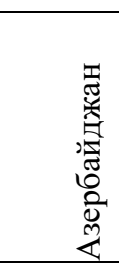 \\
\hline $\begin{array}{l}\text { Запасы } \\
\text { млрд.т. }\end{array}$ & 90,1 & 11,8 & 9,9 & 8,2 & 3,4 & 13,7 & 14,2 & 3,4 \\
\hline
\end{tabular}

Рисунок 1. Запасы нефти по регионам мира

Азербайджан по уровню ежегодной добычи нефти, приходящейся на душу населения, значительно опережает многие страны. В их числе которых можно назвать Аргентину, Бразилию, Венесуэлу, Египет, Индию, Индонезию, Иран, Китай, Перу, Румынию, Сирию, Тунис и Туркменистан. Следует заметить, что при столь опережающей добыче нефти, Азербайджан значительно уступает своей численностью населения при сравнении с этими странами, где исключением служат только лишь Туркменистан.

Общеизвестно, что уровень показателей деятельности нефтедобывающей промышленности зависит и от природных условий. Необходимым условием для определения роли Азербайджана в мировом нефтяном бизнесе, является уточнение объема балансовых и извлекаемых запасов нефти.

Чтобы внести окончательную ясность в этот вопрос, нами проанализирована мировая конъюнктура нефтедобычи при различных запасах.

С этой целью, используя данные по запасам, добыче нефти и количеству эксплуатационных скважин по 71 нефтедобывающим странам мира, таких как США, Мексика, Канада, Англия, Норвегия, Саудовская Аравия, Кувейт, Йемен, Венесуэла, Нигерия, Греция, Испания, Бенин и др., разработана математическая модель, характеризующая мировую конъюнктуру в добыче нефти в зависимости от запасов и количества скважин. Разработанная модель имеет вид:

$\mathrm{Q}_{\text {доб.млн.т. }}=0,00859 \mathrm{~V}_{\text {зап.млн.т. }}+0,00062 \mathrm{~N}_{\text {скв. }}$

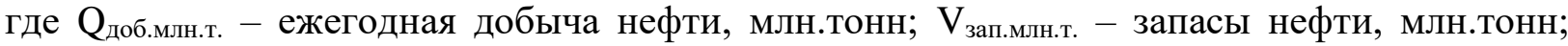
$\mathrm{N}_{\text {скв. }}$ - общее количество скважин. 
Используя разработанную математическую модель и подставив соответствующие значения по Азербайджану, получим ежегодную добычу нефти в 16 млн.тонн. Эта величина характеризует добычу нефти в Азербайджане в свете мировой тенденции в нефтедобыче. Естественно, в различных условиях, особенно экстремальных, эта величина может быть значительно увеличена. Она интересна тем, что может служить отправной точкой для принятия решения (3).

В связи с этим необходимо отметить, что в военные сороковые годы, когда страна находилась в экстремальных условиях, если условно соотнести разработанную модель к тем временам, то реальная добыча нефти в 5 раз превышала допустимо расчетную: 22 млн. тонн нефти против 4 млн.тонн. А если можно было бы использовать модель тех лет, то можно предположить, что добыча тех лет превышала мировую конъюнктура в десятки раз. В связи с изложенным, увеличение ежегодной добычи в 2-3 раза относительно уровня, характеризующего мировую конъюнктура вполне соотносится с настоящим временем. Но надо при этом учитывать, что в бывшем СССР при количестве скважин, более чем в 4 раза меньшем, чем в США, добывалось нефти больше в результате широкого внедрения заводнения, а также целого ряда не инженерных методов. В результате в среднем на 1 тонну нефти попутно добывалось 13 тонн воды. При такой стратегии нефтедобычи и переходе на международные цены доходы от добытой нефти вплотную приблизились к расходам.

Основным фактором, характеризующим процесс нефтеизвлечения, является ее динамика. Необходимым дополнением при описании этого процесса является учет эффективности современного нефтедобывающего оборудования и оптимальных методов разработки морских нефтяных месторождений. В начале приведем несколько наиболее важных фактов, характеризующих морскую нефтедобычу. Поиском и добычей нефти и газа на акваториях занимаются в 45 странах мира, которые ежегодно вкладывают более 50 млрд.долларов. В настоящее время открыто более 2000 морских месторождений с суммарными запасами около 40 млрд.тонн нефти и почти 35 триллионов куб.м газа, что составляет около 25\% предполагаемых запасов на шельфе морей и океанов. На долю Мексиканского залива, Персидского залива и Северного моря приходится 75\% мировой добычи в море и $85 \%$ газа. Лишь в Норвегии за счет ввода в разработку новых крупных нефтяных месторождений добыча имеет стабильный характер.

Несмотря на огромные затраты на обустройство морских месторождений, значительным экономическим риском, связанным с их вводом в эксплуатацию, истощением в настоящее время основных морских месторождений и неблагоприятными условиями для финансирования работ по поиску и освоению новых запасов, морская добыча продолжает оставаться высокорентабельной отраслью. Соотношение запасов, добычи и переработки нефти по сравнению с высокоразвитыми странами мира (кроме ближнего и среднего Востока) указывает на большое будущее Азербайджана.

Мировой баланс нефти по странам, а именно, накопленная добыча нефти, также открытые и неоткрытые запасы, приведены на рисунке 2.

Как видно из рис.2, и с этих позиций у Азербайджана большое будущее при наличии инвестиций. Картина становится еще более рельефной, если проанализировать отношение добычи к текущим и неоткрытым запасам нефти (смотри на рис.3.). 

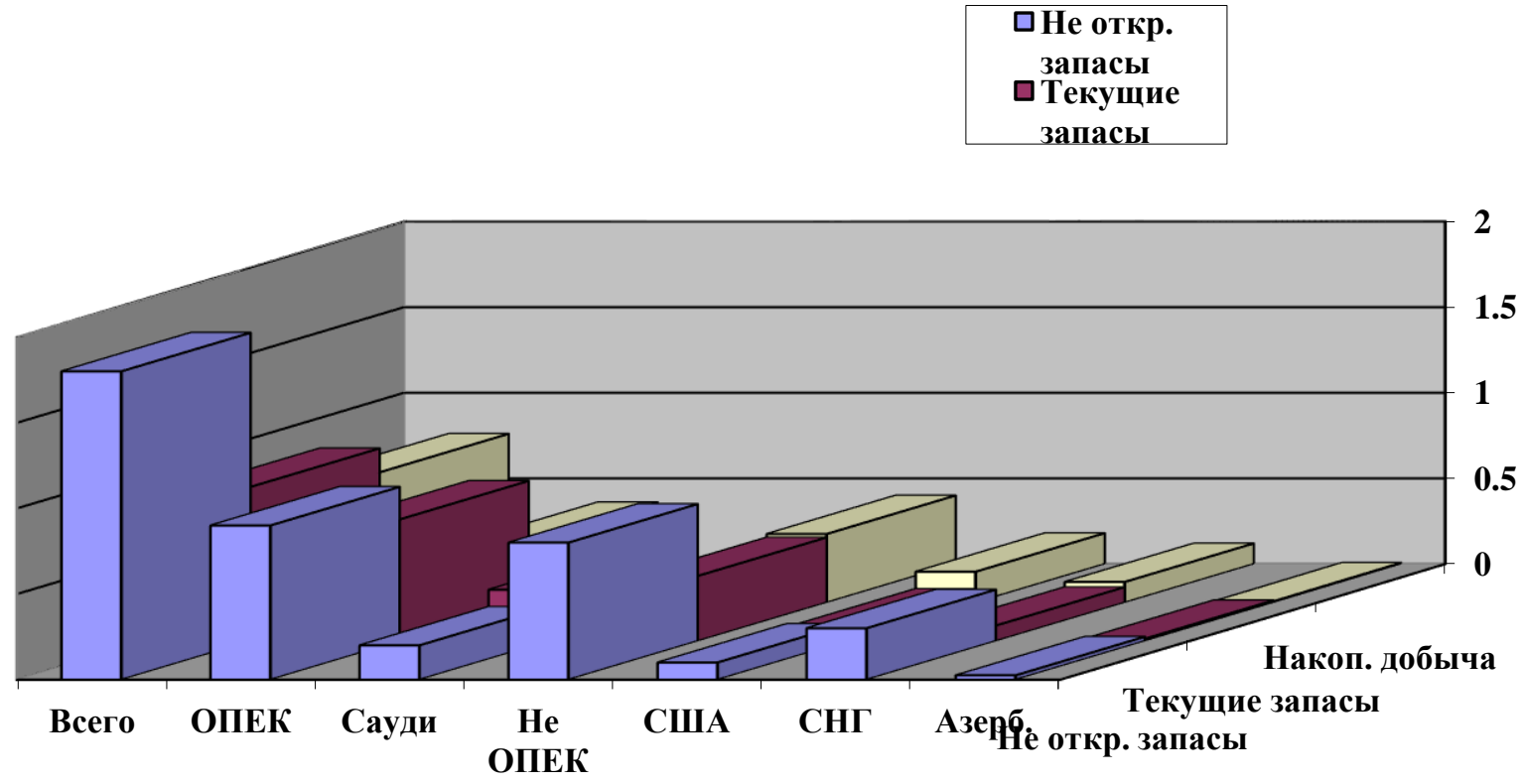

\begin{tabular}{|l|l|l|l|l|l|l|l|}
\hline & Всего & ОПЕК & Сауди & Не ОПЕК & США & СНГ & Азерб. \\
\hline $\begin{array}{l}\text { Не откр. } \\
\text { запасы }\end{array}$ & 1,8 & 0,9 & 0,2 & 0,8 & 0,1 & 0,3 & 0,025 \\
\hline $\begin{array}{l}\text { Текущие } \\
\text { запасы }\end{array}$ & 0,9 & 0,71 & 0,3 & 0,38 & 0,08 & 0,09 & 0,013 \\
\hline $\begin{array}{l}\text { Накоп. } \\
\text { добыча }\end{array}$ & 0,76 & 0,36 & 0,11 & 0,4 & 0,18 & 0,12 & 0,007 \\
\hline
\end{tabular}

Рисунок 2. Мировой баланс нефти (млрд. баррелей)

Эти коэффициенты во многом характеризуют нефтяное будущее той или иной страны. Как известно, накопленная добыча нефти и запасы нефти находятся в следующем соотношении: чем меньше накопленная добыча и больше запасы нефти, тем больше перспектив у страны. Естественно, в абсолютном исчислении эти величины должны быть значительными (4). Как видно из рис.3, позиции Азербайджана весьма убедительны. Имея коэффициент 0,53 по отношению к открытым запасам и 0,28 по отношению к неоткрытым, Азербайджан практически превосходит все страны мира. Имея равный коэффициент по текущим запасам с ОПЕК и уступая лишь Саудовской Аравии, он намного опережает США, позиции которых просто катастрофически. 


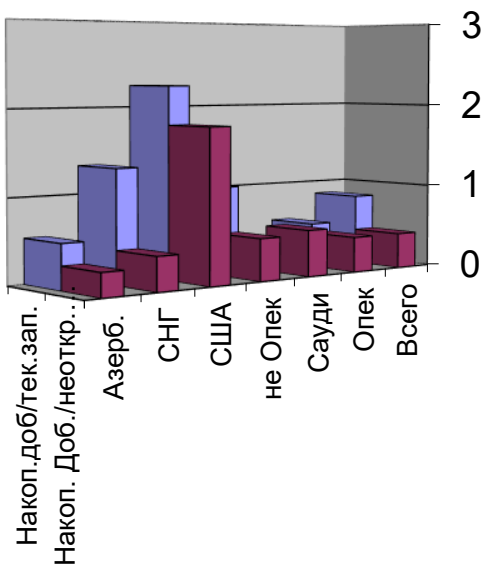

口Накоп.доб/тек.зап.

口Накоп. Доб./неоткр. Запасы

\begin{tabular}{|l|l|l|l|l|l|l|c|}
\hline & Всего & ОПЕК & $\begin{array}{l}\text { Сауд } \\
\text { и }\end{array}$ & $\begin{array}{l}\text { Не } \\
\text { ОПЕК }\end{array}$ & США & СНГ & Азербайджан \\
\hline Накоп.доб/тек.зап & 0,84 & 0,53 & 0,37 & 1,05 & 2,25 & 1,33 & 0,53 \\
\hline $\begin{array}{l}\text { Накоп.доб.неоткр.зап } \\
\text { асы }\end{array}$ & 0,42 & 0,42 & 0,55 & 0,5 & 1,8 & 0,4 & 0,28 \\
\hline
\end{tabular}

Рисунок 3. Коэффициенты перспективности мировой нефтяной индустрии

Заключение. Следует сказать и о том, что основной производственный потенциал республики должен быть мобилизирован на развитие приоритетных стратегических сфер деятельности, в целях установления, в перспективе, полной устойчивости в экономике республики. Нельзя не отметить и то, что важнейшей причиной, определившей в первые стартовые годы перехода к рыночной экономике всеобщий спад производства явилась неспособность соответствующих органов управления экономикой и в том числе нефтедобывающей промышленности принимать стратегические решения. Без внимания остались некоторые приоритетные сферы развития, о чем свидетельствуют показатели в структуру экспорта, наличие значительных объемов, вывозимых ресурсов нефти и нефтепродуктов, тогда как мощности нефтеперерабатывающих заводов республики остаются все еще недогруженными.

\section{ЛИТЕРАТУРА}

1. Мирзаджанзаде А.Х., Султанов Ч.А. Этюды нефтяной концепции Азербайджана. Баку, 1994, -100 стр.

2. Сафаров Г.А. Эффективность использования основных фондов в нефтегазодобыче. Баку, изд.“Текнур" - 2014, 332 стр.

3. Мирзаджанзаде А.Х., Алиев Н.А., Юсифзаде Х.Б. и др. Фрагменты разработки морских нефтегазовых месторождений. Баку: Элм, 1997, -408 с.

4. Рохлин С.М., Рыженков И.И., Фетисов А.А. Экономика рационального использования нефтяных ресурсов недр. М.: Недра, 1991, -236 стр. 


\title{
WAYS TO INCREASE THE EFFICIENCY OF USE OF OIL RESOURCES
}

\section{Arzu Mirqeydarova}

Azerbaijan State Oil and Industry University, Azerbaijan.

\begin{abstract}
This article talks about the current state of the oil fields of the Republic of Azerbaijan. Information is given on the development of oil fields in Azerbaijan, which are at a late stage of development. A mathematical model is presented that characterizes the world oil production situation depending on reserves and the number of wells. A comprehensive systematic analysis is carried out for the SOCAR fields as a whole, after which the reasons for the deterioration of the main technical and economic indicators are identified and measures are proposed to identify reserves and factors for improving these indicators.
\end{abstract}

Ключевые слова: oil production, economic efficiency, late stage of development, oil reserves 


\title{
ЛЕЧЕБНО-ОЗДОРОВИТЕЛЬНЫЙ ТУРИЗМ И ПЕРСПЕКТИВЫ ЕГО РАЗВИТИЯ В ГРУЗИИ
}

\section{Вахтанг Микашавидзе}

Ассоциированный профессор, Государственный университет имени Шота Руставели, Батуми, Грузия. Email: mikashavidze.vakhtang@bsu.edu.ge

\section{РЕЗЮМЕ}

В статье на основании анализа деятельности туристической индустрии в Грузии установлено, что несмотря на систематичный рост числа визитеров в нашей стране за последние годы, хотя доходы от туризма выросли, но средние затраты одного визитера увеличились только незначительно, тем не менее, все еще значительно отстает от среднего глобального показателя и оказывает относительно небольшое влияние на социально-экономическое развитие страны.

На основе экономико-статистический материалов и социологических исследовании, в статье проанализирована современное состояние развития лечебно-оздоровитебльного туризма в Грузии, указаны на все еще существующие недостатки и нерешенные проблемы, установлены реальные пути для их решения. Разработаны и обоснованы комплексные вопросы резкого роста доходов от туризма. В частности, восстановление и развитие бальнео и бальнеоклиматических курортов на основе природных ресурсов страны и строительство новых медицинских центров. Внедрение на практике современных лечебно-оздоровительных методов, обеспечение пациентов обслуживанием SPA и Wellness процедурами. На высоком уровне прием, лечение-реабилитация и др. для пациентов с постковидным синдромом. Это сделает возможным привлечение с разных стран мира значительного потока визитеров, в том числе высоко платежеспособных. Полное задействование данных мер дает основание для оптимизма в успешном развитии лечебно-оздоровительного туризма.

Ключевые слова: Грузия; Туризм; Индустрия; Курорты; Лечебно-оздоровительный; бальнеоклиматический; SPA; Wellness;

\begin{abstract}
The article, based on the analysis of the activities of the Georgian tourism industry, states that despite the systematic increase in the number of visitors to our country in recent years, revenues from tourism have indeed increased, but the average cost per visitor has only slightly increased; However, the global average is still significantly lower and has a relatively small impact on the socio-economic development of the country.

The paper analyzes the current state of development of medical tourism in Georgia on the basis of economic-statistical materials and sociological research. It also shows the still existing shortcomings and unresolved problems in this area, identified real ways to solve it. Complex issues of sharp growth in tourism revenues have been developed and substantiated. In particular, the restoration and development of balneo and balneo-climatic resorts based on the natural resources of the country and the construction of new medical centers, introduction and implementing of modern healing methods in practice, provision of services to patients with spa and wellness procedures. Admission, treatment-rehabilitation, etc. to high standards for patients
\end{abstract}


with post-covid syndrome. This will make it possible to attract a significant influx of visitors from around the world, including the high-paying ones. The full implementation of these measures provides the basis for optimism for the successful development of health tourism.

Keywords: Georgia; Tourism; Industry; Resorts; Medical and recreational; balneoclimatic; SPA; Wellness;

Введение: Медицинский, лечебно-оздоровительный туризм является сравнительно новым, но быстро развивающимся направлением глобальной системы здравоохранения. За последние годы во многих странах мира систематически растет число пациентов заинтересованных этим сегментом туризма, также резко растет полученный от них доход. Такие страны, как Израиль, Турция, Швейцария, Италия, Индия, Индонезия и другие, ежегодно получают доходы в миллиарды долларов от лечебно-оздоровительного туризма основанного на SPA и Wellness процедур. Исходя из выше сказанного для Грузии крайне важно перенять опыт этих стран. С этой стороны за последний период особое внимание было уделено на вопросы реставрации-реконструкции лечебно-медицинских учреждений знаменитых в нашей стране бальнеологических и бальнеоклиматических курортов, таких как Цкалтубо, Боржоми, Саирме, Тбилиси, Абастумани и других. В настоящее время в лечебно-оздоровительных учреждениях Грузии внедрено обслуживание пациентов SPA и Wellness медицинскими процедурами, что повлияло на увеличение потока туристов и на рост дохода от туризма. В условиях современной пандемии еще более важным стало обеспечение ускоренного развития лечебно-оздоровительного туризма. Лечебнооздоровительные центры страны должны быть заранее подготовлены должным образом, чтобы принимать, лечить и обслуживать в соответствии с высокими стандартами миллионы посетителей с изнурительным постковидныйм синдромом. При этом в короткие сроки можно добиться увеличения роста темпов доходов в туристическом секторе и восстановить туристический потенциал. Такая траектория развития индустрии туризма является предпосылкой для преодоления сложностей, созданных в секторе, и превращения кризиса в новую возможность.

Несмотря на многочисленных проблем, которые все еще существуют в туристической индустрии Грузии, можно сказать что он стоит на необратимом пути успешного развития. На это указывают осуществление весьма солидных инвестиции в этой сфере за последние годы, и создание за их счет новых или обновленных и модернизированных лечебнооздоровительных объектов и полностью курортов. В пример этому можно привести Коджорский медицинский велнес курорт «BIOLI», реконструированный «Tskaltubo Spa Resort», обновленные курорты Саирме и Абастумани, курорт Шекветили с недавно открытым местом размещения премиум класса Paragraph Resort \& Spa и другие.

В современном мире туризм приобрел глобальный масштаб и значение. Повышение уровня жизни, продолжающиеся процессы демократизации и экономической стабилизации создали необходимые условия для того, чтобы туризм стал массовым и глобальным событием. В настоящее время, индустрия туризма является одним из крупнейших, высокодоходных и динамично развивающихся секторов в мире, она играет важную роль в развитии экономики многих стран, в том числе Грузии. Несмотря на накопившееся в нашей стране множество проблем (политических, социальноэкономических, демографических и др.) туризм, всё равно интенсивно развивался. Так например, в 2019 году количество международных визитёров достигло 7725774, в том числе, количество иностранных туристов - 5080478, что на 7,3 и 6,8 процента больше по сравнению с аналогичным показателем прошлого года [1]. K сожалению, в 2020 году развитию туризма Грузии, под угрозой поставила новая пандемия коронавируса в мире. В 
частности, в 2020 году, количество международных посетителей составило 1513421, а количество иностранных туристов - 1087093 человека (Источник: Министерство внутренних дел Грузии, информационно-аналитическое управление), что на 80,4\% и 78,6\% меньше, чем за аналогичный период прошлого года.

Изучение современных тенденций развития туристической индустрии Грузии убедило нас в том, что для решения задач, стоящих перед страной, необходимо значительно увеличить доходы от туризма. Правда, в последние годы, доходы от туризма в стране увеличились, но средние расходы на одного посетителя увеличились лишь незначительно, хотя от глобальных показателей по-прежнему значительно отстают. Таким образом, расходы на международных посетителей имеют относительно небольшое влияние на социальноэкономическое развитие страны [2]. Следовательно, с целью получения больше доходов от туризма, необходимо найти еще не использованный потенциал в этом секторе, который пользуется большим спросом на международном уровне, и в то же время может привлечь относительно высокооплачиваемых посетителей. Одним из таких сегментов туризма, в настоящее время, считается медицинский туризм.

Литературный обзор. Теоретической основой этой статьи является официальный документ национальной администрации туризма Грузии - Стратегия туризма Грузии до 2025 года [2], который направлен на содействие устойчивому развитию туризма, увеличение доходов и повышение важности этого сектора. Кроме того, в статье используются концептуальные мнения зарубежных авторов, опубликованные в научных сборниках западных стран, по проблемам туризма в целом и развития медицинского и оздоровительного туризма в частности [3; 5].

В статье широко использованы работы профессоров университетов Грузии и сотрудников научно-исследовательских институтов. В научной статье - Медицинский туризм и Грузия: специфика проблем и рекомендации - кратко обозрены развитие медицинского и лечебнооздоровительного туризма в мире и в Грузии, Верулава Т., [4]. В исследовании инновационное развитие оздоровительного туризма на примере энотерапии и ампелотерапии в Грузии, кратко рассмотрены перспективы развития туризма в Грузии и в мире, Гогуадзе Н,. Хускивадзе М., [6]. В статье преимущества Грузии в лечебном туризме, рассмотрены большие возможности Грузии в области оздоровительного туризма и показаны еще неиспользованные ресурсы, Кутателадзе Р., Курашвили Г., Беридзе Т., [7]. В статье медицинский туризм, как продукт устойчивого развития, показана важность развития оздоровительного туризма в условиях резкого увеличения доходов от туризма, Пиранашвили М., Гамсахурдиа Т., [8]. В исследовании перспективы развития кластеризации медицинского и SPA туризма (на примере Цхалтубо), широко рассмотрено значение бальнеотерапевтического лечения Цхалтубо, пути его восстановления и развития, Надареишвили Н., Дзидзикашвили Н., [9]. В монографии о туристических ресурсах Грузии подробно рассматривается современное состояние природнорекреационных ресурсов Грузии и показаны реалистичные пути их развития, Микашавидзе В., Микашавидзе Ж., [14] и других. В качестве информационной базы данного исследования использовались официальные данные статистики, а также собственные результаты исследования автора статьи.

Цель исследования. Целью статьи являются исследование текущего состояния развития лечебно-оздоровительного туризма в Грузии на основе экономико-статистических и других методов анализа, также показать существующие проблемы в этой области и 
определить пути их успешного решения. Разработать и обосновать вопросы резкого роста доходов от туризма.

Результаты. Медицинский туризм является относительно новым, но быстро развивающимся направлением. Главное здесь то, что темпы его роста самые высокие среди других сегментов туризма. Также, его растущее значение подтверждается тем, что более 50 стран мира подняли развитие медицинского туризма на уровне государственной политики [3]. Это концепция современного здоровья, основанная на медицинском туризме, суть которой заключается в том, что когда пациент не может решить проблему со здоровьем в своей стране, он выбирает желаемую страну, врача, клинику, где ему предложат самое современное лечебно-диагностические методы по доступной цене. В свою очередь, в условиях экономической конкуренции, медицинский туризм способствует более быстрому развитию медицины и может значительно изменить национальную систему здравоохранения [4]. Следует отметить, что медицинский туризм включает в себе лечение, хирургические услуги пациентов, а также лечение на лечебных курортах, реабилитацию и оздоровление. Здесь, мы будем говорить только об этом последнем сегменте медицинского туризма. В этой связи, интересно посмотреть, какой потенциал имеет Грузия с точки зрения лечебно-оздоровительного туризма, есть ли на него спрос, насколько он интересен с точки зрения получения доходов и каковы перспективы полной реализации этого потенциала.

По всему миру, за последние 10-15 лет, замечается усиление интереса населения к лечебно-оздоровительному туризму, популярность которого растет из года в год. В 2018 году, туристические расходы на лечебно-оздоровительный туризм составили 4,5 триллиона долларов, этот показатель, с 2015 по 2017 год, ежегодно увеличивался на 6,5\%, что в два раза быстрый рост по сравнению с туризмом. Однако, следует отметить, что на лечебно-оздоровительный туризм, международные туристы тратят в среднем 1,528 долларов США за поездку, что на 53\% больше, чем средние расходы международных туристов [5].

Основываясь на опыте передовых туристических стран, можно смело сказать, что в такой стране, богатой природными и курортными факторами, как Грузия, имеющая 103 курорта и 168 курортных мест, целесообразно и приоритетно ускорить развитие лечебнооздоровительный туризм, исследовать новые рынки и поднять конкурентоспособность Грузии, как международного туристического бренда. Это возможно благодаря созданию и предложению таких инновационных продуктов, как услуги SPA и Wellness. B сегодняшней промышленной среде, ускоренного темпа жизни, в обстановке экологических катастроф и этноконфликтов, человек оказался в особо стрессовой ситуации, к чему добавляется пост-ковидный период и связанные с этим проблемы со здоровьем. В таких условиях, большой спрос на такой инновационный туристический продукт, где сочетаются отдых, релаксация, развлечения, восстановление физического и духовного равновесия, познание нового, лечение и оздоровление [6]. Таким туристическим продуктом признан SPA и Wellness туризм.

В сфере медицинского туризма преобладают оздоровительный и SPA туризм (41\% рынка). Развитие медицинского туризма обусловлено качеством, доступностью и ценой различных медицинских услуг в разных странах [4]. Например, цены на медицинские и оздоровительные услуги в Грузии, намного дешевле, чем в продвинутых странах запада, что ставит ее в выгодное положение. В таких условиях, он может привлечь туристов названного сегмента, как из соседних стран, так из более отдаленных стран и добиваться 
успеха в конкурентной борьбе, предоставляя услуги пациентов в соответствии с международными стандартами. Растущий спрос на оздоровительный туризм в мире связан с неуклонным увеличением количества пользователей классических SPA процедур. В то же время, доходы от этой индустрии постепенно увеличиваются, и она является важным источником занятости во всем мире [7].

В настоящее время спрос на SPA и Wellness курортов в мире систематически растёт. Примерами этого являются Израиль, Турция, Италия, Швейцария, Индия, Индонезия, Карибский бассейн и другие страны, которые ежегодно получают миллиарды долларов дохода, от лечебно-оздоровительного туризма, на основе SPA и оздоровительных процедур. Следует отметить, что принятый правительством нашей страны документ «Стратегия туризма Грузии - 2025» предусматривает устойчивое развитие туризма, увеличение доходов и повышение значимости отрасли. Поэтому, особое внимание заслуживает обмен опытом вышеперечисленных стран, приобретение современных технологий в области лечения и оздоровления и внедрение передовых стандартов в медицинских учреждениях таких известных бальнеологических и бальнеоклиматических курортов, как Цхалтубо, Боржоми, Саирме, Тбилиси, Абастумани, Уцера, Ахтала и др. При этом, уже несколько лет идет интенсивный процесс реставрации-реконструкции действующих медицинских учреждений и строительства новых.

Особое место среди бальнеотерапевтических средств Грузии занимают термальные радиоактивные газированные воды курорта Цхалтубо, которые далеко славятся своим лечебным действием. Важной особенностью этих минеральных вод является изотермия (способность поддерживать равномерную температуру). Температура близка $\left(32-35^{\circ} \mathrm{C}\right) \mathrm{\kappa}$ температуре человеческого тела, что позволяет использовать его в виде ванн без нагрева и охлаждения. Высокоэффективное лечебно-профилактическое действие минеральных вод обусловлено их сложным составом и своеобразным сочетанием основных компонентов, аналогов которым нет даже за рубежом. Минеральная вода лечит следующие заболевания: ревматизм, заболевания суставов и периферической нервной системы, сердца и сосудов, кожи, нарушения обмена веществ, нарушения эндокринной системы и многие другие заболевания [9].

Цхалтубо, с точки зрения банльеотерапии, курорт международного значения, которая выделяется редким микроклиматом, зеленью и особым гидрологическим строением. Здесь, релаксация с лечебной термальной водой и проведение лечебных процедур возможны в любое время года, что создает уникальную возможность для развития лечебно-оздоровительного туризма. Главной достопримечательностью курорта является лечебно-оздоровительный комплекс «Бальнеокурорт Цхалтубо», который с 1892 года принимает иностранных и местных отдыхающих. Городу, с 1920 года предоставили статус бальнеологического курорта и не мог вместить поток туристов до 90-х годов прошлого века. Восстановление и освоение отрасли началось в начале нынешнего века и продолжается по сей день. Следует отметить, что в 2018 году Цхалтубо, как бальнеологический курорт, стал членом Ассоциации исторических термальных городов, а в 2019 году «Бальнеокурорт Цхалтубо» был признан аффилированным членом всемирной туристской организации ОOH (NUWTO).

Сегодня, в Цхалтубском муниципалитете функционируют несколько гостиниц, недавно отреставрированные санатории, «Спа резорт» и пансионат «Цхалтубо», а также 4 ванных комплекса, отвечающие современным стандартам. В результате, в 2018 году, в Цхалтубо было принято и размещено 315 тысяч посетителей, а в 2019 году - 339 тысяч. Правда, 
такая динамика роста туризма является многообещающей, но она всё еще не соответствует потенциалу туристической индустрии муниципалитета Цхалтубо. На сегодняшний день, курорт может принимать всего 1000 пациентов с бальнеологическим назначением, что в 2,5 раза отстаёт от показателя 90-х годах прошлого века.

В настоящее время основной стратегической задачей муниципалитета Цхалтубо является строительство новой инфраструктуры на территории курорта, восстановление старой и развитие различных услуг. Особое внимание следует уделить разведению ВПЛ (внутренне перемещённые лица) из всех существующих санаториев и обеспечению их новым жильем [10]. Новые гостиницы и санатории должны соответствовать высоким европейским стандартам. Таким же стандартам должны соответствовать недавно отреставрированные и обновленные санатории, которые в то время были достаточно комфортабельными и с архитектурной точки зрения являются историческим и культурным наследием. В то же время, в ускорении развития туризма в муниципалитете Цхалтубо, приоритетную роль должен сыграть лечебно-оздоровительный туризм, в основе которого лежат SPA и Wellness услуги. Это будет способствовать - развитию новых рынков и повышению международной конкурентоспособности Грузии в сфере туризма, привлечению высокооплачиваемых посетителей и резкому увеличению доходов от туризма. Мы твердо верим, что при правильном управлении, бальнеологический курорт Цхалтубо может быстро стать визитной карточкой всей Грузии.

Боржоми один из важнейших бальнеологических курортов Грузии. Лечебные свойства минеральных вод вулканичесского происхождения известны с давних времен. Он на протяжении многих лет пользовался большой популярностью в Российской Империи, на территории бывшего Советского Союза и за его пределами. Сегодня, минеральную воду Боржоми вывозят во многих странах мира. Среди заболеваний, показанных для лечения на курорте, основное место занимают органы пищеварительной системы, особенно болезни желудка и кишечника. Вода Боржоми успешно применяется для лечения заболеваний печени и желчевыводящих путей, эндокринной системы, сердечнососудистой системы и других. Кроме того, доказано успокаивающее действие водных ванн Боржоми при функциональных заболеваниях нервной системы. Минеральную воду Боржоми назначают для промывания желудка и кишечника, также её используют для лечебных прогулок и т. д.

В последние годы, индустрия туризма в муниципалитете Боржоми интенсивно развивается, следовательно, количество иностранных посетителей также увеличивалось. В частности, в 2018 г., их количество увеличилось до 303 тыс. человек, что почти вдвое больше, чем в 2015 г. [11].

Саирме является одним из важных бальнеологических курортов Грузии. Минеральные воды Саирме стали известными с конца XIX века. Они относятся к углекислым, гидрокарбонатным, кальциево-натриевым (первые и третие источники) и угольнокислотным гидрокарбонатным, натриевым водам типа Боржоми (четвертые и пятые источники). Углекислотные воды Саирме особенно полезны при заболеваниях почек и мочевыводящих путей, что определило урологический профиль курорта. Кроме того, здесь проходят лечение пациент с заболеваниями печени, желчевыводящих путей и желудочно-кишечного тракта. А также нарушения обмена веществ. Кроме того, минеральную воду разливают в бутылках под названием «Саирме» и её реализация производится, как на местных, так и на международных рынках. 
На курорте Саирме вытыкаются четыре различных лечебных источника и один термальный источник. После реконструкции нового курорта «Саирме», в составе комплекса представлены три гостиницы, две из которых четырехзвездочные. В комплексе 342 номера, в которых единовременно могут разместиться до 1000 посетителей. Комплекс включает в себе современных пищевых и медицинских объектов, лечебный/релаксационни SPA и Wellness центр оснащённым немецкими оборудованиями, а также различные мероприятия. Курорт Саирме принимает посетителей на все четыре сезона года [12]. К 2020 году курорт «Саирме» стал победителем World Travel Award и получил награду «Ведущий курорт Грузии 2020».

Абастумани известный горноклиматический и бальнеологический курорт, расположен в муниципалитете Адигени. Основным лечебным фактором курорта является горный климат, годовая сумма солнечной радиации достигает до 2000 часов. Среднегодовая температура воздуха составляет $+6,5^{\circ} \mathrm{C}$, а июля $+17,3^{\circ} \mathrm{C}$. В связи с тем, что Абастумани защищен от прямого воздействия влажных атмосферных морских течений, количество осадков относительно невелико и составляет в среднем 620 мм в год. Курорт Абастумани, помимо своего климата, издавна славится своими хлор-сульфатно-натриевыми минеральными водами, температура которых $+39^{\circ} \mathrm{C}-+48^{\circ} \mathrm{C}$. Минеральная вода используется в виде ванн для опорно-двигательного аппарата (суставы, мышцы, периферическая система и т.д.), а также при хронических гинекологических заболеваниях. Абастумани специализируется в основном на лечении туберкулеза, а также других заболеваний легких. В недавнем прошлом (советский период) в Абастумани функционировался несколько санаториев, ванное здание, поликлиника, аэросолярий, бассейн, площадь физкультуры, почта, кинотеатр и другие объекты, необходимые для курорта. Однако, после обретения независимости Грузии и в результате известных в стране событий, лечебные учреждения курорта практически перестали функционировать. Реализация проекта восстановления-развития и нового строительства курортной инфраструктуры Абастумани начался с 2018 года. На основе совместного сотрудничества благотворительного фонда «Карту», государственного и частного бизнеса, были выделены достаточно крупные инвестиции, на основе которых восстанавливаются не только лечебно-оздоровительные учреждения, но и весь курорт, в том числе, полное обновление технического оснащения астрофизической обсерватории академии наук Грузии и восстановление в ней научно-исследовательских работ.

В настоящее время, в Абастумани завершаются активные реставрационновосстановительные работы курортной и городской инфраструктуры, что предполагает создание среды, близкой к идеальной с точки зрения экологии. Объекты культурного наследия уже реабилитированы и адаптированы с использованием современных передовых методов. Полностью используется профилактический, оздоровительный и лечебный потенциал минеральных источников. В результате, курорт принимает посетителей круглый год. В частности, в последнее время Абастумани ежегодно посещают в среднем 200 тысяч туристов [13].

Тбилиси один из важнейших бальнеологических курортов страны благодаря разнообразию минеральных вод. Он возник на основе местных термальных сероводородных источников. Находящееся здесь минеральные источники с древних времён использовались в гигиенических и лечебных целях. Многочисленные клинические и экспериментальные исследования подтвердили высокую эффективность тбилисских 
термальных вод. В настоящее время, Тбилисский бальнеологический курорт является медицинским реабилитационным центром, чья минеральная вода оказывает положительное влияние на заболеваниях опорно-двигательного аппарата, желудочнокишечного тракта, периферической нервной системы и на гинекологические системы. Он также используется для лечения легких и умеренных форм гипотонических и гипертонических заболеваний и нарушений обмена веществ. Тем не менее, следует отметить, что столица в мире - редкость, у которой есть целебные воды, один из таких Будапешт, а второй - Тбилиси [14].

Тбилиси издавна известен не только как бальнеологический курорт, но и как административный центр страны и город с богатым историко-культурным наследием. Именно эта популярность привела к значительному увеличению числа посетителей в последние годы, в Тбилиси. В частности, в 2017 году, столицу посетило 50\% посетителей страны, в 2018 году - 52,3\%, а в 2019 году - 54,6\% [1], что соответственно составило 3241215,3767352 и 4218273 посетителей. Таким образом, за последние 3 года, количество посетителей увеличилось на 30,1 процента.

Сочетание бальнеотерапевтических свойств чудесных и живописных курортов Грузии с красотой и разнообразием природы, позволяет им, активно разрабатывать на их основе комплекс SPA и Wellness оздоровительных процедур. В настоящее время, важнейшие лечебно-оздоровительные курорты Грузии уже оснащены услугами SPA медицинскими процедурами для пациентов, что должно способствовать росту туристических потоков и значительному увеличению доходов от туризма. В то же время, обнадеживает то, что Грузия в прошлом сохранила свой имидж успешной туристической страны среди населения бывшего Советского Союза и других соседних стран. Этот важный фактор следует активно использовать в будущем для позиционирования как SPA, так и Wellness туризма.

Приятно отметить, что в Грузии уже работает оздоровительный курорт Биоли (Bioli), которая по своей сущности является новым словом в индустрии отдыха и здоровья. Он основан на последних технологических достижениях современной медицины и расположен в курортной агломерации Тбилиси, к курорту Коджори. В «Биоли», эффективность функционирования организма диагностируется на уровне единицы жизни т.e. клетки. Назначается индивидуальная Wellness программа, что включает как функциональное питание с добавлением лечебных трав, так и антистрессовую физическую активность, соответствующие SPA-терапии и различные процедуры, адаптированные для индивидах. Это, в свою очередь, способствует ранней профилактике заболеваний. Разнообразие эндемичных фиторесурсов и природных ресурсов Грузии, широко используется во всех программах [15].

Несмотря на множество проблем, которые существуют в лечебно-оздоровительном туризме Грузии, можно решительно сказать, что он находится на необратимом пути развития. Об этом свидетельствуют достаточно солидные инвестиции, сделанные в эту сферу, за последние годы, на их базе созданные новые или обновленные и модернизированные лечебно-оздоровительные центры и в целом санатории. Примером этого является медицинский курорт Коджори "Биоли", реконструированный «Цхалтубо спа резорт», обновленные курорты Саирме и Абастумани, также курорт Шекветили с недавно открытым местом размещения премиум класса «Paragraph Resort \& Spa» и другие.

В этой статье, анализируя текущее состояние и перспективы развития туристической индустрии Грузии в том числе 2019 года, нам не избежать испытаний и невзгод в мире и в том числе в нашей стране, вызванных распространением пандемии нового коронавируса 
(Covid-19). В результате вторжения этого невидимого врага, тысячи людей в Грузии временно потеряли здоровье, а некоторые даже погибли. Пандемия сильно ударила по экономике страны, в том числе по туризму. Из-за пандемии, проблемы с безопасностью здоровья человека привели к остановке мобильности путешественников и посетителей, потере рабочих мест, созданных в этом секторе за последние годы и прекращению туристической деятельности.

Следует отметить, что с января 2021 года, во многих странах мира, а в Грузии, в марте начнется процесс вакцинации от коронавируса, что позволит нашей стране окончательно победить этого невидимого врага и параллельно подготовить лечебно-оздоровительные центры и климатические курорты, для принятия миллионы посетителей, которым нужно побороть посткковидный синдром т.е. оздоровление-реабилитация. Прием таких пациентов и высокий уровень обслуживания позволят туристическому сектору в короткие сроки добиться роста доходов и восстановить туристический потенциал. Именно так мы смотрим на это, чтобы превратить кризис в секторе, в новую возможность для развития.

Вывод: Для максимальной активации потенциала лечебно-оздоровительного туризма в Грузии и его дальнейшего развития считаем необходимым:

- Прежде всего, государство, при активном участии правительства, частного сектора и общества, должен обеспечить своевременную вакцинацию населения и всеми мерами способствовать устойчивому, инклюзивному и жизнеспособному развитию туризма.

- Руководству туристического сектора, с помощью правительства, следует добиться широкой рекламы уникальных климатических, бальнеологических и бальнеоклиматических курортов Грузии в ЕС, Северной Америке, на Ближнем Востоке и в странах Азии, с целью привлечения высокооплачиваемых посетителей в страну.

- Разработать государственными органами национальную концепцию развития туризма, в которой на научном уровне будут анализироваться данные о привлечении ресурсов необходимых для развития этой области, с надлежащей оценкой существующего потенциала и определением целевых рынков.

- Государство должно принять активное участие в возрождении и развитии лечебнооздоровительного туризма. Во всех странах, где достигнут серьезный прогресс в этом направлении, государство создавал те необходимые условия, различные формы и механизмы стимулирования, в результате чего, туризм встал на необратимый путь развития.

- Нужно создать постоянно обновляемую всеобъемлющую электронную базу данных о потенциале лечебно-оздоровительного туризма. Он должен предоставлять исчерпывающую информацию об основных медицинских учреждениях и клинических центрах, которая будет доступна для любого жителя мира, через Интернет.

- Учитывая специфику и особенности сферы медицинского туризма, необходимо проводить тренинг-курсы, для персонала, занятого в этой сфере, чтобы они полностью соответствовали требованиям современных международных стандартов. 
- Необходимо улучшить работу транспортной системы - улучшить внутреннюю и межрегиональную дорожную сеть, а также восстановить воздушные и морские рейсы для перевозки и прогулок посетителей.

- Восстановление, реабилитация и развитие существующей устаревшей туристической инфраструктуры, а также строительство новой; Разработка активной рекламной политики в Европе, на Ближнем Востоке, в странах Азии и Северной Америки; Создание сети гостиниц высокого уровня, медицинских центров и др.

- Устроить соответствующую инфраструктуру для культурных мероприятий международного значения, к недавно построенным курортным центрам. В частности, это могут быть: Международный джазфестиваль, Фестиваль туристических фильмов Tourfilm и, конечно же, Международный кинофестиваль, где съезжаются многие всемирно известные люди.

\section{ЛИТЕРАТУРА}

1. Статистический обзор туризма Грузии 2019 года. Национальная администрация туризма Грузии, Тб., 2020

2. Стратегия туризма Грузии - 2025. Национальная администрация туризма Грузии, Тб., 2016

3. Kelle, E, [2013] Medical Tourism Word Health Organization The Global Wellness Tourism Ecome, Global Spa Wellness Summit Global Wellness institute, 2013

4. Верулава Т. Медицинский туризм и Грузия: специфика проблем и рекомендации. «Медицинский туризм: политические, социально-экономические, образовательные и медицинские проблемы в странах Южном Кавказа». Сборник трудов первой научно-практической конференции Университета имени Григола Робакидзе, Батуми, издательство «Дани», Тб., 2016, стр. 100-110

5. Global Wellness Institute (GWI). Wellness Industry Statistics \& Facts. https://globalwellnessinstitute.org/press-room/statistics-and-facts/

6. Гогуадзе Н,. Хускивадзе М., Инновационное развитие оздоровительного туризма на примере энотерапии и ампелотерапии в Грузии. Доклады финалистов конференции - «Перспективы развития туризма в Грузии и мировой опыт», организованной национальной туристической администрацией Грузии. Отдел исследований и планирования национальной администрации туризма Грузии, Тб., 2016, стр. 7-9

7. Кутателадзе Р., Курашвили Г., Беридзе Т., Преимущества Грузии в лечебном туризме, сборник работ $\mathrm{V}$ международной научно-практической конференции факультета туризма БГУ - туризм: экономика и бизнес (5-6 июля 2014 г., БатумиХиханское ущелье), издательство «Меридиани», Тб., 2014, стр. 254-257

8. Пиранашвили М., Гамсахурдиа Т., Медицинский туризм, как продукт устойчивого развития. Материалы первой научно-практической конференции Университета имени Григола Робакидзе - «Медицинский туризм: политические, социальноэкономические, образовательные и медицинские проблемы в странах Южного Кавказа», Батуми, 2016, стр. 70-78

9. Надареишвили Н., Дзидзикашвили Н., Перспективы развития кластеризации медицинского и SPA туризма (на примере Цхалтубо), материалы международной научно-практической конференции факультета туризма БГУ - туризм: экономика и 
бизнес (5-6 июля, 2014, Батумии-Хиханское ущелье, издательство «Меридиани», Тб., 2014, стр. 402-405

10. Отчет о потенциале развития Цхалтубо (базовое исследование). GIPA 2019 год. https://www.tskaltubolag.ge/medias/media/other/42/report-1.pdf

11. Генеральный план туризма для муниципалитета Боржоми. Апрель, 2020. https://www.ge.undp.org/content/georgia/ka/home/library/poverty/borjomi-tourism.html

12. О курорте Саирме. 18 января 2019. http://sairme.com.ge/ka/News/Details/kurort-sairmis--shesaxeb

13. Градостроительные планы Абастумани. Адигенский муниципалитет. Тб., 2019. https://mrdi.gov.ge/pdf/5ea6e36756e6d.pdf

14. Микашавидзе В., Микашавидзе Ж., Туристические ресурсы Грузии. Батумский государственный университет имени Шота Руставели. Батуми, 2017, стр. 143, 151, $154,165,170$

15. Пиранашвили М., Медицинский туризм - приоритеты и возможности на примере BIOLI велнес курорта, сборник трудов VI Международной научно-практической конференции факультета туризма БГУ - туризм: экономика и бизнес (10-11 июля, 2017, Батуми), издательство «Меридиани», 2017, Тб., стр. 221-226

\title{
MEDICAL-RECREATIONAL TOURISM AND PROSPECTS FOR ITS DEVELOPMENT IN GEORGIA
}

\section{Vakhtang Mikashavidze}

Associate Professor, Batumi Shota Rustaveli State University, Georgia.

Email: mikashavidze.vakhtang@bsu.edu.ge

\begin{abstract}
The article, based on the analysis of the activities of the Georgian tourism industry, states that despite the systematic increase in the number of visitors to our country in recent years, revenues from tourism have indeed increased, but the average cost per visitor has only slightly increased; However, the global average is still significantly lower and has a relatively small impact on the socio-economic development of the country.

The paper analyzes the current state of development of medical tourism in Georgia on the basis of economic-statistical materials and sociological research. It also shows the still existing shortcomings and unresolved problems in this area, identified real ways to solve it. Complex issues of sharp growth in tourism revenues have been developed and substantiated. In particular, the restoration and development of balneo and balneo-climatic resorts based on the natural resources of the country and the construction of new medical centers, introduction and implementing of modern healing methods in practice, provision of services to patients with spa and wellness procedures. Admission, treatment-rehabilitation, etc. to high standards for patients with post-covid syndrome. This will make it possible to attract a significant influx of visitors from around the world, including the high-paying ones. The full implementation of these measures provides the basis for optimism for the successful development of health tourism.
\end{abstract}


A Medical-recreational tourism is a relatively new but rapidly evolving direction of the Global Health System. In the last years, the number of patients interested in this particular segment of tourism is systematically increasing in many countries around the world. Moreover, revenues from them are also growing sharply. Countries such as: Israel, Turkey, Switzerland, Italy, India, Indonesia and others, spa and wellness treatments generate billions of dollars in revenue each year. Based on the above-mentioned, it is extremely important for Georgia to share the experience of these countries. In this regard, special attention has been paid recently to the famous balneological and balneo-climatic resorts of our country - Tskaltubo, Borjomi, Sairme, Tbilisi, Abastumani and development of other resorts. At present, spa and wellness medical services are provided in the medical institutions of Georgia, which had an impact on the growth of tourist flows and the increase in revenues from tourism. In the conditions of the modern pandemic, the problem of accelerating the development of medical tourism is becoming even more important. The medical centers of the country should be properly prepared in advance, to host, treat, and serve millions of visitors with debilitating postmodern syndrome to high standards. At the same time, in a short time to achieve an increase in revenue growth in the tourism sector and restore tourism potential. It is this trajectory of the development of the tourism industry that is a prerequisite for overcoming the difficulties created in the sector and turning the crisis into a new opportunity.

Despite the many problems that still exist in the Georgian tourism industry, it can be said that it is on an irreversible path of development. This is indicated by the rather solid investments made in this field in recent years, based on which newly created or renovated and modernized health facilities and resorts. Examples of this are the Kojori Medical Resort "Bioli", the reconstructed "Tskaltubo Spa Resort", the renovated resorts Sairme and Abastumani, the resort „Shekvetili'” the newly opened premium class accommodation.

Keywords: Georgia; Tourism; Industry; Resorts; Medical and recreational; balneoclimatic; SPA; Wellness. 


\section{EDITORIAL BOARD}

Honorary Editors

Archil Prangishvili

Georgian Technical University. Doctor of Technical Sciences. Full Professor.

Avtandil Silagadze

Correspondent committee-man of National Academy of Georgia. Tbilisi University of International Relationships. Doctor of Economical Sciences. Full Professor.

Badri Gechbaia

Batumi Shota Rustaveli State University. Head of Business Administration Department. PhD in Economics,

Associate Professor.

Davit Narmania

Tbilisi State University (TSU), Chair of Management and Administration Department. Professor.

Lamara Qogiauri

Georgian Technical University. Member of Academy of Economical Sciences. Member of New York Academy of Sciences.

Director of first English school named "Nino". Doctor of Economical Sciences. Full Professor.

Lia Eliava

Kutaisi University.Economic expert in the sphere of economy and current events in financial sector.Full Professor.

$\mathrm{PhD}$ in Business Administration.

Liana Ptaschenko

National University «Yuri Kondratyuk Poltava Polytechnic», Doctor of Economical Sciences. Professor.

Nino Didbaridze

Microbiology and Immunology Department. Immunologi Direction. Tbilisi State Medical University. PhD MD.

Paata Koguashvili

Georgian Technical University. Doctor of Economical Sciences. Full Professor. Academician. Member of Georgia Academy of Sciences of Agriculture.

Sergei S. Padalka

Doctor of Historical Sciences, Professor, Senior Researcher at the Department of Contemporary History and Policy at the Institute of History of Ukraine National Academy of Sciences of Ukraine.

Tamar Didbaridze

Tbilisi State Medical University, First University Clinic. PhD in MD.

Zurab Khonelidze

Sokhumi State University. Doctor of Political Sciences. Professor.

\section{Honorary editorial board members:}

Agaheydar Seyfulla Isayev

Azerbaijan State Oil Academy. Doctor of Economical Sciences. Professor.

Jacob Meskhia

Tbilisi State University. Faculty of Economics and Business. Full Professor. 
JANUARY-FEBRUARY VOLUME 40 ISSUE 01

\section{INTERNATIONAL ADVISORY AND EDITORIAL BOARD}

Australia

Shahid Khan

Monash Business School. Sessional Lecturer. PhD in Management.

Vikash Ramiah

UNISA School of Commerce. Associate Professor. PhD in Applied Finance.

\section{Azerbaijan}

Abbas İsmayılov

Azerbaijan State Agricultural University. Associate Professor. PhD in Biology Science.

Almaz Mehdiyeva

Azerbaijan State Oil and Industry University.Associate Professor. PhD in TS

Amir V. Aliyev

Ministry of Health of Azerbaijan Republic Lung Diseases Department. Guba District Central Hospital Head

of Department. PhD of Medicine

Aytekin Hasanova

Azerbaijan Medical University. I Preventive Medicine Faculty. Deputy of Dean. PhD in Medical Biology.

Araz Manucheri-Lalen

Associated Professor, PhD Department of Psychiatry, Azerbaijan Medical University.

Arif M. Mammad-Zada

Baku "Geotechnological problems of oil, gas and chemistry", Scientific Research Institute, Professor, Chief Researcher. DS.

Azer K. Mustafayev

Turan Medical Clinic. Cardiologist. PhD in Medicine. Azerbaijan

Beykas Seyfulla Xidirov

Azerbaijan State Oil and Industrial University. Head of department. Doctor of Economical Sciences

Djamil Alakbarov

A researcher at the Research Institute for Lung Diseases. PhD in medicine. Azerbaijan

Elchin Suleymanov

Baku Engineering University. Associate Professor of Department Finance. PhD in Economy.

Elmira Valiyeva

Azerbaijan State Agrarian University Senior teacher of the Chair of Lnguages.

Elshan Mahmud Hajizade

UNEC. Center of Energy Economics, Director. Doctor of Economic Science. Professor.

Emin Mammadzade

Institute of Economics of ANAS. Economic institute. Phd in Economy. Associate professor.

Farda Imanov

ANAS. Georgrapy Institute. Doctor of Georgraphy Sciences. Professor.

Garib Mamedov

National Academy of Sciences of Azerbaijan Republic. Academician-secretary of the Department of Agrarian Sciences of ANAS,

Academician of ANAS. Doctor of Biolgical Sciences.

Heyder Guliyev

Azerbaijan State Agricultural University. English Teacher. PhD in Philology

Ibrahim Gabibov

Azerbaijan State Oil and Industrial University. Doctor of Technical Sciences. Professor

Jamala Mursalova

Azerbaijan National Academy of Sciences. Genetic Resources Institute. PhD BS.

Lala Bekirova

Azerbaijan State Oil and Industrial University. Azerbaijan National Avation Academy. PhD.TS

Leyla I. Djafarova

Clinic "Medium" Baku. Doctor of Medical Sciences. Professor

Mahmud Hajizade

Sector Director of State Fund for Information Technology Development of the Ministry of Communications and High Technologies of the Republic of Azerbaijan, Ministry of Transport, Communications and High Technologies of the Republic of Azerbaijan.

Naila Quliyeva

Azerbaijan Medical University. Assistant in "Immunology" Program at Paediatrics Diseases Department. Docent and Academic Manager in "Allergology and Immunology" Department.

Rafig Gurbanov

Azerbaijan State Oil and Industrial University. Doctor of Technical Sciences. Professor

Ramiz Gurbanov

Azerbaijan State Oil and Industrial University. Doctor of Technical Sciences. Professor

Ramiz Mammadov

ANAS. Giography Institute. Doctor of Technical Sciences. Professor. Academician.

Rashad G. Abishov

Dental Implant Aesthetic Center Harbor Hospital, Azerbaijan State Doctors Improvement Institute. PhD. Azerbaijan.

Rena Gurbanova

Azerbaijan State Oil and Industrial University. Associate Professor. PhD in Chemistry.

Saadat Sultanova

Azerbaijan Medical University. II Obstetric Gynecology Department. Doctor of Medical Science. Associate Professor. 
Sadagat V. Ibrahimova

Azerbaijan State Oil and Industrial University. Academician Doctor of Economical Sciences. PhD

Sain Safarova

Azerbaijan Medical University. $2^{\text {nd }}$ Internal Medicine Department. Associate Professor. PhD in Medicine.

Samira Mammadova

Sumgayit State University. Senior Teacher of History and its teaching methodology in History Faculty. PhD in History.

Sayyara Ibadullayeva

Institute of Botany. National Academy of Sciences. Professor. PhD in Biological Sciences.

Sevinj Mahmudova

Azerbaijan State Agrarian University. PhD. Researcher.

Tarbiz Nasrulla Aliyev

Innovation Center of National Academy of Azerbaijan Republic. The deputy of director. Doctor of Economical

Sciences.Professor

Tariel Omarov

Azerbaijan Medical University. Department of surgical diseases. PhD in Medicine

Tofig Ahmadov

Azerbaijan State Oil and Industrial University. Doctor of Geology and Mineralogy Sciences. Professor

Tofig Yusif Baharov

Azerbaijan State Oil Company.Scientific Research Institute.Head of department. Doctor of Geology and Mineralogy Sciences

Tofig Samadov

Azerbaijan State Oil and Industrial University. Doctor of Technical Sciences. Professor.

Tubukhanum Gasimzadeh

Azerbaijan National Academy of Sciences. Institute of Dendrology of Azerbaijan NAS. Leading researcher PHD in Biological

Sciences, Associate Professor.

Vusal Ismailov

"Caspian International Hospital". Orthopedics Traumatology Expert. MD. Azerbaijan.

Zakir Aliyev

RAPVHN and MAEP. PhD in Agricultural Sciences, Professor of RAE academician.

Zakir Eminov

ANAS. Giography Institute. Doctor of Georgraphy Sciences. Associate Professor.

Bahrain

Osama Al Mahdi

University of Bahrain, Bahrain Teachers College. Assistant Professor. PhD, Elementary Education and Teaching

\section{Bangladesh}

Muhammad Mahboob Ali

Daffodil International University. Department of Business Administration. Professor.

\section{Belarus}

Tanua Teterinets

Belarusian State University of Agricultural Technology. Doctor of Economical Sciences. Associate Professor.

Vladimir Yanchuk

Belarus State University. Professor. Academy of Postgraduate Education. PhD in Social Psychology.

\section{Bosna \& Hercegovina}

Igor Jurčić

Head of marketing Business group for VSE/SME. Telecommunication Business and Management.

Ratko Pavlovich

University of East Sarajevo. Faculty of Physical Education and Sport. Full Professor. PhD in Sport Sciences.

Brazil

Paulo Cesar Chagas Rodrigues

Federal Institute of Education, Science and Technology of Sao Paulo. Professor. PhD in Mechanical Engineering.

\section{Bulgaria}

Desislava Stoilova

South-West University "Neofit Rilski”. Vice Dean of Faculty of Economics. Associate Professor. PhD in Finance.

Eva Tsvetanova

Tsenov Academy of Economics, Svishtov, Bulgaria Department of Strategic Planning. Head assistant professor. PhD in Economy. Jean-François Rougè

University of technology Sofia.Professor researcher. PhD in Management.

Jean-François Rougè

University of Technology, Sofia. PhD in Business law 
Milena Kirova

Sofia University "St. Kliment Ohridski”. Professor. PhD in Philology.

\section{Croatia}

Dragan Čišić

University of Rijeka. Faculty of Maritime Studies. Full professor. PhD in Logistics, e-business.

\section{Egypt}

Abdelbadeh Salem

Professor at Faculty of Computer and Information Science, Ain Shams University.

Neyara Radwan

King Abdul-Aziz University. Jeddah. KSA. Business Administration Department. Faculty of Economics and Administration. Assistant Professor. Suez Canal University. Mechanical Department. Faculty of Engineering. Assistant Professor.

\section{France}

Michael Schaefer

L’Ässociation 1901 SEPIKE International, Président at SEPIKE International. PhD of Economical Sciences

\section{Georgia}

Anzor G. Abralava

Georgian Technical University. Doctor of Economical Sciences. Full Professor

Dali Sologashvili

State University named Akaki Tsereteli. Doctor of Economical Sciences. Full Professor

Dali Osepashvili

Professor of Journalism and Mass Communication TSU (Tbilisi State University), Head MA Program "Media and New Technology" Davit Tophuria

Tbilisi State Medical University. Head of International Students Academic Department, Associate Professor. PhD in HNA.

Eka Avaliani

International Black Sea University. Associate Professor. PhD in History.

Eka Darchiashvili

Tbilisi State University named after Sv. Grigol Peradze. Assistant of professor. PhD in BA.

Ekaterine Maghlakelidze

The University of Georgia, Associated professor, Business, Economics and Management School.

Enene Menabde-Jobadze

Georgian Technical University. Academical Doctor of Economics.

Eter Bukhnikashvili

Dental clinic "NGM-Innovation Dental". The doctor-stomatologist. PhD in Medicine.

Evgeni Baratashvili

Georgian Technical University. Head of Economic and Business Department. Doctor of Economical Sciences. Full Professor George Jandieri

Georgian Technical University; Chief scientist, Institute of Cybernetics of the Georgian Academy. Full Professor

George Malashkhia

Georgian Technical University. Doctor of Economical Sciences. Full Professor.

Giorgi Kepuladze

Akaki Tsereteli State University, Faculty of Business, Law and Social Sciences, PhD in Economics. Invited teacher.

Gulnara Kiliptari

Tbilisi StateMedical University. Head of ICU department. Associate professor.

lamze Taboridze

Scientific Center of the Humanitarian Educational University, Head, PhD in Medicine. Associate professor.

Irma Makharashvili

Caucasus International University. Dean of Business Faculty. Doctor of Economical Sciences. Full Professor

Ketevan Goletiani

Batumi Navigation Teaching University. Dean of Logistics Faculty.Batumi Shota Rustaveli State University. Doctor TS, Professor.

Larisa Korghanashvili

Tbilisi State University (TSU) named Ivane Javakhishvili. Full Professor

Larisa Takalandze

Sokhumi State University, Faculty of Economic and Business. Doctor of Economic Sciences.

Lia Davitadze

Batumi Shota Rustaveli State University. Higher Education Teaching Professional. PhD in Educational Sciences.

Lia Matchavariani

Tbilisi State University (TSU) named Ivane Javakhishvili. Full Professor, Faculty of Exact \& Natural Sciences (Geography Dep.)

Loid Karchava

Doctor of Business Administration, Association Professor at the Caucasus International University, Editor-in-Chief of the

international Scientific Journal "Akhali Ekonomisti" (The New Economist)

Maia Kapanadze

Georgian State University named Javaxashvili. Doctor of Economical Sciences. Associate Professor.

Maia Matoshvili

Tbilisi State Medical University. The First University Clinic. Dermato-Venereologist. Assistant Professor. PhD in DAPS. 
Mariam Darbaidze

Davit Aghmashenebeli National Defense Academy of Georgia. The Head of Education Division. PhD in Biology.

Mariam Kharaishvili

Ilia State University. Asistent Professor. PhD MD.

Mariam Nanitashvili

Executive Director - Wise Development LTD (Training Centre). Associated Professor at Caucasus University. PhD in Economics Nana Shoniya

State University of Kutaisi named Akakhi Tsereteli. Doctor of Economical Sciences. Full professor

Natia Beridze

LEPL National Environmental Agency of Georgia, Invited Expert at International Relations and PR Division. PhD in Political

Science.

Nelli Sichinava

Akaki Tsereteli State Universiry. Associate. Professor. PhD

Nino Gogokhia

Tbilisi State Medical University. Head of Laboratory the First University Clinic. Professor.

Nino Museridze

GGRC Georgian-German Center for Reproductive Medicine, Owner and Clinical Director. The Doctor of Medicine, Full Professor.

Nino Pirtskhelani

Associated Professor of Department of Molecular and Medical Genetics of Tbilisi State Medical University.

Omari Omarimu

Tbilisi State University named Iv. Javakhishvili. Doctor of Chemical Sciences Professor

Rati Abuladze

St. Andrew the first-called Georgian University of the Patriarchate of Georgia. Faculty of Economics and Eusiness Edministration.

Manager of the Faculty Quality Assurance Office. PhD in Business Administration.

Rusudan Kutateladze

Georgian Technical University. Doctor of Economical Sciences. Full Professor

Rusudan Sujashvili

New Vision University. School of Medicine. Professor,

Simon Nemsadze

Georgian Technical University. Doctor of Technical Sciences. Full Professor

Tamar Giorgadze

Tbilisi State Medical University. Department of Histology, Cytology and Embryology. Assistant Professor.

Tamila Arnania-Kepuladze

Akaki Tsereteli State University. Department of Economics. PhD in Economic.

Tengiz Museliani

Georgian Technical University. Academic Doctor of Technical Sciences. Associate Professor

Timuri Babunashvili

Georgian Business Academy of Science. Doctor of Economical Sciences. Full Professor.

Vladimer Papava

Tbilisi State Medical University. Assistant-Professor. PhD. MD.

Zaira Gudushauri

Georgian-Azerbaijan University named G.Aliyev. Assosiate Professor. PhD. ES.

\section{Germany}

Hans-Juergen Zahorka

Assessor jur., Senior Lecturer (EU and International Law, Institutions and Economy), Chief Editor of "European Union Foreign

Affairs Journal", LIBERTAS - European Institute, Rangendingen

Alexander Dilger

University of Münster. Professor of Business Economics. PhD in Economy.

\section{Greece}

Margarita Kefalaki

Communication Institute of Greece. PhD in Cultural Communication. President of Institute.

\section{Hungary}

Nicasia Picciano

Central European University. Department of International Relations and European Studies.

\section{India}

Federica Farneti

University of Bologna. Department of Sociology and Business Low. Associate Professor. OhD in Economic \& Management.

Prasanta Kumar Mitra

Sikkim Manipal Institute of Medical Sciences. Deptartment of Medical Biotechnology. PhD in Biochemistry.

Samant Shant Priya

Lal Bahadur Shastri Institute of Management, New Delhi, Associate Professor in Philosophy PhD in Marketing 
Sonal Purohit

Jain University, Center for Management Studies, Assistant Professor, PhD in Business Administration, Life Insurance, Privatization. Varadaraj Aravamudhan

Measi Instittue of Management. Associate Professor. PhD in Management.

Iraq

Rana Khudhair Abbas Ahmed

Irag, Baghdad, Alrafidain University College. Lecturer, Global Executive Administrator, Academic coordinator. PhD in Scholar (CS).

Iran

Azadeh Asgari

Asian Economic and Social Society (AESS). Teaching English as a Second Language. PhD

Italy

Simona Epasto

University of Macerata. Department of Political Science, Communication and International Relations. Tenured Assistant Professor in Economic and Political Geography. PhD in Economic and Political Geography

Donatella M. Viola

London School of Economics and Political Science, London, Assistant Professor in Politics and International Relations at the University of Calabria, Italy. PhD in International Relations.

\section{Jordan}

Ahmad Aljaber

President at Gulf University. German Jordan University, Founder / Chairman of the Board. Ph.D in Computer Science

Ahmad Zamil

Middle East University (MEU). Business Administration Dept. Associate Professor. PhD Marketing

Ikhlas Ibrahim Altarawneh

Al-Huessien BinTalal University. Business Department. Full Professor in Human Resource Management.

Asmahan Majed Altaher

Arab Academy for Banking and Financial Sciences. Associate Professor. PhD in Management Information System.

Sadeq AlHamouz

Middle East University (MEU). Head Computer Information Systems. PHD. Computer Science.

Safwan Al Salaimeh

Aqaba University. Sofrware Engineering Department. Information Technology Faculty. Professor. PhD.

\section{Kazakhstan}

Alessandra Clement

Nazarbayev University School of Medicine. MD, GP. Assistant Professor of Medical Practice and Family Medicine

Altinay Pozilova

Sirdarya University. Associated professor. PhD in Pedagogy Science.

Anar Mirazagalieva

Astana Internationl University. Vice-President. PhD in Biology.

Anna Troeglazova

East Kazakhstan State University named Sarsen Amanjolov. PhD

Gulmira Zhurabekova

Marat Ospanov West-Kazakhstan State Medical Academy. Department of Human Anatomy. Associate Professor

Guzel Ishkinina

Ust-Kamenogorsk, Russian Economy University G. Plekhanov, Associate Professor, PhD in Economic science.

Marina Bobireva

West Kazakhstan State Medical University named Marat Ospanov. PhD

Niyazbek Kalimov

Kostanay Agricultural Institution. PhD

Nuriya Kharissova

State University of Karaganda. Associate Professor of Biological Science

Nikolay Kurguzov

State University of Pavlodar named S. Toraygirova. PhD. Professor.

Oleg Komarov

Pavlodar State Pedagogical Institute. Professor of Department of Economics, Law and Philosophy. PhD in Sociology,

Zhanargul Smailova

Head of the Department of Biochemistry and Chemical Disciplines named after MD, professor S.O. Tapbergenova NAC Medical University of city Semey.

\section{Kosovo}

Donat Rexha

Faculty of Economics and Management at the AAB College. Professor. Lecturer. Local Consultant at the UNICEF. 
Libya

Salaheddin Sharif

University of Benghazi, International Conference on Sports Medicine and Fitness, Libyan Football Federation- Benghazi PhD in Medicine (MD)

\section{Latvia}

Tatiana Tambovceva

Latvian Council of Science. Riga Technical University. Assoiate Professor at Riga Technical University

\section{Lithuania}

Agne Simelyte

Vilnius Gediminas Technical University, Associate professor. Phd in Social Sciences (Management)

leva Meidute - Kavaliauskiene

Vilnius Gediminas Technical University. Vice-dean for Scientific Research

Vilma (Kovertaite) Musankoviene

e-Learning Technology Centre. Kaunas University of Technology. PHD

Laura Uturyte

Vilnius Gediminas Technical University (VGTU). Head of Project Manager at PI Gintarine Akademy. PhD in Economy

Loreta (Gedminaitė) Ulvydiene

Professor of Intercultural Communication and Studies of Translation. Vilnius University. PHD

Zhaneta Simanavichienè

Professor, head of Laboratory Business Innovation University of Mykolas Romeris. Honorary consul of Estonia

\section{Macedonia}

Liza Alili Sulejmani

International Balkan University. Head of Banking and Finance department. Assistant Professor. PhD of Economics.

\section{Malaysia}

Anwarul Islam

The Millennium University. Department of Business Administration. Associate Professor.

Kamal Uddin

Millennium University, Department of Business Administration. Associate Professor. PhD in Business Administration.

\section{Morocco}

Mohammed Amine Balambo

Ibn Tufail University, Aix-Marseille University. Free lance. Consultant and Trainer. PhD in Philosophy. Management Sciences Specialty Strategy and Logistics.

\section{Nigeria}

Bhola Khan

Yobe State University, Damaturu. Senior Lecturer and Head, Dept. of Economics. PhD in Economics.

\section{Norway}

Svitlana Holovchuk

$\mathrm{PhD}$ in general pedagogics and history of pedagogics.

\section{Pakistan}

Nawaz Ahmad

The Aga Khan University. Chief Examiner. PhD in Management.

\section{Poland}

Grzegorz Michalski

Wroclaw University of Economics. Faculty of Engineering and Economics. PhD in economics. Assistant professor. Kazimierz Waluch

Pawel Wlodkowic University College in Płock, Assistant Professor at the Faculty of Management. PhD in Economy.

Robert Pawel Suslo

Wroclaw Medical University, Public Health Department, Health Sciences Faculty, Adjunct Professor of Gerontology Unit. PhD MD.

Tadeusz Trocikowski

European Institute for Eastern Studies. PhD in Management Sciences. 
JANUARY-FEBRUARY VOLUME 40 ISSUE 01

Qatar

Mohammed Elgammal

Qatar University. Assistant Professor in Finance. PhD in Finance

Romania

Camelia Florela Voinea

University of Bucharest, Faculty of Political Science, Department of Political Science, International Relations and Security Studies. $\mathrm{PhD}$ in Political Sciences.

Minodora Dobreanu

University of Medicine, Pharmacy, Sciences and Technology of Târgu Mureș. Faculty of Medicine. Professor. PhD in Medicine.

Odette (Buzea) Arhip

Ecological University Bucuresti. Professor at Ecological University. PhD.

\section{Russia}

Alexander A. Sazanov

Leningrad State University named A.S. Pushkin. Doctor of Biological Sciences. Professor

Alexander N. Shendalev

State Educational Institution of Higher Education. Omsk State Transport University. Associate Professor

Andrey Latkov

Stolypin Volga Region Institute of Administration, Ranepa. Sc.D. (Economics), Ph.D. (Politics), professor,

Andrei Popov

Director "ProfConsult Group". Nizhniy Novqorod Region. PhD

Anton Mosalyov

Russian State University of Tourism and Service. Associate Professor

Carol Scott Leonard

Presidential Academy of the National Economy and Public Administration. Vice Rector. PhD, Russian History

Catrin Kolesnikova

Samara Architectural and Constructional University. PhD

Ekaterina Kozina

Siberia State Transportation University. PhD

Elena Klemenova

South Federal University of Russia. Doctor of Pedagogical Sciences. Professor

Galina Kolesnikova

Russian Academy of Natural Sciences and International Academy of Natural History. Taganrog Institute of Management and

Economics. Philologist, Psychologist, PhD

Galina Gudimenko

Orel State Institute of Economics and Trade. Department of History, Philosophy, Advertising and Public Relations.Doctor of Economical Sciences. Professor.

Grigory G. Levkin

Siberian State Automobile and Highway Academy. Omsk State Transport University. PHD of Veterinary Sciences

Gyuzel Ishkinina

Ust-Kamenogorsk affiliation of G. Plekhanov Russian Economy University / Associate Professor, Business, Informatics,

Jurisprudence and General Studies sub-department. PhD in Economic science.

Irina V. Larina

Federal State Educational Institution of Higher Professional Education. Associate Professor

Irina Nekipelova

M.T. Kalashnikov Izhevsk State Technical University. Department of Philosophy. PhD

Larisa Zinovieva

North-Caucasus Federal University. PHD.Pedagogical Science. Associate Professor

Liudmila Denisova

Department Director at Russian State Geological Prospecting University. Associate Professor

Lyalya Jusupowa

Bashkir State Pedagogical University named M.Akmully. PHD Pedagogy Science. Associate Professor

Marina Sirik

Kuban State University. Head of the Department of Criminal Law, Process and Criminalistics of the State Pedagogical University.

$\mathrm{PhD}$ in Legal Sciences.

Marina Volkova

Research Institute of Pedagogy and Psychology. Doctor of Pedagogical Sciences. Professor

Natalia Litneva

Orlov State Institute of Economy and Trade. Volga Branch of The Federal State Budget Educational Institution of Higher

Professional Education

Nikolay N. Efremov

Institute of Humanitarian Research and the Russian Academy of Sciences. Doctor of Philology. Research Associate

Nikolay N. Sentyabrev

Volgograd State Academy of Physical Culture. Doctor of Biological Sciences. Professor. Academician.

Olga Ovsyanik

Plekhanov Russian Economic University, Moscow State Regional University. Doctor in Social Psychology. 
Olga Pavlova

Medical University named Rehabilitation, Doctors and Health, Professor of the Department of Morphology and Pathology, Doctor of biological sciences, physiology

Sergei N. Fedorchenko

Moscow State Regional University of Political Science and Rights. PhD

Sergei A. Ostroumov

Moscow State University. Doctor of Biological Science. Professor

Svetlana Guzenina

Tambov State University named G.R. Derzhavin. PhD in Sociology

Tatiana Kurbatskaya

Kamsk State Engineering - Economical Academy. PhD

Victor F. Stukach

Omsk State Agrarian University. Doctor of Economical Sciences. Professor

Zhanna Glotova

Baltic Federal University named Immanuel Kant, Ph.D., Associate Professor.

\section{Saudi Arabia}

Ikhlas (Ibrahim) Altarawneh

Ibn Rushd College for Management Sciences. PHD Human Resource Development and Management.

Associate Professor in Business Administration

Salim A alghamdi

Taif University. Head of Accounting and Finance Dept. PhD Accounting

\section{Serbia}

Aleksandra Buha

University of Belgrade. Department of toxicology "Akademik Danilo Soldatović", Faculty of Pharmacy

Jane Paunkovic

Faculty for Management, Megatrend University. Full Professor. PhD, Medicine

Jelena Purenovic

University of Kragujevac. Faculty of Technical Sciences Cacak. Assistant Professor. PhD in NM systems.

\section{Sultanate of Oman}

Nithya Ramachandran

Ibra College of Technology. Accounting and Finance Faculty, Department of Business Studies. PhD

Rustom Mamlook

Dhofar University, Department of Electrical and Computer Engineering College of Engineering. PhD in Engineering / Computer Engineering. Professor.

\section{Sweden}

Goran Basic

Lund University. Department of Sociology. PhD in Sociology. Postdoctoral Researcher in Sociology.

Turkey

Fuad Aliew

Gebze Technical University, Department of Electronics Engineering, Faculty of Engineering,Associate professor, PhD in Automation engineering

Mehmet Inan

Turkish Physical Education Teachers Association. Vice president. PhD in Health Sciences, Physical Education and Sport Sciences Muzaffer Sancı

University of Health Sciences. Tepecik Research and Teaching Hospital. Clinics of Gynecology and Obtetrics Department of

Gynecologic Oncologic Surgery. Assocciated Proffesor.

Vugar Djafarov

Medical school at the University of Ondokuzmayıs Turkey. PhD. Turkey.

Yigit Kazancioglu

Izmir University of Economics. Associate Professor, PhDin Business Administration.

UK

Christopher Vasillopulos

Professor of Political Science at Eastern Connecticut State University. PhD in Political Science and Government.

Frances Tsakonas

International Institute for Education Advancement. Ceo \& Founder. PhD in Philosophy.

Georgios Piperopoulos

Northumbria University. Visiting Professor, Faculty of Business and Law Newcastle Business School. PhD Sociology and

Psychology. 
Mahmoud Khalifa

Lecturer at Suez Canal University. Visiting Fellow, School of Social and Political Sciences, University of Lincoln UK. PhD in Social and Political Sciences

Mohammed Elgammal

Qatar University. Assistant Professor. PhD in Finance.

Stephan Thomas Roberts

BP Global Project Organisation. EI\&T Construction Engineer. Azerbaijan Developments. SD 2 Onshore Terminal. Electrical engineer.

\section{Ukraine}

Alina Revtie-Uvarova

National Scientific Center. Institute of Soil Structure and Agrochemistry named Sokolovski. Senior Researcher of the Laboratory, performing part-time duties of the head of this laboratory.

Alla Oleksyuk-Nexhames

Lviv University of Medicine. Neurologyst at pedagog, pryvaty refleksoterapy. MD PD.

Anna Kozlovska

Ukrainian Academy of Banking of the National Bank of Ukraine. Associate Professor. PhD in Ecomomic.

Bogdan Storokha

Poltava State Pedagogical University. PhD

Dmytro Horilyk

Head of the Council, at Pharmaceutical Education \& Research Center. PhD in Medicine.

Galina Kuzmenko

Central Ukrainian National Technical University, Department of Audit and Taxation, Associate Professor.PhD in Economiy.

Galina Lopushniak

Kyiv National Economic University named after Vadym Hetman. PhD. Doctor of Economic Sciences, Professor.

Hanna Huliaieva

Institute of Microbiology and Virology, NASU, department of phytopatogenic bacteria. The senior research fellow, PhD in Biology. Hanna Komarnytska

Ivan Franko National University of Lviv, Head of the Department of Economics and Management, Faculty of Finance and Business Management, Ph.D. in Economics, Associate Professor.

Iryna Skrypchenko

Prydniprovsk State Academy of Physical Culture and Sports. Department of Water Sports. Associate Professor. PhD in Physical Education and Sport.

Katerina Yagelskaya

Donetsk National Technical University. PhD

Larysa Kapranova

State Higher Educational Institution «Priazovskyi State Technical University» Head of the Department of Economic Theory and Entrepreneurship, Associate Professor, PhD in Economy,

Lesia Baranovskaya

National Technical University of Ukraine "Kyiv Polytechnic Institute", PhD, Associate Professor.

Liliya Roman

Department of Social Sciences and Ukrainian Studies of the Bukovinian State Medical University. Associate professor, PhD in Philology,

Liudmyla Fylypovych

Vice-president of Ukrainian Association of Researchers of Religion (UARR), H.S. Skovoroda Institute of Philosophy of NASU.

Doctor of philosophical sciences. Professor

Lyudmyla Svistun

Poltava national technical Yuri Kondratyuk University. Department of Finance and Banking. Associated Professor.

Mixail M. Bogdan

Institute of Microbiology and Virology, NASU, department of Plant of viruses. PhD in Agricultural Sciences.

Nataliya Bezrukova

Yuri Kondratyuk National Technical University. Associate Professor, PhD in Economic.

Oleksandr Voznyak

Hospital "Feofaniya". Kyiv. Head of Neureosurgical Centre. Associated Professor

Oleksandra Kononova

Prydniprovska State Academy of Civil Engineering and Architecture (PSACIA), Assoc.professor of Accounting, Economics and

Human Resources Management department. PhD. in Economic Science.

Oleksandr Levchenko

Central Ukrainian National Technical University, Kropyvnytskyi. Vice-Rector for Scientific Activities. Professor.

Olena Aleksandrova

Borys Grinchenko Kyiv University, Dean of the Faculty of History and Philosophy. Doctor of Philosophical Sciences, Professor.

Olena Cherniavska

Poltava University of Economics and Trade, Doctor of Economical Sciences. Professor

Olga F. Gold

Odessa National University named I.I. Mechnikov. Odessa pedagogical college. PhD

Olga I. Gonchar

Khmelnytsky National University, Economics of Enterprise and Entrepreneurship, Doctor of Economic Sciences, Professor.

Roman Dodonov

Head of the Philosophy Department. Borys Grinchenko Kyiv University. Doctor of philosophical sciences. Professor. 
Roman Lysyuk

Assistant Professor at Pharmacognosy and Botany Department at Danylo Halytsky Lviv National Medical University.

Stanislav Goloborodko

Doctor of Agricultural Sciences, Senior Researcher. Institute of Agricultural Technologies of Irrigated Agriculture of the National

Academy of Agrarian Sciences of Ukraine

Svetlana Dubova

Kyiv National University of Construction and Architecture. Department of Urban Construction. Associate Professor. PhD in TS.

Kyiv Cooperative Institute of Business and Law

Tetiana Kaminska

Kyiv Cooperative Institute of Business and Law. Rector. Doctor of Science in Economics.

Valentina Drozd

State Scientific Research Institute of the Ministry of Internal Affairs of Ukraine. Doctor of Law, Associate Professor, Senior

Researcher.

Vasyl Klymenko

Central Ukrainian National Technical University. Department of Electrical Systems and Energy Management. Doctor TS. Professor.

Victoriya Lykova

Zaporizhzhya National University, PhD of History

Victor P. Mironenko

Doctor of Architecture, professor of department "Design of architectural environment", Dean of the Faculty of Architecture of

Kharkov National University of Construction and Architecture (KNUCA), member of the Ukrainian Academy of Architecture

Vita Tytarenko

H.S. Skovoroda Institute of Philosopy, National Academy of Sciences. Professor at the Department of Philosophy.

Yuliia Mytrokhina

Donetsk National University of Economics and Trade named after Mykhaylo Tugan-Baranovsky., PhD in Marketing and

Management. Associate Professor

Yulija M. Popova

Poltava National Technical University named Yuri Kondratyuk. PhD in Ecomomic. Assiciated professor

\section{Crimea}

Lienara Adzhyieva

V.I. Vernadsky Crimean Federal University, Yevpatoriya Institute of Social Sciences (branch). PhD of History. Associate Professor Oksana Usatenko

V.I. Vernadsky Crimean Federal University. Academy of Humanities and Education (branch). PhD of Psychology.

Associate Professor.

Oleg Shevchenko

V.I. Vernadsky Crimean Federal University, Humanities and Education Science Academy (branch), Associate Professor. PhD in

Social Philosophy

Tatiana Scriabina

V.I. Vernadsky Crimean Federal University, Yevpatoriya Institute of Social Sciences (filial branch). PhD of Pedagogy.

Associate Professor

\section{United Arab Emirates}

Ashok Dubey

Emirates Institute for Banking \& Financial Studies, senior faculty. Chairperson of Academic Research Committee of EIBFS.

$\mathrm{PhD}$ in Economics

Maryam Johari Shirazi

Faculty of Management and HRM. PhD in HRM. OIMC group CEO.

USA

Ahmet S. Yayla

Adjunct Professor, George Mason University, the Department of Criminology, Law and Society \& Deputy Director, International

Center for the Study of Violent Extremism (ICSVE), PhD in Criminal Justice and Information Science

Carol Scott Leonard

Presidential Academy of the National Economy and Pubic Administration. National Research University - Higher School of

Economics. Russian Federation

Christine Sixta Rinehart

Academic Affairs at University of South Carolina Palmetto College. Assistant Professor of Political Science. Ph.D. Political Science Cynthia Buckley

Professor of Sociology at University of Illinois. Urbana-Champaign. Sociological Research

Medani P. Bhandari

Akamai University. Associate professor. Ph.D. in Sociology.

Mikhail Z. Vaynshteyn

Lecturing in informal associations and the publication of scientific articles on the Internet. Participation in research seminars in the

"SLU University" and "Washington University", Saint Louis

Nicolai Panikov

Lecturer at Tufts University. Harvard School of Public Health. PhD/DSci, Microbiology 
Rose Berkun

State University of New York at Buffalo. Assistant Professor of Anesthesiology, PhD. MD

Tahir Kibriya

Director technical / senior engineering manager. Black \& Veatch Corporation, Overland Park. PhD Civil Engineering

Yahya Kamalipour

Dept. of Journalism and Mass Communication North Carolina A\&T State University Greensboro, North Ca. Professor and Chair

Department of Journalism and Mass Communication North Carolina A\&T State University. PhD

Wael Al-Husami

Lahey Hospital \& Medical Center, Nardone Medical Associate, Alkhaldi Hospital, Medical Doctor, International Health, MD, FACC FACP

\section{Uruguay}

Gerardo Prieto Blanco

Universidad de la República. Economist, Associate Professor. Montevideo.

\section{Uzbekistan}

Guzel Kutlieva

Institute of Microbiology. Senior Researcher. PhD in BS.

Khurshida Narbaeva

Institute of Microbiology, Academy of Sciences Republic of Uzbekistan, Doctor of biological sciences.

Shaklo Miralimova

Academy of Science. Institute of Microbiology. Doctor of Biology Sciences. PhD in BS.

Shukhrat Yovkochev

Tashkent State Institute of Oriental Stadies. Full professor. PhD in political sciences. 
NGO International Center for Research, Education \& Training (Estonia, Tallinn) is publishing scientific papers of scientists on Website and in Referred Journals with subjects which are mentioned below:

(C) The Baltic Scientific Journals

ISSN: 2613-5817; E-ISSN: 2613-5825; UDC: 0 (0.034);

DOI PREFIX: 10.36962/PIRETC

Proceeding of The International Research Education \& Training Center.

http://sc-media.org/piretc/

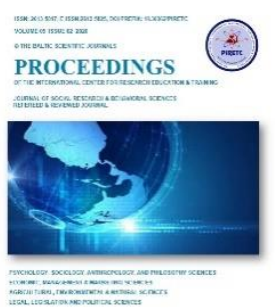

ISSN: 2674-4562, E-ISSN: 2674-4597, UDC: 620.9 (051) (0.034);

DOI PREFIX: 10.36962/ENECO

Proceedings of Energy Economic Research Center. ENECO

http://sc-media.org/eneco/

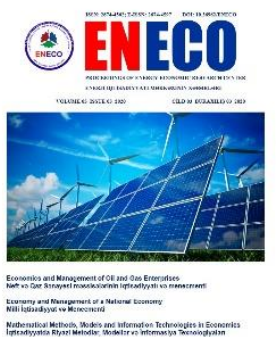

ISSN: 1609-1620, E-ISSN: 2674-5224; UDC: 62 (051) (0.034);

DOI PREFIX: 10.36962/PAHTEI

Proceedings of Azerbaijan High Technical Educational Institutions. PAHTEI http://sc-media.org/pahtei/

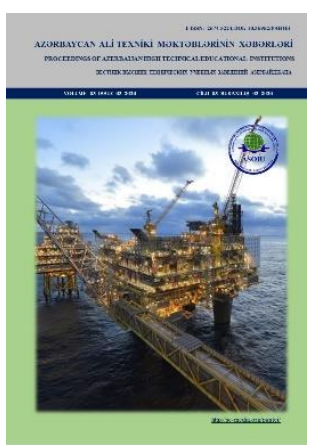


ISSN: 2663-8770, E-ISSN: 2733-2055; UDC:

DOI PREFIX: 10.36962/ETM

ETM Equipment, Technologies, Materials

http://sc-media.org/etm/

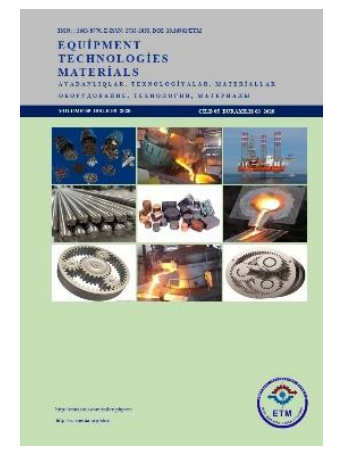

ISSN: 2733-2713; E-ISSN: 2733-2721; UDC:

DOI PREFIX: 10.36962/SWD

SOCIO WORLD-SOCIAL RESEARCH \& BEHAVIORAL SCIENCES

http://sc-media.org/swd/

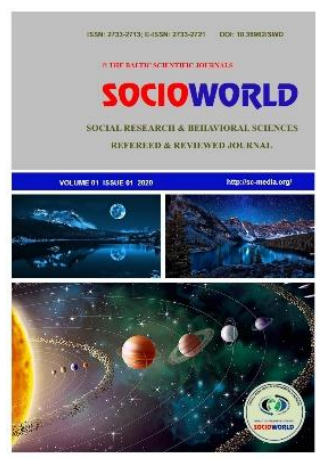

Society of Azerbaijanis living in Georgia. NGO. (Georgia, Tbilisi) is publishing scientific papers of scientists on Website and in Referred Journals with subjects which are mentioned below:

(c) Southern Caucasus Scientific Journals

ISSN: 1987-6521, E-ISSN: 2346-7541; UDC: 551.46(0510.4)

DOI PREFIX: 10.36962/GBSSJAR, IF-1.05

Gulustan-Black Sea Scientific Journal of Academic Research http://sc-media.org/gulustan-bssjar/

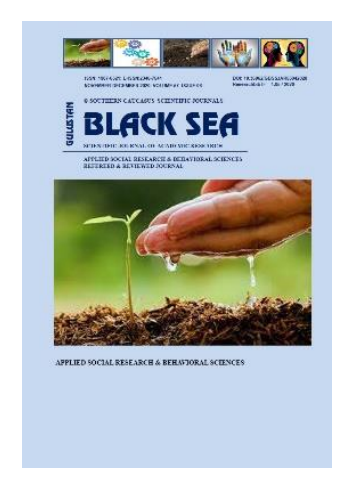


ISSN: 2346-8068; E-ISSN: 2346-8181;

DOI PREFIX: 10.36962/ALISJMSC

Ambiance in Life-International Scientific Journal in Medicine of Southern Caucasus.

http://sc-media.org/ambiance-in-life-isjmsc/

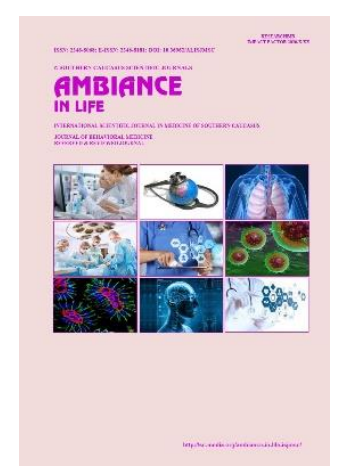

Representation of the International Diaspora Center of Azerbaijan in Georgia. NGO. (Georgia Tbilisi) is publishing scientific papers of scientists on Website and in Referred Journals with subjects which are mentioned below:

\section{(C) Southern Caucasus Scientific Journals}

ISSN: 2298-0946, E-ISSN: 1987-6114; UDC: 3/k-144

DOI PREFIX: 10.36962/CESAJSC

The Caucasus-Economic and Social Analysis Journal of Southern Caucasus

http://sc-media.org/the-caucasus-sjarsc/

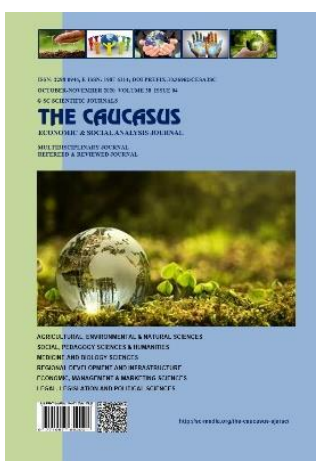


NOTES

\begin{tabular}{|l|}
\hline \\
\hline \\
\hline \\
\hline \\
\hline \\
\hline \\
\hline \\
\hline \\
\hline \\
\hline \\
\hline \\
\hline \\
\hline
\end{tabular}




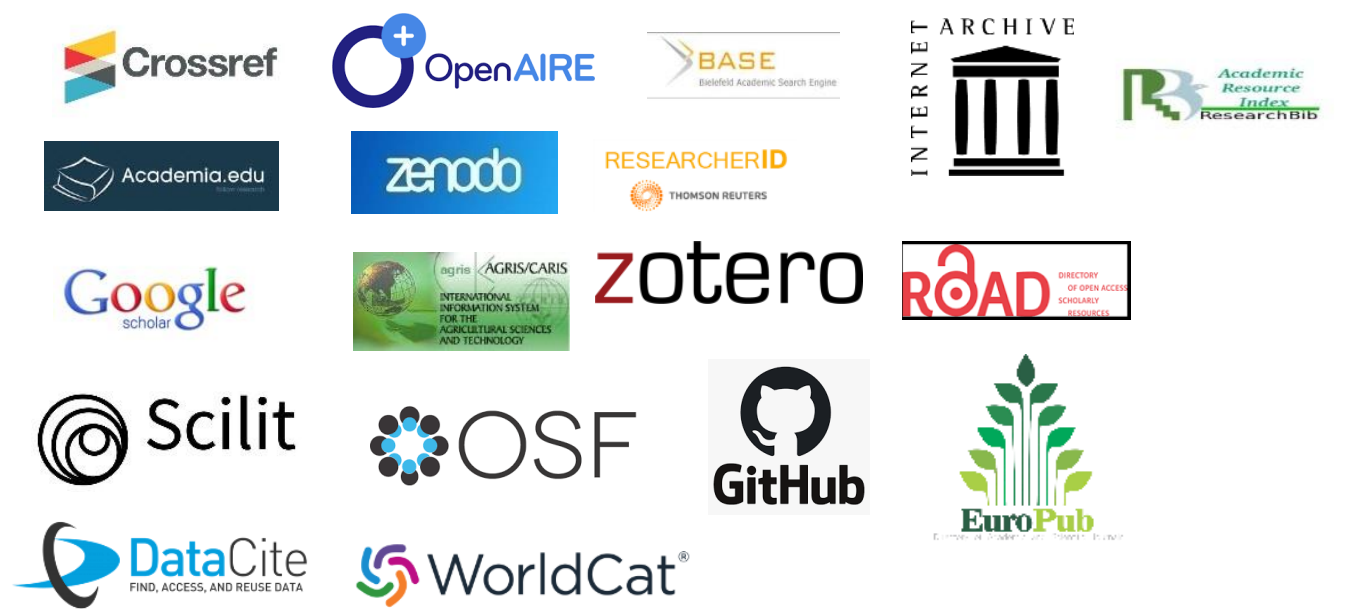

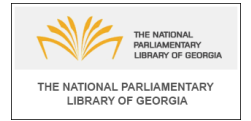

GRID

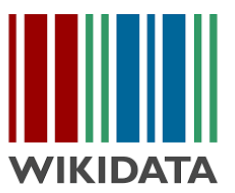

2. НАУЧНАЯ ЭЛЕКТРОННАЯ

LIBRARY.RU

*isni
SHERPA

ROMEO

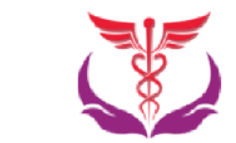

ดSPEnDOS-nCADEmY ITD
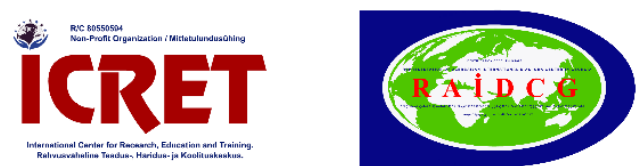

ISSN: 1987-6521; E-ISSN:2346-7541; DOI prefix: 10.36962/CESAJSC

CPublisher: LTD Aspendos International Academy of Medical and Social Sciences. (UK, London).

Director and shareholder: Alexandra Cuco. Lawyer. Portugal.

Deputy and shareholder: Namig Isazade. Full Professor.

(CEditorial office: 71-75 Shelton Street, Covent Garden, London, WC2H 9JQ, UK.

CTypography: LTD Aspendos International Academy of Medical and Social Sciences. (UK, London).

Registered address: 71-75 Shelton Street, Covent Garden, London, WC2H 9JQ, UK.

Telephones: +994552417012; +994518648894

Website: http://sc-media.org/

E-mail: gulustanbssjar@gmaill.com, sc.mediagroup2017@gmail.com; caucasusblacksea@gmail.com

CPublisher: Representation of Azerbaijan International Diaspora Center in Georgia. SCS Journals CEditorial office: 0165 Georgia. Marneuli municipality. Village Takalo.

CTypography: Representation of Azerbaijan International Diaspora Center in Georgia. SCS Journals.

Registered address: 0165 Georgia. Marneuli municipality. Village Takalo.

Telephones: +994552417012; +994518648894.

Website: http://sc-media.org/

E-mail: gulustanbssjar@gmaill.com,sc.mediagroup2017@gmail.com; caucasusblacksea@gmail.com 


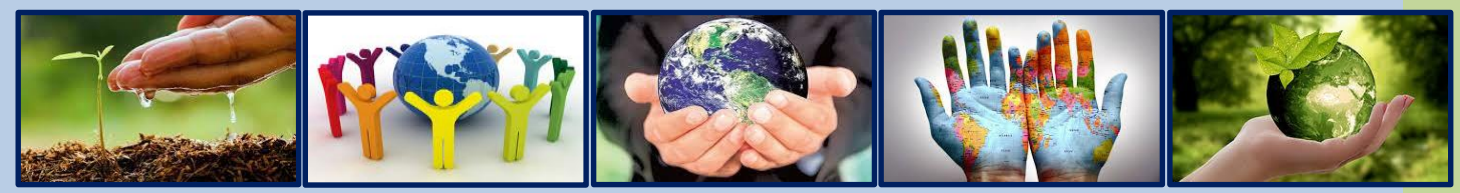

ISSN: 2298-0946, E-ISSN: 1987-6114; DOI PREFIX:10.36962/CESAJSC

JANUARY-FEBRUARY 2021 VOLUME 40 ISSUE 01

(C) SC SCIENTIFIC JOURNALS

\section{THE CAUCASUS}

ECONOMIC \& SOCIAL ANALYSIS JOURNAL OF SOUTHERN CAUCASUS

MULTIDISCIPLINARY JOURNAL

REFEREED \& REVIEWED JOURNAL

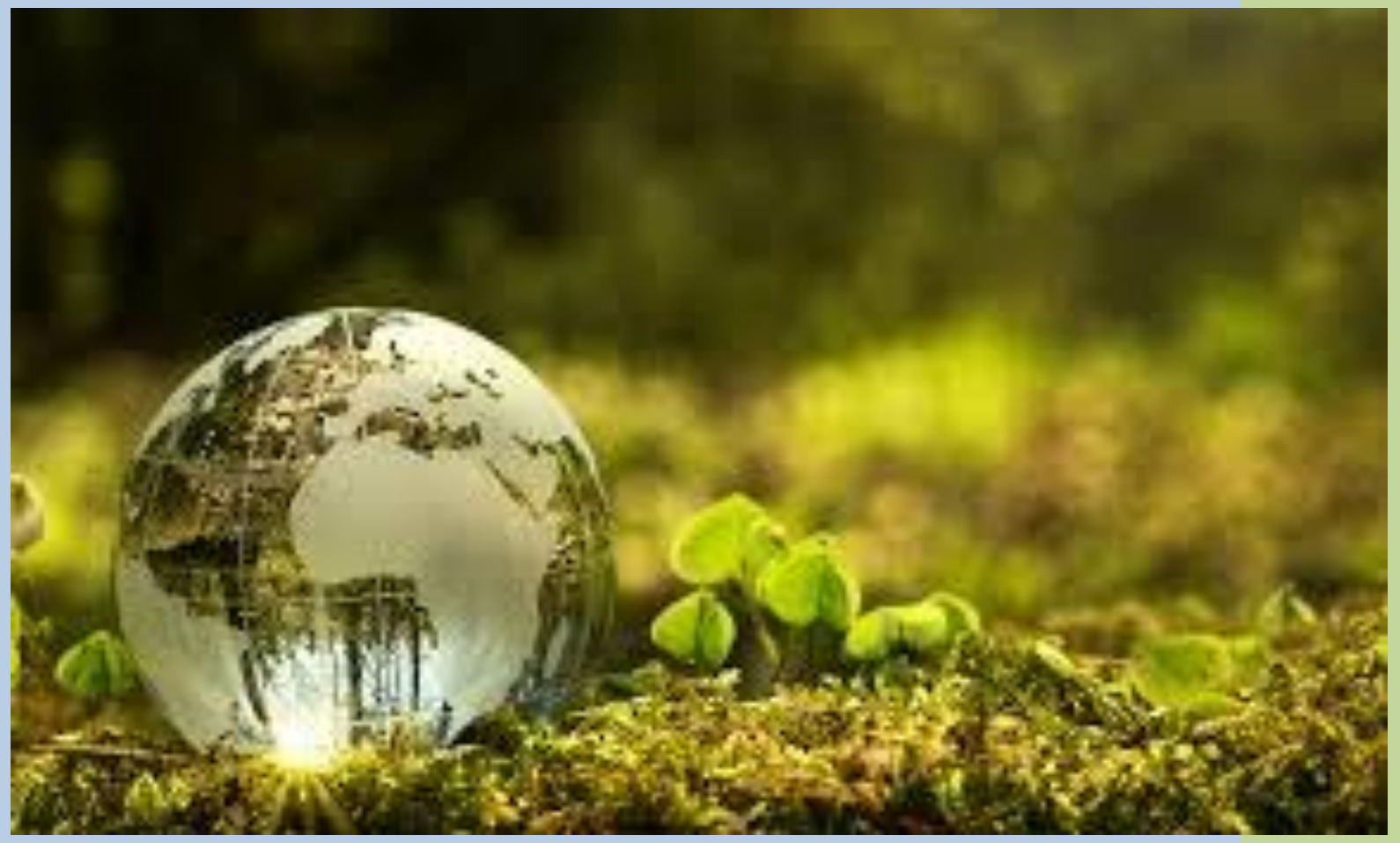

AGRICULTURAL, ENVIRONMENTAL \& NATURAL SCIENCES

SOCIAL, PEDAGOGY SCIENCES \& HUMANITIES

MEDICINE AND BIOLOGY SCIENCES

REGIONAL DEVELOPMENT AND INFRASTRUCTURE

ECONOMIC, MANAGEMENT \& MARKETING SCIENCES

LEGAL, LEGISLATION AND POLITICAL SCIENCES 